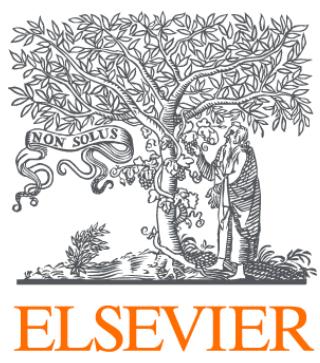

Since January 2020 Elsevier has created a COVID-19 resource centre with free information in English and Mandarin on the novel coronavirus COVID-

19. The COVID-19 resource centre is hosted on Elsevier Connect, the company's public news and information website.

Elsevier hereby grants permission to make all its COVID-19-related research that is available on the COVID-19 resource centre - including this research content - immediately available in PubMed Central and other publicly funded repositories, such as the WHO COVID database with rights for unrestricted research re-use and analyses in any form or by any means with acknowledgement of the original source. These permissions are granted for free by Elsevier for as long as the COVID-19 resource centre remains active. 


\section{MASTER AUTHOR INDEX}

Aasa, R., see J.C. Cox

Abdulaev, N.G., see Yu.A. Ovchinnikov

Abillon, E., see J. Vičar

Abramovitz, E., see H. Rahamimoff

Abreu, H., see D.S Seidl

Abuknesha, R, see D. Exley

Acher, R., see M.T. Chauvet

Adamkiewicz, J., Z. Veres-Molnár and W. Büttner, Mapping of the EcoRI B fragment-specific early mRNA species of adenovirus type 2

Aerts, G., see H. Gorissen

Aerts, G., see H. Gorissen

Agarwal, M.K. and M. Philippe, Thermal activation of steroid binding principle in commercial bovine serum albumin

Agol, V.I., see Yu.V. Svitkin

Ahkong, Q.F., A.M.J. Blow, G.M. Botham, J.M. Launder, S.J. Quirk and J.A. Lucy, Proteinases and cell fusion

Ahmadi, B. and P.T. Speakman, Suberimidate crosslinking shows that a rodshaped, low cystine, high helix protein prepared by limited proteolysis of reduced wool has four protein chains

Aitio, M.-L., K. Yamashita and J.R. Dawson, The electrophoretic heterogeneity of carcinoembryonic antigen: an immunochemical analysis

Akasaka, K., see A. Yamada

Akaska, K., M. Konrad and R.S. Goody, Selective spin diffusion. A novel method for studying motional properties of biopolymers in solution

Åkerlund, H.-E., see P. Gräber

Ảkerman, K.E.O., Charge transfer during valinomycin-induced $\mathrm{Ca}^{2+}$ uptake in rat liver mitochondria

Åkerman, K.E.O. and M.K.F. Wikström, $\left(\mathrm{Ca}^{2+}+\mathrm{Mg}^{2+}\right)$-stimulated ATPase activity of rabbit myometrium plasma membrane is blocked by oxytocin

Åkerman, K.E.O. and C.H.J. Wolff, Charge transfer during $\mathrm{Ca}^{2+}$ uptake by rabbit skeletal muscle sarcoplasmic reticulum vesicles as measured with oxanol VI

Åkesson, B., Autoregulation of phospholipid $N$-methylation by the membrane phosphoatidylethanolamine content

Åkesson, B., see P. Elias

Akkerman, J.W.N., H. Holmsen and H.A. Driver, Platelet aggregation and $\mathrm{Ca}^{2+}$ secretion are independent of simultaneous ATP production

Alberte, R.S. and J.P. Thornber, A rapid procedure for isolating the photosystem 1 reaction center in a highly enriched form

Albracht, S.P.J., see H.-G. Heidrich

Alonso, A., Ch. Louis, C.N. Flytzanis and C.E. Sekeris, Distribution of coding sequences within the nuclear HnRNA protein complexes

Alonso, A., see C. Flytzanis

Alstein, M., see Z. Vogel

Altendorf, K., see L. Wieczorek

Altmann, M., H. Koischwitz, J. Salnikow and H. Kleinkauf, (3,3'-Leu)-gramicidin S formation by gramicidin synthetase

Altruda, F., see A. Ceccarelli

Alves, M.J.M., J.F. da Silveira, C.H.R. de Paiva, C.T. Tanaka and W. Colli, Evidence for the plasma membrane localization of carbohydrate containing macromolecules from epimastigote forms of Trypanosoma cruzi

Ammerer, G. and H. Ruis, Cell-free synthesis of Saccharomyces cerevisiae catalase $T$

Amselem, S., see Y. Barenholz

Anderson, J.M., J.C. Waldron and S.W. Thorne, Chlorophyll-protein complexes of spinach and barley thylakoids. Spectral characterization of six complexes resolved by an improved electrophoretic procedure

Anderson, R.E., see P.A. Dudley

93 (1978) 157

100 (1979) 219

97 (1979) 275

92 (1978) 163

92 (1978) 245

91 (1978) 162

98 (1979) 37

94 (1978) 199

96 (1978) 64

100 (1979) 281

93 (1978) 129

96 (1978) 211

95 (1978) 147

94 (1978) 365

93 (1978) 29

93 (1978) 16

96 (1978) 287

96 (1978) 233

93 (1978) 293

97 (1979) 283

100 (1979) 291

92 (1978) 177

98 (1979) 145

100 (1979) 286

91 (1978) 126

95 (1978) 314

93 (1978) 351

96 (1978) 201

98 (1979) 44

98 (1979) 233

93 (1978) 247

93 (1978) 348

99 (1979) 81

99 (1979) 242

99 (1979) 210

92 (1978) 227

95 (1978) 57 
Anderson, W.M., see S.R. Earle

Anderton, D.H., M. Ayers and R. Thorpe, Neurofilaments from mammalian central and peripheral nerve share certain polypeptides

André, C,M., see J.G. Lewis

Andries, M. and R. de Wachter, The reaction of an organomercury compound with a nucleoside phosphorothioate. Implications for the prospect of electron microscopic nucleic acid sequencing

Angal, S. and P.D.G. Dean, The use of immobilized Cibacron Blue in plasma fractionation

Ansari, A.A., see B. Pegoraro

Anstee, D.J., see T. Maeda

Antolini, R. and G. Menestrina, Ion conductivity of the open keyhole limpet hemocyanin channel

Antonini, E., see J.-E. Norne

Antonini, E., see H.A. Kuiper

Antonini, E., see S. Stefanini

Antonov, I.V., see A.G. Pavlovsky

Anzenbacher, P., see J. Hudeček

Aoyagi, H., see A. Yasutake

Aphanasenko, G.A., S.M. Dudkin, L.B. Kaminir, I.B. Leshchinskaya and E.S. Severin, Primary structure of ribonuclease from Bacillus-intermedius $7 \mathbf{P}$

Araki, T, Release of cholesterol-enriched microvesicles from human erythrocytes caused by hypertonic saline at low temperatures

Araki, Y., see S. Kawagishi

Archer, S.A., E.D.T. Atkins and K.H. Gardner, X-ray diffraction results from the extracellular fungal glucan secreted by Monilinia fructigena

Arefiev, I.M., see I.G: Kharitonenkov

Arendes, J., see W.E.G. Müller

Argos, P., M. Hanei and R.M. Garavito, The Chou-Fasman secondary structure prediction method with an extended data base

Ariano, H., see K. Sigrist-Nelson

Ariga, T., see T. Miyatake

Arlaud, G.J., see R.B. Sim

Arnaud, J., O. Nobili and J. Boyer, Characterization of a monoester lipase active as membrane-bound enzyme in rat erythrocytes

Amon, D.I., see T. Hiyama

Arrio-Dupont, M., see D. Vergé

Arutjunjan, A.M. Yu.A. Kamensky, E. Milgröm, S. Surkov, A.A. Konstantinov and Yu.A. Sharonov, Is mitochondria cytochrome $b-566 / 558$ a single hemoprotein or two individual components? A magnetic circular dichroism study

Asada, K., see S. Kanematsu

Asselbergs, F.A.M., W.H.M. Peters, W.J. van Venrooij and H. Bloemendal, Cap analogues do not inhibit mRNA translation in Xenopus laevis oocytes

Atkins, E.D.T., see S.A. Archer

Atlas, D., D. Yaffe and E. Skutelsky, Ultrastructural probing of $\beta$-adrenoreceptors on cell surfaces

Atsumi, T., see T. Miyatake

Aubel-Sadron, G., see M. Capri

Auclair, C., see M. Torres

Ausiello, C., see M. Tomasi

Averame, M.M., see G. Nanni

Avigliano, L., A. Desideri, S. Urbanelli, B. Mondovi and A. Marchesini, Removal of non-blue copper from ascorbate oxidase

Avron, M., see C. Vinkler

Avron, M., Energy transduction in photophosphorylation

Axberg, T., see P. Elias

Ayad, S.R. and R.J. Hughes, Solubilized prostaglandin binding components

Ayers, M., see D.H. Anderton

Azoulay, E., see G. Giordano

Azzar, G. and R. Got, Isolement par chromatographie d'affinité de fractions membranaires spécialisees, à partir de microsomes d'hépatocytes de chat
91 (1978) 21

96 (1978) 159

92 (1978) 211

97 (1979) 69

96 (1978) 346

95 (1978) 371

98 (1979) 157

$100(1979) 377$

94 (1978) 410

99 (1979) 317

100 (1979) 296

92 (1978) 258

$100(1979) 379$

100 (1979) 241

$97(1979) \quad 77$

97 (1979) 237

97 (1979) 20

92 (1978) 343

$96(1978) 120$

94 (1978) 47

93 (1978) 19

95 (1978) 140

97 (1979) 257

97 (1979) 111

99 (1979) 43

98 (1979) 381

100 (1979) 265

95 (1978) 40

$91(1978) 94$

94 (1978) 195

92 (1978) 343

95 (1978) 173

97 (1979) 257

91 (1978) 329

97 (1979) 50

94 (1978) 253

93 (1978) 242

100 (1979) 318

96 (1978) 129

96 (1978) 223

98 (1979) 145

95 (1978) 165

96 (1978) 159

95 (1978) 290

$96(1978) 164$ 
Azzi, A., see R. Bisson

Azzi, A., see K. Sigrist-Nelson

Azzone, G.F., F. Bortolotto, A. Zanotti and L. Pregnolato, Induction of electroneutral exchanges of $\mathrm{H}^{+}$and $\mathrm{K}^{+}$in rat liver mitochondria

Azzone, G.F., A. Zanotti, R. Colonna and L. Pregnolato, Induction of electroneutral exchanges of $\mathrm{H}^{+}$with $\mathrm{Na}^{+}$, divalent and organic cations in rat liver mitochondria

Bababunmi, E.A., see O.O. Olorunsugo

Babcock, G.T. and C.K. Chang, Oxygen binding to ferrous heme $a$ and a synthetic analog

Baccarini Melandri, A., see B.A. Melandri

Baccarini Melandri, A., see S. de Chadarevjan

Bach, D., see J.C. Gómez-Fernández

Back, U., see T.C. Bøg-Hansen

Bäckström, D., see T. Ljones

Bäckström, D., see H.-G. Heidrich

Baddiley, J., see F.M. Roberts

Bader, C.A., see J.-D. Monet

Bagchi, B., see S. Basu

Bailey, A.J., see N.D. Light

Bailey, A.J., T.J. Sims, V.C. Duance and N.D. Light, Partial characterization of a second basement membrane collagen in human placenta. Evidence for the existence of two type IV collagen molecules

Bakka, A., see P.J. Sadler

Bakken, A.M., M. Farstad and R. Berge, The formation of alkyl palmitate by rat liver microsomes

Bakker-Steeneveld, H., see $\mathbf{K}$. van der Laken

Balaram, P., see R. Narayanan

Balaram, P., see R. Nagaraj

Balaram, P., see Ch. Pulla Rao

Ballesta, J.P.G., see C. Bernabeu

Baltscheffsky, M., see C.L. Bashford

Banerjee, A.C. and B. Bhattacharyya, Colcemid and colchicine binding to tubulin: Similarity and dissimilarity

Banerjee, S.K., see I.L. Flink

Bar, A., see S. Edelstein

Barber, J. and G.F.W. Searle, Cation induced increase in chlorophyll fluorescense yield and the effect of electrical charge

Barchi, R.L., see J.B. Weigele

Barchi, R.L., see J.B. Weigele

Barciszewska, J., see A. Joachimiak

Barciszewska, M., see A. Joachimiak

Barel, A.O., see V. Versée

Barenholz, Y., S. Amselem and D. Lichtenberg, A new method for preparation of phospholipid vesicles (liposomes)-French press

Barlas, M., H. Ruis and A. Sledziewski, Synthesis of catalase T under anaerobic conditions in a mutant of Saccharomyces cerevisiae

Barlow, C. and M. Erecinśka, Orientation of the NO ligand of cytochrome $a_{3}$ in nitrosyl cytochrome $c$ oxidase

Barnard, E.A., see I. Silman

Barnard, P., see W. Hoffmann

Barranger, J.A., see C.J. Steer

Bartels, M., see P. Ludwig

Barthelemy-Clavey, V., see M. Capri

Bartolotto, F., see G.F. Azzone

Bârzu, O., see L.D. Ngoc

Bashford, C.L., M. Baltscheffsky and R.C. Prince, The phosphate potential and $\mathrm{H}^{+}$/ATP ratio in Rhodospirillum rubrum

Basset, P., see C. Froissart

Bassir, O., see O.O. Olorunsogo

Basu, S. and B. Bagchi, Mutation in Escherichia coli during photodynamic inactivation and subsequent holding in buffer
92 (1978) 219

95 (1978) 140

$96(1978) 135$

96 (1978) 141

97 (1979) 279

97 (1979) 358

95 (1978) 130

97 (1979) 293

98 (1979) 224

93 (1978) 86

92 (1978) 81

95 (1978) 314

97 (1979) 211

96 (1978) 79

96 (1978) 26

97 (1979) 183

99 (1979) 361

94 (1978) 315

99 (1979) 47

100 (1979) 230

93 (1978) 38

96 (1978) 277

100 (1979) 244

99 (1979) 251

97 (1979) 55

99 (1979) 333

94 (1978) 125

97 (1979) 241

92 (1978) 5

91 (1978) 310

95 (1978) 49

93 (1978) 51

93 (1978) 51

96 (1978) 155

99 (1979) 210

92 (1978) 195

98 (1978) 9

94 (1978) 166

95 (1978) 31

91 (1978) 202

95 (1978) 181

91 (1978) 329

96 (1978) 135

97 (1979) 65

97 (1979) 555

100 (1979) 276

97 (1979) 279

96 (1978) 26 
Battaini, F., see K. Kumakura

93 (1978) 231

Battersby, A.R., J. Staunton, J. Klinman and M.C. Summers, Stereochemistry of oxidation of benzylamine by the amine oxidase from beef plasma

Battistini, A., see M. Tomasi

Bâuerlein, E., see $H$. Trasch

Baumbach, G., see M.N. Horst

Bavoil, P., see H. Sandermann, jr

Baxter, J.D., see S.-y. Cheng

Baxter, M.A., M.A. Goheer and H.G. Coore, Absent pyruvate inhibition of pyruvate dehydrogenase kinase in lactating rat mammary gland following various treatments-removal of circulating insulin and prolactin and prolactin and exposure to protein synthesis inhibitors

Baxter, M.A. and H.G. Coore, Starvation of lactating rats leads to alterations in the behaviour of pyruvate dehydrogenase kinase which persist in the semi-purified pyruvate dehydrogenase complex of the mammary gland but are partly reversible in vitro

Bayer, M.E., see M. Wong

Bazely, N., see J. Redel

Bazin, H., see J. Rousseaux

Bear, D.G., T. Schleich, H.F. Noller, S. Douthwaite and R.A. Garrett, The ribosomal S4-RNA fragment melts cooperatively when complexed with protein $\mathrm{S} 4$

Béchet, J.-M., see M.-E. Mouttet

Beck, G., J.-P. Beck, C. Bollack and A. Belarbi, Regulation of tyrosine aminotransferase synthesis in vitro by mRNA and soluble factors from hepatoma tissue culture cells

Beck, G., see B. Rether

Beck, J.-P., see G. Beck

Becker, E.L., see R.I. Sha'afi

Becker, E.L., see R.J. Petroski

Beckhaus, G., see J. Puente

Beckner, S. and M. Blecher, Kinetics of activation of ADP-ribosylation and adenylate cyclase by cholera toxin in cloned differentiated hepatocytes

Beconi, M.T., see Boveris

Beeler, T. and A. Martonosi, The relationship between membrane potential $\mathrm{Ca}^{2+}$ fluxes in isolated sarcoplasmic reticulum vesicles

Befort, J.-J, see A.-M. Leseney

Befort, N., see A.-M. Leseney

Behrens, N.H., see N.I. de Iannino

Beitner, R. and J. Nordenberg, The regulatory role of glucose 1,6-diphosphate in muscle of dystrophic mice

Beisiegel, U., see G. Utermann

Belarbi, A., see G. Beck

Belarbi, A., see B. Rether

Belew, M., J. Fohlman and J.C. Janson. Gel filtration of proteins on Sephacryl ${ }^{\circledR}$ S-200 superfine in $6 \mathrm{M}$ guanidine-HC1

Belkin, S. and E. Padan, Sulfide-dependent hydrogen evolution in the cyanobacterium Oscillatoria limnetica

Beltran, J.P. and G.A. Strobel, Rhynchosporoside binding proteins of barley

Bemski, G., see E. Wajnberg

Benecky, M., see J. Schmidt

Benemann, J.R., see P.C. Hallenbeck

Benezra, R., see $M$. Recasens

Ben-Hayyim, G., see N. Porat

Benmiloud, M., see A.-M. Leseney

Bennet, N. and Y. Dupont, Use of Ca EGTA buffers for transposing $\mathrm{Ca}^{2+}$ efflux into pH changes. Application to rod outer segment membrane vesicles

Bentor-Getter, V., see L. Reshef

Benzie, C.R., see J.E. Kay

Bercovici, J., see K. Schwartz

Berge, R., see A.M. Bakken

Bergelson, L.D., see R.M. Hoffman

99 (1979) 297

94 (1978) 253

97 (1979) 133

100 (1979) 385

95 (1978) 107

100 (1979) 113

$97(1979) \quad 27$

98 (1979) 195

95 (1978) 26

94 (1978) 228

98 (1979) 359

$100(1979) \quad 99$

100 (1979) 107

93 (1978) 189

93 (1978) 194

$93(1978) 189$

91 (1978) 305

100 (1979) 161

99 (1979) 215

95 (1978) 319

92 (1978) 333

98 (1979) 173

99 (1979) 239

99 (1979) 239

99 (1979) 73

98 (1979) 199

97 (1979) 245

93 (1978) 189

93 (1978) 194

91 (1978) 302

94 (1978) 291

96 (1978) 34

91 (1978) 257

96 (1978) 263

94 (1978) 261

99 (1979) 51

92 (1978) 9

99 (1979) 239

98 (1979) 229

97 (1979) 96

91 (1978) 40

93 (1978) 137

99 (1979) 47

93 (1978) 365 
Berger, E.G. and I. Kozdrowski, Permanent mixed-field polyagglutinable erythrocytes lack galactosyltransferase activity

Berlet, H.H. and T. Lehnert, Differential isoenzyme pattern of soluble and particle-bound lactate dehydrogenase of rat brain

Bernabeu, C., D. Vazquez and J.P.G. Ballesta, Conformational changes in ribosomes induced by alcohols

Bernard, H.F., see E.P. Krenning

Bernard, P. and G. Rocquet, Effect of whole-body irradiation on Michaelis-Menten constants of microsomal enzyme systems of rat liver

Berrissi, H., see A. Schmidt

Bertini, I., C. Luchinat and A. Scozzafava, A ${ }^{31 P}$ NMR study of phosphate in presence of cobalt (II)- and copper (II)-substituted bovine carbonic anhydrase B

Betz, H., Loss of sporulation ability in yeast mutant with low proteinase A levels

Beyerman, H.C., see K.H. Dahl

Beyerman, H.C., see K.H. Dahl

Beynen, A.C., see M.J.H. Geelen

Beynon, P.J., see P.J. Sadler

Beyreuther, K., see F. Buck

Bezard, J., see P. Clouet

Bhakdi, S., B. Bhakdi-Lehnen, O.J. Bjerrum and J. Tranum-Jensen, Difference in antigenic reactivity and ultrastructure between fluid-phase $\mathrm{C} 5 \mathrm{~b}-9$ and the $\mathrm{C} 5 \mathrm{~b}-9$ membrane attack complex of human complement

Bhakdi-Lehnen, B., see S. Bhakdi

Bhatnagar, R.S., R.S. Rapaka and D.W. Urry, Interaction of polypeptide models of elastin with propyl hydroxylase

Bhattacharyya, B., see A.C. Banerjee

Bhuta, A. and S. Chládek, Stereochemical control of the ribosomal peptidyltransferase reaction: the role of acceptor substrate amino acid side chain orientation

Bick, M.D., see J. Kallos

Bieganowski, R. and W. Friedrich, Preparation and some properties of ferribalamin, the Fe(III)-analogue of vitamin $\mathbf{B}_{12}$

Bieglmayer, Ch., see J. Spona

Bielka, H., see P. Westermann

Bieri-Bonniot, F. and A.R. Schuerch, Molecular heterogeneity of DNA polymerase $\alpha$ from P815 mouse mastocytoma cells

Bignetti, E., G.L. Rossi and E. Zeppezauer, Micro-spectrophotometric measurements on single crystals of coenzyme containing complexes of horse liver alcohol dehydrogenase

Bilton, R.F., see M.E. Tenneson

Birnbaum, E.R., see L. Lee

Biryukov, A.I., T.I. Osipova and R.M. Khomutov, $\alpha$-Aminophosphonous acids: the substrates of ATP-PP exchange reaction, catalysed by aminoacyl-tRNA synthetases

Biryukov, A.I, B.Kh. Ishmuratov and R.M. Khomutov, Transition-state analogues of aminoacyl adenylates

Biserte, $G$., see B. Laine

Biserte, G., see J. Rousseaux

Bisse, E. and D.J. Vonderschmitt, Immobilization of glucose dehydrogenase by titanium tetrachloride

Bisson, R., H. Gutweniger and A. Azzi, Photoaffinity labeling of yeast cytochrome oxidase with arylazido cytochrome $c$ derivatives

Biszku, E., see E. Cseke

Bitny-Szlachto, S., see D. Soltysiak-Pawluczuk

Bjerrum, O.J., see S. Bhakdi

Björk, I., see W.W. Fish

Björkhem, I., see J.I. Pedersen

Black, C.C., see W.H. Kenyon

Blackmore, P.F., J.-P. Dehaye, W.G. Strickland and J.H. Exton, $\alpha$-Adrenergic mobilization of hepatic mitochondrial calcium

Blăha, K., see J. Vičar

Blaschkowski, H.P., J. Knappe and Th. Wieland, S-Ethyl-coenzyme A and acetonyldethio-coenzyme A: Interactions with pyruvate carboxylase and phosphotransacetylase

Blecher, M., see S. Beckner

$93(1978) 105$

91 (1978) 45

99 (1979) 251

$91(1978) 113$

98 (1979) 260

95 (1978) 257

93 (1978) 251

100 (1979) 171

99 (1979) 308

99 (1979) 313

95 (1978) 326

94 (1978) 315

96 (1978) 335

93 (1978) 165

99 (1979) 15

99 (1979) 15

95 (1978) 61

99 (1979) 333

96 (1978) 23

98 (1979) 347

97 (1979) 325

97 (1979) 269

97 (1979) 101

$96(1978) 192$

$100(1979) \quad 17$

91 (1978) 140

98 (1979) 169

91 (1978) 246

91 (1978) 249

96 (1978) 291

98 (1979) 359

93 (1978) 102

92 (1978) 219

96 (1978) 15

96 (1978) 173

99 (1979) 15

98 (1979) 103

98 (1979) 394

94 (1978) 281

100 (1979) 117

97 (1978) 275

98 (1979) 81

95 (1978) 319 
Blitz, A.L., see R.E. Fine

Bloemendal, H., see F.A.M. Asselbergs

Bloj, B., M.E., Hughes, D.B. Wilson and D.B. Zilversmit, Isolation and amino acid analysis of a nonspecific phospholipid transfer protein from rat liver

Bloom, M., see I.C.P. Smith

Blow, A.M.J., G.M. Botham, D. Fisher, A.H. Goodall, C.P.S. Tilcock and J.A. Lucy, Water and calcium ions in fusion induced by poly(ethylene glycol)

Blow, A.M.J. see Q.F. Ahkong

Bocchini, V., see G. Sander

Bocian, D.F., see T.H. Stevens

Bock, E., see M. Treiman

Boggs, R.T., see J.P. Markwell

Bøg-Hansen, H.C., H.H. Krog and U. Back, Plasma lipoprotein-associated arylesterase is induced by bacterial lipopolysaccharide

Bogucka, K. and L. Wojtczak, On the mechanism of mercurial-induced permeability of the mitochondrial membrane to potassium ions

Boguslaski, R.C., see F. Kohen

Boiden Pedersen, J., Determination of the primary reactions to photosynthesis from transient ESR signals

Boitieux, J.-L., G. Desmet and D. Thomas, Immobilization of anti $\mathrm{Hb}_{\mathrm{s}} \mathrm{A} 9$ antibodies on artificial proteic membranes

Bollack, C., see G. Beck

Bolshakova, T.N., see A.M. Umyarov

Bommer, U.-A., see P. Westermann

Bon, S., see S. Carson

Bonnafous, J.-C., J. Dornand and J.-C. Mani, Deactivation of lymphocyte adenylate cyclase by affinity chromatography on Con A Sepharose. Its reactivation by a cytosolic factor

Bonner, W.D., jr, see P.R., Rich

Bonnet, F., see J.-P. Périn

Boos, K.-S., R. Bridenbaugh, R. Ronald and R.G. Yount, Microsynthesis of photolabile 8- $\left[2-{ }^{3} \mathrm{H}\right]-$ azidoadenosine nucleotides

Borisov, V.V., see A.G. Pavlovsky

Borisova, S.N., see A.G. Pavlovsky

Bornens, M., see B. Maro

Borová, J., see P. Poǹka

Bosisio, A.B., see R. Krishnamoorthy

Bossa, F., see F. Marmocchi

Bosshard, H.R., see R. Rieder

Bösterling, B., see A. Stier

Bot, G., see P. Gergely

Botha, M.C., R. Stathopoulou, H. Lehmann, J.S. Rees and D. Plowman, A Hb J Cape Town homozygote association of $\mathrm{Hb} \mathrm{J}$ Cape Town and alpha-thalassaemia

Botham, G.M., see A.M.J. Blow

Botham, G.M., see Q.F. Ahkong

Böttger, I., see G. Dietze

Böttger, I., see M. Wicklmayr

Bouchilloux, S., see C. Ronin

Bouges-Bocquet, B., Reactions leading to the photo-induced reduction of ferredoxin-NADP-reductase (FNR) in chlorella cells

Bouges-Bocquet, B. and R. Delosme, Evidence for a new electron donor to P-700 in Chlorella pyrenoidosa

Boulay, F., G. Brandolin, G.J.M. Lauquin, J. Jollès, P. Jolles and P.V. Vignais, An ADP- and atractyloside-

binding protein involved in ADP/ATP transport in yeast mitochondria. Isolation and amino acid composition

Bouveret, P., see K. Schwartz

Boveris, A., R.A. Sánchez and M.T. Beconi, Antimycin- and cyanide-resistant respiration and superoxide anion production in fresh and aged potato tuber mitochondria

Bowles, D.J., see C.M.T. Kieda

Bowman, M.K., see M.C. Thurnauer
94 (1978) 59

94 (1978) 195

96 (1978) 87

$100(1979) 57$

94 (1978) 305

95 (1978) 147

98 (1979) 111

97 (1979) 314

97 (1979) 147

99 (1979) 4

93 (1978) 86

100 (1979) 301

100 (1979) 137

97 (1979) 305

93 (1978) 133

93 (1978) 189

96 (1978) 31

97 (1979) 101

97 (1979) 348

99 (1979) 152

93 (1978) 323

94 (1978) 257

91 (1978) 285

92 (1978) 258

92 (1978) 258

97 (1979) 116

97 (1979) 317

94 (1978) 319

94 (1978) 109

92 (1978) 223

91 (1978) 109

93 (1978) 239

96 (1978) 331

94 (1978) 305

95 (1978) 147

92 (1978) 294

98 (1979) 61

96 (1978) 179

94 (1978) 95

95 (1978) 100

98 (1979) 161

93 (1978) 137

92 (1978) 333

94 (1978) 391

100 (1979) 309 
Bownes, M. and B.D. Hames, Analysis of the yolk proteins in Drosophila melanogaster: translation in a cell free system and peptide analysis

Bownes, M., Three genes for three yolk proteins in Drosophila melanogaster

Boxer, D.H., see G. Giordano

Boyer, J., see J. Amaud

Boyer, P.D., see C. Vinkler

Bozsik, M., see S. Soboll

Bradbury, E.M., see K. Mitchelson

Bradley, W.A. and G.A. Somkuti, The primary structure of sillucin, an antimicrobial peptide from Mucor pusillus

Brady, R.O., see C.J. Steer

Bragg, P.D., see A.P. Singh

Brand, M.D., W.G. Harper, D.G. Nicholls and W.J. Ingledew, Unequal charge separation by different coupling spans of the mitochondrial electron transport chain

Brandolin, G., see F. Boulay

Brandt, W.F., see C. von Holt

Brandts, J.F., see K.S. Krishnan

Brauer, D., see J.Y. Chang

Brauer, D. and I. Öchsner, The primary structure of protein L1 from the large ribosomal subunit of Escherichia coli

Braun, D.G., see J.K. Wright

Braun, R., see U. Gubler

Brazhnikov, E.V., A.B. Chetverin and Yu.N. Chirgadze, Secondary structure of $\mathrm{Na}^{+}, \mathrm{K}^{+}$-dependent adenosine triphosphatase

Bridenbaugh, R., see K.-S. Boos

Bridges, J.W., see M.J. O'Sullivan

Brinley, F.J., jr, T. Tiffert and A. Scarpa, Kinetics of calcium accumulation by mitochondria, studied in situ, in squid giant axons

Brown, J.S., see G. van Ginkel

Brown, N.L., A primed-synthesis method for ribosubstitution of DNA at a single site

Browne, M.J., A.C.B. Cato and R.H. Burdon, The distribution of modified and non-modified CG doublets in BHK-21 cell DNA

Browning, J.L, see J. Seelig

Brozmanová, J., see M. Sedliaková

Bruckdorfer, K.R., see C. Rice-Evans

Brunner, J., see G. Frank

Brunori, M., see H.A. Kuiper

Bryce, C.F.A., C.G.M. Magnusson and R.R. Crichton, A reappraisal of the electrophoretic patterns obtained from ferritin and apoferritin in the presence of denaturants

Brzin, J., see Kopitar, M.,

Buc, H., see M. Dreyfus

Buchardt, O., see P.E. Nielsen

Buck, F., see H. Rüterians and K. Beyreuther, ${ }^{1}$ H NMR study of the lactose repressor from Escherichia coli

Budker, V.G., Yu.A. Kazatchkov and L.P. Naumova, Polynucleotides adsorb on mitochondrial and model lipid membranes in the presence of bivalent cations

Buettner, G.R., see L.W. Oberley

Buettner, G.R. and L.W. Oberley, Superoxide formation by protoporphyrin as seen by spin trapping

Buniatian, H.Ch., see V.S. Gasparov

Burchell, A., J.G. Foulkes, P.T.W. Cohen, G.D. Condon and P. Cohen, Evidence for the involvement of protein phosphatase- 1 in the regulation of metabolic processes other than glycogen metabolism

Burchell, A., see P. Cohen

Burckhardt, G., see C.-U. von Mickwitz

Burd, J.F., see F, Kohen

Burditt, L.I., K.A. Chotai and B.G. Winchester, Evidence that the mutant enzyme in fibroblasts of a patient with mannosidosis does not crossreact with antiserum raised against normal acidic $\alpha$-D-mannosidase

Burdon, R.H., see M.J. Browne

Burdon, R.H., see A.C.B. Cato

96 (1978) 327

$100(1979) \quad 95$

95 (1978) 290

99 (1979) 43

$96(1978) 129$

$100(1979) 125$

92 (1978) 339

97 (1979) 81

91 (1978) 202

98 (1979) 21

95 (1978) 125

98 (1979) 161

100 (1979) 201

91 (1978) 206

93 (1978) 205

96 (1978) 317

93 (1978) 317

100 (1979) 347

93 (1978) 125

91 (1978) 285

95 (1978) 311

91 (1978) 25

94 (1978) 284

$93(1978) \quad 10$

91 (1978) 69

92 (1978) 41

92 (1978) 133

94 (1978) 81

96 (1978) 183

$99(1979) 317$

96 (1978) 257

91 (1978) 355

95 (1978) 185

94 (1978) 287

96 (1978) 335

95 (1978) 143

97 (1979) 47

98 (1978) 18

97 (1979) 37

92 (1978) 68

92 (1978) 287

98 (1979) 324

$100(1979) \quad 137$

91 (1978) 186

91 (1978) 69

99 (1979) 33 


\section{FEBS LETTERS}

Burgen, A.S.V., see J. Degelaen

98 (1979) 53

Burgoyne, R.D., A model for the molecular basis of circadian rhythms involving monovalent ion-mediated translational control

Burke, G., see S. Huprikar

Burley, R.W., see A.S. Inglis

Burtnick, L.D. and P.L. Schaar, Circular polarization of the fluorescence of actin-bound $\varepsilon$ ATP: Effects of binding DNase I

Busch, H., see M. Fuke

Butler, K.W., see I.C.P. Smith

Butler, W.L., On the role of cytochrome $b_{559}$ in oxygen evolution in photosynthesis

Butters, T.D., see G.J. Dimitriadis

Büttner, W., see J. Adamkiewicz

Bygrave, F.L., see R.L. Smith

94 (1978) 17

99 (1979) 167

97 (1979) 179

97 (1979) 166

99 (1979) 136

100 (1979) 57

95 (1978) 19

98 (1979) 33

94 (1978) 199

95 (1978) 333

Cahen, D., H. Garty and S.R. Caplan, Spectroscopy and energetics of the purple membrane of Halobacterium halobium: A photoacoustic study

Cahen, D., S. Malkin and E.I. Lerner, Photoacoustic spectroscopy of chloroplast membranes; listening to photosynthesis

Cairns, E., W. Doerfler and H.-G. Schweiger, Expression of a DNA animal virus genome in a plant cell

Calando, Y., see J. Redel

Camier, M., see M. Lauber

Cammack, R., J.J. Maguire and L. Packer, Interaction of ionic detergents with iron sulfur centers in beef heart mitochondrial membranes

Campbell, P.N. and R.K. Craig, Hormonal regulation of specific gene expression

Cancedda, F., see C.Y. Lai

Cancedda, R., see A. Leone

Candido, E.P.M., see R. Reeves

Canioni, P. and P.J. Cozzone, Proton NMR study at $360 \mathrm{MHz}$ of porcine pancreatic colipase. Identification of aromatic resonances

Caplan, S.R., see D. Cahen

Cappuccinelli, P., G. Martinotti and B.D. Hames, Identification of cytoplasmic tubulin in Dictyostelium discoideum

Capri, M., C. Molinier-Jumel, V. Barthelemy-Clavey and G. Aubel-Sadron, Inhibition of mammalian RNA polymerases by a protein factor from Ehrlich ascites tumor cells

Carafoli, E., see I. Roos

Carafoli, E., see P. Caroni

Carafoli, E., see H.R. Lötscher

Carbon, P., C. Ehresmann, B. Ehresmann and J.P. Ebel, The sequence of Escherichia coli ribosomal 16 S RNA determined by new rapid gel methods

Carlberg I. and B. Mannervik, Inhibition of glutathione reductase by interaction of 2,4,6-trinitrobenzenesulfonate with the active-site dithiol

Caroni, P., K. Schwerzmann and E. Carafoli, Separate pathways for $\mathrm{Ca}^{2+}$ uptake and release in liver mitochondria

Carr, J., see J.D. Clemmer

Carr, J.W., see D.B. Knaff

Carre, M., see J. Redel

Carson, S., S. Bon, M. Vigny, J. Massoulié and M. Fardeau, Distribution of acetylcholinesterase molecular forms in neural and non-neural sections of human muscle

Carteni-Farina, M., see V. Zappia

Casey, R.P., see J.J. Schuurmans

Cass, A.E.G., A. Galdes, H.A.O. Hill, C.E. McClelland and C.B. Storm, Heavy metal binding to biological molecules: identification of ligands by observation of ${ }^{199} \mathrm{Hg}-{ }^{1} \mathrm{H}$ coupling

Castagna, M., C. Rochette-Egly, C. Rosenfeld and Z. Mishal, Altered lipid microviscosity in lymphoblastoid cells treated with 12-0-tetradecanoyl phorbol 13-acetate, a tumor promoter

Castillo, O., H. Lehmann and R. Diamond, Selection at molecular level in mammalian myoglobins

Caterson, 1.D. and K.W. Taylor, Direct effects of gold thioglucose on insulin secretion by isolated rat islets of Langerhans

Cato, A.C.B., see M.J. Browne

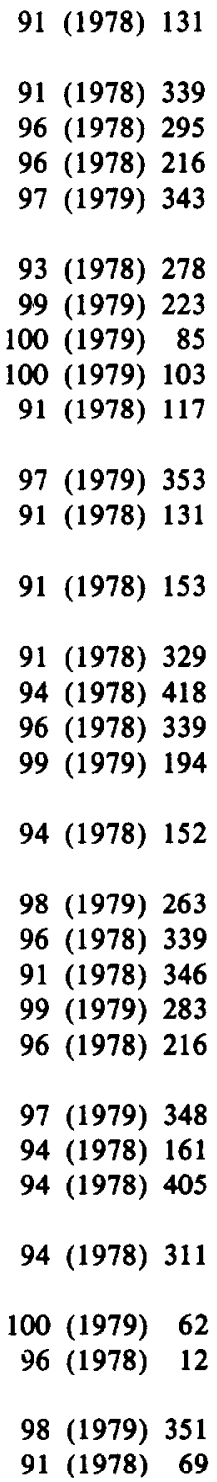


Cato, A.C.B. and R.H. Burdon, Mammalian DNA methylation and a nuclear $S$-adenosyl L-methioninedependent nucelase activity

$99(1979) \quad 33$

92 (1978) 346

Cave, A., J. Parello, T. Drakenberg, E. Thulin and B. Lindman, $\mathbf{M g}^{2+}$ binding to parvalbumins studied by ${ }^{23} \mathrm{Mg}$ and ${ }^{13} \mathrm{Cd}$ NMR spectroscopy

Ceccarelli, A., G.P. Dotto, F. Altruda, C. Perlo, L. Silengo, E. Turco and G. Mangiarotti, Immature 50 S subunits in Escherichia coli polyribosomes

Cecchini, J.P., see R. Miassod

Cederblad, G., J. Holm, G. Lindstedt, S. Lindstedt, I. Nordin and T. Scherstén, $\gamma-$ Butyrobetaine hydroxylase activity in human and ovine liver and skeletal muscle tissue

Cenatiempo, Y., see A. Genot

Chak, D. v., see B. Rauch

Chakhmakhcheva, O.G., see Yu.A. Ovchinnikov

Chambaz, E.M., see D. Job

Chambers, T., see K. Mitchelson

Champion, S. and C. Jacquemin, The role of cyclic GMP in the action of carbamylcholine on the cyclic AMP level in the dog thyroid

Chan, S.I., see T.H. Stevens

Chang, C.K., see G.T. Babcock

Chang, D., see C.,Y. Lai

Chang, J.Y., A. novel Edman-type degradation: direct formation of the thiohydantoin ring in alkaline solution by reaction of Edman-type reagents with $N$-monomethyl amino acids

Chang, J.Y., D. Brauer and B. Wittmann-Liebold, Micro-sequence analysis of peptides and proteins using 4-NN-dimethylamino-azobenzene 4 '-isothiocyanate/phenyl isothiocyanate double coupling method

Changeux, J.-P., see T. Heidmann

Chap, H., see G. Mauco

Chapman, D.J., see S.L. Manley

Chapman, D., see W. Hoffmann

Chapman, D., J.C. Gómez-Fernández and F.M. Goñi, Intrinsic protein-lipid interactions: Physical and biochemical evidence

Chapman, D., see J.C. Gómez-Fernández

Charlier, J., see E. Gerlo

Chafrier, B., see A. Margotat

Chauvet, J, see M.T. Chauvet

Chauvet, M.T., P. Codogno, J. Chauvet and R. Acher, Comparison between MSEL- and VLDV-neurophysins: Complete amino acid sequences of porcine and bovine VLDV-neurophysins

Cheah, A.M., see K.S. Cheah

Cheah, K.S. and A.M. Cheah, Calcium movements in skeletal muscle mitochondria of malignant hyperthermic pigs

Cheng, C.H.K. and E.D. Saggerson, Rapid antagonistic actions of noradrenaline and insulin on rat adipocyte phosphatidate phosphohydrolase activity

Cheng, L.Y.L. and L. Packer, Photodamage to hepatocytes by visible light

Cheng, S.-y., N.L. Eberhardt, J. Robbins, J.D. Baxter and I. Pastan, Fluorescent rhodamine-labeled thyroid hormone derivatives: synthesis and binding to the thyroid hormone nuclear receptor

Cheng, T.-c., see J.A. Phillips, iii

Chetverin, A.B., see E.V. Brazhnikov

Chiancone, E., see J.-E. Norne

Chiancone, E., see S. Stefanini

Chibata, I., see T. Shibatani

Chieregatti, G., see M.J. O'Sullivan

Childs, R.A. and T. Feizi, Calf heart lectin reacts with blood group li antigens and other precursor chains of the major blood group antigens

Chilson, O.P., see S. Lemley

Chirgadze, Yu.N., see E.V. Brazhnikov

Chládek, S., see A. Bhuta

Chon, C.J., see H.W. Heldt

Chotai, K.A., see L.J. Burditt
$100(1979) 148$

93 (1978) 348

96 (1978) 273

98 (1979) 57

99 (1979) 261

$93(1978) 65$

100 (1979) 341

98 (1979) 303

92 (1978) 339

92 (1978) 156

97 (1979) 314

97 (1979) 358

$100(1979) \quad 85$

91 (1978) 63

93 (1978) 205

94 (1978) 397

100 (1979) 367

$93(1978) \quad 97$

95 (1978) 31

98 (1979) 211

98 (1979) 224

99 (1979) 25

95 (1978) 347

98 (1979) 37

98 (1979) 37

95 (1978) 307

95 (1978) 307

93 (1978) 120

97 (1979) 124

100 (1979) 113

97 (1979) 327

93 (1978) 125

94 (1978) 410

100 (1979) 296

96 (1978) 389

95 (1978) 311

99 (1979) 175

94 (1978) 51

93 (1978) 125

96 (1978) 23

92 (1978) 234

91 (1978) 186 


\section{FEBS LETTERS}

Christiansen, E.N., see J. Norseth

97 (1979) 163

Christiansen, R.Z., see M.J.H. Geelen

Christophe, J., see M. Svoboda

Christophe, J., see M. Lambert

Christophersen, B.O., see J. Norseth

Chulitskaya, E.V., see S.M. Elizarov

Cittanova, N., see P. Urios

Ciudad, C.J., J. Massagué and J.J. Guinovart, The inactivation of glycogen phosphorylase is not a prerequisite for the activation of liver glycogen synthase

Clarke, D.J., F.M. Fuller and J.H. Morris, The membrane adenosine triphosphatase of Clostridium pasteurianum. Effects of key intermediates of glycolysis on its ATP phosphohydrolase activity

Clarke, R.H., W.R. Leenstra and W.G. Hagar, Observation of a triplet state in chlorophyll protein 668 via optically detected magnetic resonance

Claridge, R.F.C., see C.C. Winterbourne

Claesson, H.-E., see J.Ä Lindgren

Clementi, E., G. Corongiu, B. Jönsson and S. Romano, The water structure in the active cleft of human carbonic anhydrase B. A Monte Carlo simulation

Clemmer, J.D., J. Carr, D.B. Knaff and R.A. Holwerda, Modification of laccase tryptophan residues with 2-hydroxy-5-nitrobenzyl bromide

Clouet, P. and J. Bezard, Chain shortening of erucic acid by subcellular particles isolated from liver and heart of rat

Cochet, C., see D. Job

Cockrell, R.S., see G. Fiskum

Codington, J.F., T. Yamazaki, D.H. van den Eijnden, N.A. Evans and R.W. Jeanloz, Unequivocal evidence for a $\beta$-D-configuration of the galactose residue in the disaccharide chain of epiglycanin, the major glycoprotein of the TA3-Ha tumor cell

Codogno, P., see M.T. Chauvet

Cohen, P., see D.G. Hardie

Cohen, P., see A. Burchell

Cohen, P., A. Burchell, J.G. Foulkes, P.T.W. Cohen, T.C. Vanaman and A.C. Nairn, Identification of the $\mathrm{Ca}^{2+}$-dependent modulator protein as the fourth subunit of rabbit sketetal muscle phosphorylase kinase

Cohen, P., see M. Lauber

Cohen, P., see D.B. Rylatt

Cohen, P., see D.B. Rylatt

Cohen, P.T.W., see A. Burchell

Cohen, P.T.W., see P. Cohen

Colli, W., see M.J.M. Alves

Colomb, M.G., see R.B. Sim

Colonna, R., see G.F. Azzone

Condon, G.D., see A. Burchell

Conlon, J.M., E. Zyznar, W. Vale and R.H. Unger, Multiple forms of somatostatin-like immunoreactivity in canine pancreas

Cooney, G.J., see A.G. Dawson

Cooper, A., Energetics of rhodopsin and isorhodopsin

Cooper, M.B., see J.A. Craft

Coore, H.G., see M.A. Baxter

Coore, H.G., see M.A. Baxter

Coote, J.L., Gy. Szabados and T.S. Work, The heterogeneity of mitochondrial DNA in different tissues from the same animal

Corongiu, G., see E. Clementi

Costa, J.L., C.M. Dobson, K.L. Kirk, F.M. Poulsen, C.R. Valeri and J.J. Vecchione, Studies of human platelets by ${ }^{19} \mathrm{~F}$ and ${ }^{31} \mathrm{P}$ NMR

Costa, M.T., S. Sabatini, P. Turini and B. Mondovi, Inhibition of beef plasma amine oxidase activity by glycine

Côté, G.P., W.G. Lewis and L.B. Smillie, Non-polymerizability of platelet tropomyosin and its $\mathrm{NH}_{2}-$ and COOH-terminal sequences

Côté, G.P., W.G. Lewis, M.D. Pato and L.B. Smillie, Platelet tropomyosin: lack of binding to skeletal muscle troponin and correlation with sequence

95 (1978) 326

92 (1978) 351

99 (1979) 303

97 (1979) 163

93 (1978) 219

94 (1978) 54

99 (1979) 321

$100(1979) \quad 52$

99 (1979) 207

94 (1978) 269

98 (1979) 247

100 (1979) 313

91 (1978) 346

93 (1978) 165

98 (1979) 303

92 (1978) 125

99 (1979) 70

98 (1979) 37

91 (1978) 1

92 (1978) 68

92 (1978) 287

97 (1979) 343

98 (1979) 71

98 (1979) 76

92 (1978) 68

92 (1978) 287

99 (1979) 81

97 (1979) 111

96 (1978) 141

92 (1978) 68

94 (1978) 327

91 (1978) 169

100 (1979) 382

98 (1979) 403

97 (1979) 27

98 (1979) 195

99 (1979) 255

100 (1979) 313

99 (1979) 141

94 (1978) 112

91 (1978) 237

94 (1978) 131 
Cottalasso, D., see G. Nanni

Counis, R., S. Mongongu, M. Pierre, J.E. Loeb and M. Jutisz, Norepinephrine control of endogenous polypeptide phosphorylation in white fat cells

$96(1978) \quad 69$

Cowburn, D., see A.J. Fischman

Cox, J.C., R. Aasa and B.G. Malmström, EPR studies on the blue copper protein, rusticyanin: a protein involved in $\mathrm{Fe}^{2+}$ oxidation at $\mathrm{pH} 2.0$ in Thiobacillus ferro-oxidans

Cox, J.C., W.J. Ingledew, B.A. Haddock and H.G. Lawford, The variable cytochrome content of Paracoccus denitrificans grown aerobically under different conditions

Cozzone, A.J., see A. Genot

Cozzone, P.J., see P. Canioni

Crabbe, M.J.C. and J.J. Harding, Collagen crosslinking: Isolation of two crosslinked peptides involving $\alpha 2-\mathrm{CB}(3-5)$ from bovine scleral collagen

Crabbe, M.J.C., see J.J. Harding

Craft, J.A., M.B. Cooper, M.R. Estall and B.R. Rabin, The biosynthesis of cytochrome P450 by rough endoplasmic reticulum in vitro. A significant proportion of newly biosynthesised cytochrome $\mathrm{P} 450$ is resistant to proteolytic digestion in intact vesicles

Craig, R.K., see P.N. Campbell

Crane, F.L., see H. Löw

Crechet, J.-B., see G. Sander

Crifo, C., see R. Strom

Crighton, D.B., see A.D. Swift

Crichton, R.R., see C.F.A. Bryce

Crichton, R.R., see M. Wauters

Crompton, M., see I. Roos

Crowther, D., J.D. Mills and G. Hind, Protonmotive cyclic electron flow around photosystem I in intact chloroplasts

Cseke, E., A. Varadi, G. Szabolcsi and E. Biszku, On the molecular sieving property of the human erythrocyte membrane and the localization of some glycolytic enzymes in the cell

Cser, L., F. Franèk, I.A. Gladkikh, R.S. Nezlin, J. Novotný and Yu.M. Ostanevich, Distance between two binding sites of the same antibody molecule: A neutron small-angle scattering study of pig anti-Dnp antibody complexed with mono-Dnp-dextran

Cummings, M.R., see R.E. Law

Curthoys, N.P., see R.A. Shapiro

D'Agnolo, G., see M. Tomasi

Dahl, K.H., J.S. McKinley-McKee, H.C. Beyerman and A. Noordam, Metal-directed affinity labelling. Inactivation and inhibition studies of two zinc alcohol dehydrogenases with twelve imidazole derivatives

Dahl, K.H., J.S. McKinley-McKee, H.C. Beyerman and A. Noordam, Stereoselective metal-directed affinity labelling. A model inactivation study with alcohol dehydrogenase from liver

Dallas, J.L., see T.T. Sakai

Damaschun, G., see P. Plietz

Damaschun, G., see P. Plietz

Damaschun, H., see P. Plietz

Dancsházy, Zs., L.A. Drachev, P. Ormos, K. Nagy and V.P. Skulachev, Kinetics of the blue light-induced inhibition of photoelectric activity of bacteriorhodopsin

Dankert, M.A., see N.I. de Iannino

Da Silveira, J.F., see M.J.M. Alves

Daune, M.P., see M. Leng

Dautrevaux, M., see F. le Gaillard

Davies, J.E., see M.W. Hsiang

Davis, J.H., see I.C.P.Smith

Davril, M., K.-K. Han, M. Guay and F. Lamy, Photolysis of crosslinked peptides from elastin of porcine aorta

Dawson, A.G. and G.J. Cooney, Reconstruction of the $\alpha$-glycerolphosphate shuttle using rat kidney

mitochondria

Dawson, A.P., see M.J. Selwyn

Dawson, J.R., see M.-L. Aitio

Dean, P.D.G., sec S. Angal

94 (1978) 236

93 (1978) 157

93 (1978) 261

99 (1979) 261

97 (1979) 353

97 (1979) 189

100 (1979) 351

98 (1979) 403

99 (1979) 223

$91(1978) 166$

98 (1979) 111

$96(1978) 45$

100 (1979) 110

96 (1978) 257

91 (1978) 276

94 (1978) 418

98 (1979) 386

$96(1978) \quad 15$

93 (1978) 312

99 (1979) 247

91 (1978) 49

94 (1978) 253

99 (1979) 308

99 (1979) 303

93 (1978) 43

91 (1978) 227

91 (1978) 230

91 (1978) 227

$96(1978) \quad 59$

$99(1979) \quad 73$

99 (1979) 81

92 (1978) 207

94 (1978) 63

$92(1978) \quad 97$

$100(1979) \quad 57$

98 (1979) 128

91 (1978) 169

96 (1978) 148

93 (1978) 29

96 (1978) 346 


\section{FEBS LETTERS}

De Chadarevjan, S., A. de Santis, B.A. Melandri and A. Baccarini Melandri, Oxidative phosphorylation and proton translocation in a lipoate-deficient mutant of Escherichia coli

Deckelbaum, R.J., see M. Fainaru

Decker, K., see R. Stermann

Dedieu, A.G.R., see A.J. Slotboom

Defer, N., see A.-M. Leseney

Defreyn, G., see J. Goris

Degelaen, J., J. Feeney, G.C.K. Roberts, A.S.V. Burgen, J.-M. Frère and J.M. Ghuysen, NMR evidence for the structure of the complex between penicillin and the DD-carboxypeptidase of Streptomyces R61

De Groot, N., see A. Gal

De Haas, G.H., see A.J. Slotboom

Dehaye, J.-P., see P.F. Blackmore

De Herdt, E., see J. Simons

De Iannino, N.I., R.J. Staneloni, N.H. Behrens and M.A. Dankert, Galactose transfer from dolichyl monophosphate galactose in animal tissues

Delaunoy, J.P., see M. Recasens

Delcambe, L., see C. Garbay-Jaureguiberry

De Ley, J., see J. van Beeumen

Delmotte, F., see C. Kieda

Delosme, R., see B. Bouges-Bocquet

DeLuca, H.F., see J. Redel

De Melián, E.M., E.M. Massa, R.D. Morero and R.N. Farias, Membrane cooperative enzymes: interplay of insulin, glucagon and epinephrine on rat erythrocyte acetylcholinesterase system

Demeter, S., T. Herczeg, M. Droppa and G. Horvath, Thermoluminescence characteristics of granal and agranal chloroplasts of maize

De Nayer, Ph., see B. Dozin-van Roye

Dencher, N.A. and M.P. Heyn, Formation and properties of bacteriorhodopsin monomers in the non-ionic detergents octyl- $\beta$-D-glucoside and Triton $\mathrm{X}-100$

Dencher, N.A., see W. Sperling

De Paiva, C.H.R., see M.J.M. Alves

De Rosa, M., see V. Zappia

De Sagarra, M.R., Lack of dietary dependence of liver adenylate kinase levels

De Santis, A., see B.A. Melandri

De Santis, A., see S. de Chadarevjan

Desideri, A., L. Morpurgo, G. Rotilio and B. Mondovi, Stereochemistry of anion complexes of type $2 \mathrm{Cu}$ (II) in Rhus vernicifera laccase. Analogy with superoxide dismutase and $\mathrm{Cu}(\mathrm{II})$ carbonic anhydrase

Desideri, A., see L. Avigliano

Deslauriers, R., see R. Walters

Desmet, G., see J.-L. Boitieux

Devaux, P.F., see A. Rousselet

De Waard, A., J. Korsuize, C.P. van Beveren and J. Maat, A new sequence-specific endonuclease from Anabaena cylindrica

De Wachter, R., see M. Andries

De Wit, J.L. and T.J. Schaafsma, $A^{13} \mathrm{C}$ and ${ }^{1} \mathrm{H}$ NMR study on rod-like polymerization of tobacco mosaic virus protein

d'Herbigny, E., see J.-D. Monet

Diamond, R., see O. Castillo

Dicker, P., see J.E. Kay

Dierks-Ventling, C., Vitellogenin synthesis in isolated hepatocytes

Dietze, G., see M. Wicklmayr

Dietze, G., M. Wicklmayr, I. Böttger and L. Mayer, Insulin action on glucose uptake into skeletal muscle: Inhibition of endogenous biosynthesis of prostaglandins

Dijk, J., see N.N. Khechinashvili

Di Marco, P.N. and I.T. Oliver, Adenosine 3',5'-cyclic monophosphate and enzyme induction in the perinatal rat

Dimitriades, G.J. and T.D. Butters, Liposome-mediated ricin toxicity in ricin-resistant cells

Dixon, R.A., see C.J. Lamb

97 (1979) 293

97 (1979) 171

95 (1978) 214

92 (1978) 361

99 (1979) 239

99 (1979) 279

98 (1979) 53

94 (1978) 25

92 (1978) 361

100 (1979) 117

91 (1978) 53

99 (1979) 73

99 (1979) 51

93 (1978) 151

93 (1978) 373

99 (1979) 329

95 (1978) 100

94 (1978) 228

92 (1978) 143

100 (1979) 321

96 (1978) 152

96 (1978) 322

97 (1979) 129

99 (1979) 81

94 (1978) 161

93 (1978) 228

95 (1978) 130

97 (1979) 293

98 (1979) 339

100 (1979) 318

95 (1978) 357

93 (1978) 133

93 (1978) 161

96 (1978) 106

97 (1979) 69

92 (1978) 273

96 (1978) 79

96 (1978) 12

91 (1978) 40

92 (1978) 109

98 (1979) 61

92 (1978) 294

95 (1978) 270

94 (1978) 183

98 (1979) 33

94 (1978) 277 
Dobbie, G.J, see G. Kranias

92 (1978) 357

Dobson, C.M., see J.L. Costa

99 (1979) 141

Docter, R, see E.P. Krenning

$91(1978) 113$

Doerfler, W., see E. Cairns

$96(1978) 295$

Dolan, E., see V.A. Shuvalov

100 (1979) 5

100 (1979) 133

Dolhofer, R. and O.H. Wieland, Preparation and biological properties of glycosylated insulin

Dombrádi, V., see P. Gergely

Domdey, H., see H.L. Sänger

Domogatsky, S.P., T.N. Vlasik, T.A. Seryakova, L.P. Ovchinnikov and A.S. Spirin, Difference in

RNA-binding ability between eukaryotic and prokaryotic elongation factors of translation

Dondon, J., see M. Laughrea

Donella Deana, A., see F. Meggio

Dootson, G., see C. Rice-Evans

Dorland, L., see D. Leger

Dornand, J., see J.-C. Bonnafous

Dottavio-Martin, D., D.P. Suttle and J.M. Ravel, The effects of initiation factors IF-1 and IF-3 on the dissociation of Escherichia coli $70 \mathrm{~S}$ ribosomes

Dotto, G.P., see A. Ceccarelli

Douste-Blazy, L., see G. Mauco

Douthwaite, S., see D.G. Bear

Dozin-van Roye, B. and $\mathrm{Ph}$. de Nayer, Triiodothyronine binding to brain cytosol receptors during maturation

Drachev, L.A., see Zs. Dancsházy

Drakenberg, T., A. Cave, J. Parello and B. Lindman, Non-equivalence of the CD and EF sites of muscular parvalbumins. A ${ }^{113} \mathrm{Cd}$ NMR study

Drakenberg, T., see A. Cave

Dreyfus, M., B. Vandenbunder and H. Buc, Stabilization of a phosphorylase $b$ active conformation by hydrophobic solvents

Driver, H.A., see J.W.N. Akkerman

Drobinskaya, I.E, I.A. Kozlov and V.P. Skulachev, ATP-induced inhibition in mitochondrial ATPase by oligomycin

Drobinskaya, I.E., see E.A. Imedidze

Droppa, M., see S. Demeter

Dryburgh, H., see K. Edwards

Duance, V.C., see A.J. Bailey

Dudkin, S.M., see G.A. Aphanasenko

Dudley, P.A. and R.E. Anderson, Phospholipid transfer protein from bovine retina with high activity towards retinal rod disc membranes

$93(1978) 239$

99 (1979) 117

$96(1978) 207$

91 (1978) 265

91 (1978) 216

94 (1978) 81

93 (1978) 255

99 (1979) 152

97 (1979) 105

93 (1978) 348

100 (1979) 367

$100(1979) 99$

96 (1978) 152

$96(1978) \quad 59$

92 (1978) 346

$100(1979) 148$

95 (1978) 185

$100(1979) 286$

96 (1978) 111

96 (1978) 115

100 (1979) 321

100 (1979) 269

99 (1979) 361

97 (1979) 77

95 (1978) 57

92 (1978) 200

98 (1979) 377

Duniec, J.T., see M.J. Sculley

Dupont, Y., see N. Bennett

Dutton, P.L. and R.C. Prince, Equilibrium and disequilibrium in the ubiquinone-cytochrome $b-c_{2}$ oxidoreductase of Rhodopseudomonas sphaeroides

$98(1979) 229$

$91(1978) \quad 15$

Eady, R.R., D.J. Lowe and R.N.F. Thorneley, Nitrogenase of Klebsiella pneumoniae: A pre-steady state burst of ATP hydrolysis is coupled to electron transfer between the component proteins

95 (1978) 211

Earle, S.R., W.M. Anderson and R.R. Fisher, Evidence that reconsitituted bovine heart mitochondrial transhydrogenase functions as a proton pump

Ebel, J.P., see P. Carbon

Eberhardt, N.L., see S.-y. Cheng

Eckstein, F. and J.C. Foreman, Actions of adenosine and guanosine $3^{\prime}: 5^{\prime}$-cyclic phosphorothioates on histamine secretion

Edelstein, S., see M. Sheves

Edelstein, S., M. Sheves, Y. Mazur, A. Bar and S. Hurwitz, Synthesis and biological action of 3-deoxy-vitamin $D_{3}$ and 3-deoxy-25-hydroxyvitamin $D_{3}$

Edgerton, M.E., T.A. Moore and C. Greenwood, Salt reversal of the acid-induced changes in purple membrane from Halobacterium halobium

Edmondson, D.E., see W.C. Kenney

91 (1978) 21

94 (1978) 152

$100(1979) 113$

$91(1978) 182$

$96(1978) 75$

97 (1979) 241

95 (1978) 35

$97(1978) \quad 40$ 
Edwards, B.K., see G. Kranias

Edwards, C.A., see B.L. Trumpower

Edwards, J.A., see L.M. Garrick

Edwards, K., M. Nagashima, H. Dryburgh, A. Wykes and G. Schreiber, Secretion of proteins from liver cells is suppressed by the proteinase inhibitor $N$ - $\alpha$-tosyl-l-lysyl chloromethane, but not by tunicamycin, an inhibitor of glycosylation

Efendic, S., A. Nylén, A. Roovete and $\mathrm{K}$. Uvnäs-Wallensten, Effects of glucose and arginine on the release of immunoreactive somatostatin from the isolated perfused rat pancreas

Efimov, V.A., see Yu.A. Ovchinnikov

Egert, E., see W. Hillen

Eggler, E., see B. Rüstow

Egly, J.-M., Charge-transfer chromatography: an efficient method for separation of nucleosides and cyclic nucleotides on acriflavin Sephadex

Egozi, Y, see Y. Kloog

Ehmann, C., see D.H. Wolf

Ehmann, C, see D.H. Wolf

Ehnholm, C., see T. Kuusi

Ehrenberg, A., see T. Ljones

Ehresmann, B., see P. Carbon

Ehresmann, C., see P. Carbon

Ejiri, S.-i., K. Murakami and T. Katsumata, Elongation factor 1 from the silk gland of silkworm.

Reconstruction of EF-1 $M$ from its subunits, EF-1a and EF-1bc

Ejiri, S.-i., see K. Murakami

Ejiri, S.-i., Y. Naoki. K. Murakami and T. Katsumata, Exchangeability of silk gland elongation factor $1 \mathrm{~b}$ and pig liver elongation factor $1 \beta$ in polypeptide chain elongation

Elcombe, B., see J.A. Kulkoski

Eldor, A., sec A. Muhlrad

Elias, P., F. Lustig, T. Axberg, B. Akesson and U. Lagerkvist, Reading of the lysine codons in the MS 2 coat protein during protein synthesis in vitro

Elizarov, S.M., A.S. Stepanov, P.E. Felgenhauer and E.V. Chulitskaya, Involvement of RNA-binding proteins in the formation of informosomes in vivo

Embi, N., see D.B. Rylatt

Emmelot, P., see A.P. Steward

Endermann, R. and U. Henning, Nearest neighbors of major proteins in the outer membranes of Escherichia coli $\mathrm{K} 12$

Endo, Y., Deacetylation and deformylation of $\mathrm{N}$-acyl amino acids by kidney acylases

Engel, W.D., see G. von Jagow

Engeser, H., see F. Wieland

Eppenberger, U., see G. Kranias

Erdmann, E., see S. Soboll

Erecińska, M., see C. Barlow

Erickson, R.P., see B. Pegoraro

Eskov, A.P., see I.G. Kharitonenkov

Esmann, V., see C. Sand Petersen

Estabrook, R.W., see H. Kuthan

Estall, M.R., see J.A. Craft

Etherington, D.J., see P. Evans

Evans, M.C.W, see A.W. Rutherford

Evans, N.A., see J.F. Codington

Evans, P. and D.J. Etherington, Action of cathepsin N on the oxidized B-chain of bovine insulin

Exley, D. and R. Abuknesha, A. highly sensitive and specific enzyme-immunoassay method for oestradiol-17 $\beta$

Exton, J.H., see P.F. Blackmore

92 (1978) 357

$100(1979) \quad 13$

$93(1978) 109$

100 (1979) 269

92 (1978) 33

100 (1979) 341

94 (1978) 361

95 (1978) 225

93 (1978) 369

97 (1979) 265

91 (1978) 59

92 (1978) 121

98 (1979) 314

92 (1978) 81

94 (1978) 152

94 (1978) 152

92 (1978) 251

92 (1978) 255

95 (1978) 277

99 (1979) 183

92 (1978) 85

98 (1979) 145

93 (1978) 219

98 (1979) 76

100 (1979) 191

97 (1979) 339

95 (1978) 281

91 (1978) 121

100 (1979) 90

92 (1978) 357

100 (1979) 125

98 (1979) 9

95 (1978) 371

96 (1978) 120

99 (1979) 147

91 (1978) 343

98 (1979) 403

99 (1979) 55

$100(1979) 305$

99 (1979) 70

99 (1979) 55

91 (1978) 162

$100(1979) 117$

Fägerstam, L.G. and L.G. Pettersson, The cellulolytic complex of Trichoderma reesei QM 9414. An immunochemical approach

Fainaru, M. and R.J. Deckelbaum, Lipid binding protein (apolipoprotein A-1) contamination of high grade commercial albumins

98 (1979) 363

97 (1979) 171 
Faliks, D., see L. Reshef

97 (1979) 96

Falk, K.-E. and B. Karlsson, The interaction of protein and lipid in sonicated vesicles of cytochrome $c$ oxidase and phosphatidylcholine studied by ${ }^{1} \mathrm{H}$ NMR spectroscopy

$98(1979) 25$

Fardeau, M., see S. Carson

Farias, R.N., see E.M. de Melián

Farstad, M., see A.M. Bakken

Farver, O., M. Goldberg and I. Pecht, Circular dichroic spectrum of the laccase-peroxide derivative

Fasold, H., see K. Mann

Fasy, T.M., see J. Kallos

Favorova, O.O., see G.K. Kovaleva

Federman, P., see A. Schmidt

Feeney, J., see J. Degelaen

Fehr, S., F. Godt, K. Isono and D. Richter, A ribosome-independent stringent factor from Bacillus stearothermophilus and a low molecular weight substance inhibitory to its activity

Feigenson, G.W., see E. London

Feigenson, G.W., see P.B. Kingsley

Feigina, M.Yu., see Yu.A. Ovchinnikov

Feingold, D.S., see H.S. Prihar

Feix, G., see U. Wienand

Feizi, T., see R.A. Childs

Felgenhauer, P.E., see S.M. Elizarov

Fenichel, R., see D. Sarantakis

Fenske, H., see C.-U. von Mickwitz

Fenton, J.M., M.J. Pellin, Govindjee and K.J. Kaufmann, Primary photochemistry of the reaction center of photosystem I

Ferenci, T. and U. Klotz, Affinity chromatographic isolation of the periplasmic maltose binding protein of Escherichia coli

Fermandjian, S., see J. Vičar

Ferro, A.J., see R.E. Law

Fido, R.J., E.J. Hewitt, B.A. Notton, O.T.G. Jones and A. Nasrulhaq-Boyce, Haem of spinach nitrate reductase: Low temperature spectrum and mid-point potential

Filipowicz, W., Functions of the 5 '-terminal $\mathrm{m}^{7} \mathrm{G}$ cap in eukaryotic mRNA

Finazzi Agrò, A., see H.A. Kuiper

Finazzi Agro, A., see S. Stefanini

Finch, S.A.E., see A. Stier

Fine, R.E., A.L. Blitz and D.H. Sack, Characterization of anti-clathrin serum

Finne, J., see K.-A. Karlsson

Finne, J., see H. Rauvala

Fischman, A.J., M.W. Riemen and D. Cowburn, Averaging of $\phi_{2}$ and $\phi_{3}$ in [5-leucyl] -enkephalin: NMR study of two isotopic isomers

Fish, W.W., K. Orre and 1. Björk, The production of an inactive form of antithrombin through limited proteolysis by thrombin

Fishkes, H., see B.I. Kanner

Fisher, D., see A.M.J. Blow

Fisher, R.R., see S.R. Earle

Fiskum, G. and R.S. Cockrell, Ruthenium red sensitive and insensitive calcium transport in rat liver and

Ehrlich ascites tumor cell mitochondria

Flatmark, T., see T. Ljones

Flavin, M., see J. Nath

Fletcher, G.L, see C.L. Hew

Fletcher, P.L., jr, see L.D. Possani

Flink, I.L., J.H. Rader, S.K. Banerjee and E. Morkin, Atrial and ventricular cardiac myosins contain different heavy chain species

Flitney, F.W., see J. Singh

Flytzanis, C.N., see A. Alonso

Flytzanis, C.N., A. Alonso, C. Louis, L. Krieg and C.E. Sekeris, Association of small nuclear RNA with

97 (1979) 348

92 (1978) 143

$99(1979) \quad 47$

94 (1978) 383

92 (1978) 45

98 (1979) 347

95 (1978) 81

95 (1978) 257

98 (1979) 53

97 (1979) 91

96 (1978) 51

97 (1979) 175

100 (1979) 219

99 (1979) 106

98 (1979) 319

99 (1979) 175

93 (1978) 219

92 (1978) 153

98 (1979) 324

$100(1979) \quad 1$

94 (1978) 213

97 (1978) 275

99 (1979) 247

99 (1979) 180

96 (1978) 1

99 (1979) 317

100 (1979) 296

91 (1978) 109

94 (1978) 59

94 (1978) 413

97 (1979) 1

94 (1978) 236

98 (1979) 103

100 (1979) 175

94 (1978) 305

91 (1978) 21

92 (1978) 125

92 (1978) 81

95 (1978) 335

99 (1979) 337

91 (1978) 261

94 (1978) 125

91 (1978) 269

93 (1978) 351

96 (1978) 201 


\section{FEBS LETTERS}

Foekens, J.A., see E. Mulder

97 (1979) 260

Fohlman, J., see M. Belew

Fonyó, A. and E. Ligeti, Intramitochondrial phosphate is the source of protons in the response of liver mitochondria to cations

Fonyó, $A$. and $\mathbf{E}$. Ligeti, The role of intramitochondrial $\mathbf{P}_{\mathbf{i}}$ in stimulation of respiration by calcium and strontium

Foreman, J.C., see F. Eckstein

Forsén, S., see J.-E. Norne

Foulkes, J.G., see A. Burchell

Foulkes, J.G., see P. Cohen

Fox S.I. and J.R. Wisner, jr, The influence of heparin on LH- and dibutyryl- cAMP-stimulated testosterone production in vitro by adult rat testes

Fraenkel-Conrat, H., see M. Ikegami

Franèk, F., see L. Cser

Frangione, B., Y. Nakashima, W. Konigsberg and R.L. Wiseman, The amino acid sequence of the major coat protein subunit of the filamentous virus $\mathrm{Xf}$

Frank, G., J. Brunner, H. Hauser, H. Wacker, G. Semenza and H. Zuber, The hydrophobic anchor of small-intestinal sucrase isomaltase: $\mathrm{N}$-terminal sequence of the isomaltase subunit

Franklin, R.M., see R. Schäfer

Fransson, L.-A. and W. Lewis, Relationship between anticoagulant activity of heparin and susceptibility to periodate oxidation

Freedman, R.B., How many distinct enzymes are responsible for the several cellular processes involving thiol : protein-disulphide in terchange?

French, J.K., see C.C. Winterbourne

Frère, J.-M., see J. Degelaen

Frey, J. and K.-H. Röhm, The glucose-induced inactivation of aminopeptidase I in Saccharomyces cerevisiae Fridlender, B.R., see M.D. Walker

Friedberg, 1., see N. Porat

Friedman, G., O. Stein and Y. Stein, Stimulation of rat heart lipoprotein lipase activity by 4-aminopyrazolo[3,4-d]pyrimidine-induced reduction of plasma triacylglycerol

Friedman, Y., see S. Huprikar

Friedrich, W, see R. Bieganowski

Froesch, E.R., see J. Zapf

Froissart, C., P. Basset, P. Mandel and R. Massarelli, Choline acetyltransferase aggregates from human placenta and rat brain

Fromageot, P., see J. Huet

Fromageot, $\mathbf{P}$., see J. Vičar

Fry, C.H., see A.J. Williams

Fry, I., see T. Hase

Fry, M., see A. Kaftory

Fuchs, E., see M. Sarvas

Fuchs, O., see P. Ponka

Fuchs, R. and M. Peterlik, Vitamin D-induced transepithelial phosphate and calcium transport by chick jejunum: Effect of microfilamentous and microtubular inhibitors

Fuchs, R.P.P., see M. Leng

Fudyma, G., see C.F. Louis

Fujii, K., T. Kajiwara and H. Kurosu, Effect of vitamin B6 deficiency on the crosslink formation of collagen

Fujiki, K., A. Fukuda and Y. Okada, The absence of translational barrier between Caulobacter crescentus and Escherichia coli

Fuke, M. and $\mathrm{H}$. Busch, HindIII-sensitive sites present once in every four repeats of $E$ coRI-sensitive sites in Novikoff rat hepatoma DNA

Fukuda, A., see K. Fujiki

Fukuda, A., S. Koyasu and Y. Okada, Characterization of two flagella-related proteins form Caulobacter crescentus

Fukui, S., see S. Kawamoto

Fukui, S., see S. Kawamoto

Fuller, F.M., see D.J. Clarke

Fulton, D.V., see M.J. Selwyn

91 (1978) 302

96 (1978) 343

93 (1978) 289

91 (1978) 182

94 (1978) 410

92 (1978) 68

92 (1978) 287

98 (1979) 192

96 (1978) 197

93 (1978) 312

$96(1978) 381$

96 (1978) 183

94 (1978) 353

97 (1979) 119

97 (1979) 201

94 (1978) 269

98 (1979) 53

100 (1979) 261

92 (1978) 25

92 (1978) 9

100 (1979) 371

99 (1979) 167

97 (1979) 325

94 (1978) 43

$100(1979) 276$

94 (1978) 28

97 (1978) 275

97 (1979) 288

96 (1978) 41

99 (1979) 265

95 (1978) 76

97 (1979) 317

$100(1979) 357$

92 (1978) 207

93 (1978) 61

97 (1979) 193

$91(1978) \quad 81$

99 (1979) 136

91 (1978) 81

95 (1978) 70

96 (1978) 37

97 (1979) 253

$100(1979) 52$

$96(1978) 148$ 
Gal, A., N. de Groot and A.A. Hochberg, The effect of dimethylsulfoxide on ribosomal fractions from rat liver

Galdes, A., M. Vasak, H.A.O. Hill and J.H.R., Kägi, ${ }^{1}$ H NMR spectra of metallothioneins

Galdes, A., see A.E.G. Cass

Galmiche, J.M., see G. Girault

Gambacorta, A., see V. Zappia

Gambella, G.R., see G. Nanni

Gander, M., see R. Perez Bercoff

Garavito, R.M., see P. Argos

Garbay-Jaureguiberry, C., B.P. Roques, L. Delcambe, F. Peypoux and G. Michel, NMR conformational study of iturin $A$ an antibody from Bacillus subtilis

Garcia, A.F., see N.L. Kerber

Garcia-Patrone, M., Polypeptide synthesis inhibition by a factor inducing stabilization of $30 \mathrm{~S}-50 \mathrm{~S}$ ribosomal couples

Garcia-Ruiz, J.P., see R. Muñoz-Clares

Gardner, K.H., see S.A. Archer

Garrett, R.A., see W. Kühlbrandt

Garrett, R.A., see D.G. Bear

Garrick, L.M., J.A. Edwards and J.E. Hoke, The effect of hemin on globin synthesis and iron uptake by reticulocytes of the Belgrade rat

Garty, H., see D. Cahen

Gasaryan, K.G., E.D. Kuznetsova and V.Z. Tarantul, Are polyadenylated and non-polyadenylated giant HnRNA molecules transcribed from different sites in the genome?

Gasparov, V.S., R.M. Nalbandyan and H.Ch. Buniatian, Interaction of neurocuprein with adrenaline

Gassen, H.G., see W. Hillen

Gast, K., see P. Plietz

Gay, R., see G. Lefebvre

Gaye, P., see F. Hatey

Geelen, M.J.H., A.C. Beynen, R.Z. Christiansen, M.J. Lepreau-Jose and D.M. Gibson, Short-term effects of insulin and glucagon on lipid synthesis in isolated rat hepatocytes: covariance of acetyl-CoA carboxylase activity and the rate of ${ }^{3} \mathrm{H}_{2} \mathrm{O}$ incorporation into fatty acids

Geis, M., see D. Richter

Geissler, A.W., see A.R. Subramanian

Gelfand, V.I., see S.A. Kuznetsov

Gelfand, V.I., see S.A. Kuznetsov

Genot, A., J.P. Reboud, Y. Cenatiempo and A.J. Cozzone, Differential phosphorylation of basic and acidic ribosomal proteins by protein kinases bound to membrane-free rat liver polysomes

Georgalis, Y. and L. Giri, Shape of protein S5 from the $30 \mathrm{~S}$ subunit of Escherichia coli ribosome determined in two different ionic environments

Gergely, P., V. Dombrádi and G. Bot, Regulation of phosphoprotein phosphatase by phosphorylation of other proteins in skeletal muscle

Gerlo, E. and J. Charlier, Irreversible inactivation of arginyl-tRNA ligase by periodate-oxidized tRNA

Gershanovitch, V.N., see A.M. Umyarov

Ghandour, M.S., see B. Zalc

Ghazarian, J.G., see J.A. Kulkoski

Ghiggino, K.P., see A.G. Lee

Ghuysen, J.M., see J. Degelaen

91 (1978) 74

91 (1978) 74

96 (1978) 79

91 (1978) 158

$91(1978) 202$

99 (1979) 51

98 (1979) 355

96 (1978) 243

99 (1979) 203

96 (1978) 269

94 (1978) 25

92 (1978) 17

94 (1978) 311

95 (1978) 135

94 (1978) 161

93 (1978) 242

96 (1978) 306

$93(1978) \quad 19$

93 (1978) 151

94 (1978) 265

92 (1978) 263

99 (1979) 340

92 (1978) 343

94 (1978) 207

100 (1979) 99

93 (1978) 109

91 (1978) 131

94 (1978) 136

97 (1979) 37

94 (1978) 361

91 (1978) 227

$93(1978) \quad 55$

95 (1978) 252

95 (1978) 326

96 (1978) 247

99 (1979) 357

95 (1978) 339

95 (1978) 343

$99(1979) 261$

$95(1978) \quad 99$

93 (1978) 239

99 (1979) 25

96 (1978) 31

92 (1978) 92

99 (1979) 183

94 (1978) 171

98 (1979) 53 


\section{FEBS LETTERS}

Gibson, D.M., see M.J.H., Geelen

Giesel, M., see K. Mann

Giesen, M., see A.R. Subramanian

Giffhorn, F. and G. Gottschalk, Crystallization and subunit composition of citrate lyase of Rhodopseudomonas gelatinosa

Giordano, G., A. Graham, D.H. Boxer, B.A. Haddock and E. Azoulay, Characterization of the membrane-bound nitrate reductase activity of aerobically-grown chlorate-sensitive mutants of Escherichia coli $\mathrm{K} 12$

Girault, G. and J.M. Galmiche, Chlortetracycline as a fluorescent probe of the first nucleotide binding site of the coupling factor $\mathrm{CF}_{1}$ of spinach chloroplasts

Giri, L., see Y. Georgalis

Girit, E.Z., see C.A. Phillips

Girshovich, A.S. and T.V. Kurtskhalia, Elongation factor $\mathbf{G}$ interacts with both ribosomal subparticles

Giudicelli, Y., see R. Pecquery

Gladkikh, I.A., see L. Cser

Glaser, G., see L. Reshef

Glotov, B.O., A.V. Itkes, L.G. Nikolaev and E.S. Severin, Evidence for the close proximity of histones

$\mathrm{H} 1$ and $\mathrm{H} 3$ in chromatin of intact nuclei

Gnanam, A., see M. Krishnan

Gnemmi, E., see M.J. O'Sullivan

Gnoni, G.V., C. Landriscina and E. Quagliariello, Mechanism of triiodothyronine stimulation on microsomal fatty acid chain elongation synthesis in rat liver

Gocke, E., see C. Tsopanakis

Godt, F., see S. Fehr

Gogia, Z.V., see N.N. Khechinashvilli

Goh, E.H., see F. Schroeder

Goheer, M.A., see M.A. Baxter

Goldberg, M., see O. Farver

Goldblum, A., D. Perahia and A. Pulleman, Hydration scheme of the complementary base-pairs of DNA

Gomes, S.L., L. Mennucci and J.C. C. Maia, A calcium-dependent protein activator of mammalian cyclic nucleotide phosphodiesterase from Blastociadiella emersonii

Gómez-Fernández, J.C., see D. Chapman

Gómez-Fernández, J.C., F.M. Goni, D. Bach, C. Restall and D. Chapman, Protein-lipid interactions: A study of $\left(\mathrm{Ca}^{2+}+\mathrm{Mg}^{2+}\right)$ ATPase reconstituted with synthetic phospholipids

Goñi, F.M., see D. Chapman

Goñi, F.M., see J.C. Gómez-Fernández

Goodall, A.H., see A.M.J. Blow

Goodwin, G.H., see J.M. Walker

Goody, R.S., see K. Akasaka

Gopher, A., see G. Schreiber

Goris, J., G. Defreyn and W. Merlevede, Resolution of the ATP-Mg-dependent phosphorylase phosphatase from liver into a two protein component system

Gorissen, H., G. Aerts and P. Laduron, Characterization of digitonin-solubilized muscarinic receptor from rat brain

Gorissen, H., G. Aerts and P. Laduron, Characterization of solubilized dopamine receptors from dog striatum

Got, R., sce G. Azzar

Gottschalk, G., see F. Giffhorn

Götz, R., see L.R. Schwarz

Gould, J.M., Dithiol-specific reversal of triphenyltin inhibition of $\mathrm{CF}_{\mathrm{o}}$-catalyzed transmembrane proton transfer in chloroplasts

Gould, J.M. and C. Underwood, $\mathrm{Hg}^{2+}$-induced turnover of the chloroplast ATP synthetase complex in the absence of ADP and phosphate

Govindjee, see D. Wong

Govindjee, see J.M. Fenton

Gozes, I. and C. Richter-Landsberg, Identification of tubulin associated with rat brain myelin

Gozes, I., see M.D. Walker

95 (1978) 326

92 (1978) 45

99 (1979) 357

96 (1978) 175

95 (1978) 290

95 (1978) 135

95 (1978) 99

94 (1978) 115

92 (1978) 203

98 (1979) 241

93 (1978) 312

97 (1979) 96

91 (1978) 149

97 (1979) 322

95 (1978) 311

94 (1978) 179

93 (1978) 297

97 (1979) 91

95 (1978) 270

97 (1979) 233

97 (1979) 27

94 (1978) 383

91 (1978) 213

99 (1979) 39

98 (1979) 24

98 (1979) 224

98 (1979) 211

98 (1979) 224

94 (1978) 305

100 (1979) 394

96 (1978) 287

96 (1978) 357

99 (1979) 279

96 (1978) 64

100 (1979) 281

96 (1978) 164

96 (1978) 175

98 (1979) 203

94 (1978) 90

95 (1978) 197

97 (1979) 373

100 (1979) 1

95 (1978) 169

98 (1979) 187 
Gozes, I. and U.Z. Littauer, The $\alpha$-subunit of tubulin is preferentially associated with brain presynaptic membrane

Gräber, P., A. Zickler and H.-E. Åkerlund, Electric evidence for the isolation of inside-out vesicles from spinach chloroplasts

Graca-Miguel, M., see W. Hoffman

Graf, H, see H. Kuthan

Graf, T. and W. Sebald, The dicyclohexylcarbodiimide-binding protein of the mitochondrial ATPase complex from beef heart. Isolation and amino acid composition

Graham, A., see G. Giordano

Grand, R.J.A. and S.V. Perry, The amino acid sequence of the troponin C-like protein (modulator protein) from bovine uterus

Grande, H.J. and K.R. van der Ploeg, Tricine radicals as formed in the presence of peroxide-producing enzymes Granier, C., see C. Ronin

Granon, S., see H. Sari

Granot, J. and K. Rosenheck, On the role of ATP and divalent metal ions in the storage of catecholamines.

${ }^{1}$ H NMR studies of bovine adrenal chromaffin granules

Grantham, R., Viral, prokaryote and eukaryote genes contrasted by mRNA sequence indexes

Gratzer, W.B., see J.C. Pinder

Grau, E.M., G.V. Marathe and S.S. Tate, Rapid purification of rat kidncy brush borders enriched in $\gamma$-glutamyl transpeptidase

Grebing, C., see H. Löw

Greenwood, C., see M.E. Edgerton

Green, M.R., H.A.O. Hill, M.J. Okolow-Zubkowska and A.W. Segal, The production of hydroxyl and superoxide radicals by stimulated human neutrophils - measurements by EPR spectroscopy

Greuer, B., see B. Wittmann-Liebold

Griffiths, W.T., see R.E. Mapleston

Grigoriev, V.B., see I.G. Kharitonenkov

Grinius, L., see E. Kalasauskaite

Grinstein, S., see A. Klip

Gross, H.J., see V.V. Vlassov

Gross, H.J., see H.L. Sänger

Grunberg-Manago, M., see M. Laughrea

Grunow, M. and W. Schopp, Inactivation of crystalline yeast alcohol dehydrogenase by enzyme-bound proteolytic activity

Grunst, J., see M. Wicklmayr

Guay, M., see M. Davril

Gubler, U., T. Wyler and R. Braun, The gene for the $26 \mathrm{~S}$ rRNA in Physarum contains two insertions

Gudkov, A.T., L.G. Tumanova, S.Yu. Venyaminov and N.N. Khechinashvili, Stoichiometry and properties of the complex between ribosomal proteins L7 and L10 in solution

Guerrieri, F., see G. Izzo

Guétard, D., see M.-E. Mouttet

Guidoni, L., see R. Strom

Guinovart, J.J., see C.J. Ciudad

Gulyaeva, J.G., see S.A. Kuznetsov

Gurari-Rotman, D., M. Revel, B. Tartakovsky, S. Segal, T. Hahn, Z. Handzel and S. Levin,

Lymphoblastogenesis in Down's syndrome and its inhibition by human interferon

Gurrola, M.A.H., see L.D. Possani

Gutman, M., see G. Schreiber

Gutnick, D., see D. Ralt

Gutweniger, H., see R. Bisson

Guy, P.s. S. Law and G. Hardie, Mammalian fatty acid synthetase: evidence for subunit identity and specific removal of the thioesterase component using elastase digestion

96 (1978) 233

95 (1978) 31

$91(1978) 343$

94 (1978) 218

95 (1978) 290

92 (1978) 137

95 (1978) 352

96 (1978) 179

95 (1978) 229

95 (1978) 45

95 (1978) 1

92 (1978) 278

98 (1979) 91

91 (1978) 166

95 (1978) 35

100 (1979) 23

95 (1978) 91

92 (1978) 168

$96(1978) 120$

99 (1979) 287

99 (1979) 91

94 (1978) 157

99 (1979) 117

91 (1978) 265

94 (1978) 375

98 (1979) 61

98 (1979) 128

100 (1979) 347

93 (1978) 215

93 (1978) 320

100 (1979) 107

96 (1978) 45

99 (1979) 321

95 (1978) 343

94 (1978) 187

91 (1978) 261

96 (19.78) 357

91 (1978) 85

92 (1978) 219

94 (1978) 33

Haase, W., see K. Mann

Haberkorn, R., see M.E. Michel-Beyerle

Haddock, B.A., see J.C. Cox

Haddock, B.A., see G. Giordano

92 (1978) 45

100 (1979) 9

93 (1978) 261

95 (1978) 290 


\section{FEBS LETTERS}

Hadjiolov, A.A., see Z.E. Mateeva

94 (1978) 342

Hagar, W.G., see R.H. Clarke

99 (1979) 207

Hagiwara, H., see H. Hasebe

Hagmann, J., I. Weiler and E. Waelti, Effects of low density lipoproteins on lymphocyte stimulation

Hahlbrock, K., see F. Kreuzaler

Hahn, T., see D. Gurari-Rotman

Hakim, J., see M. Torres

Hales, C.N., Proteolysis and the evolutionary origin of polypeptide hormones

Hall, D.O., see L.E.A. Henry

Hall, D.O., see T. Hase

Hall, D.O., see M.J. Llama

Hall, K., see H. Löw

Hall, L.M., R.W. von Borstel, B.C. Osmond, S.D. Hoeltzli and T.H. Hudson, Genetic variants in an acetylcholine receptor from Drosophila melanogaster

Hall, N.P. and N.E. Tolbert, A. rapid procedure for the isolation of ribulose bisphosphate carboxylase/ oxygenase from spinach leaves

Hallenbeck, P.C. and J.R. Benemann, Characterization and partial purification of the reversible hydrogenase of Anabaena cylindrica

Halliday, M.I. and G.B. Wisdom, A competitive enzyme-immunoassay using labelled antibody

Halliwell, B., Superoxide-dependent formation of hydroxyl radicals in the presence of iron chelates: is it a mechanism for hydroxyl radical production in biochemical systems?

Halliwell, B., Superoxide-dependent formation of hydroxyl radicals in the presence of iron salts. Its role in degradation of hyaluronic acid by a superoxide-generating system

Hamana, K. and S. Matsuzaki, Occurrence of sym-homospermidine in the Japanese newt, Cynops pyrrhogaster pyrrhogaster

Hames, B.D., see P. Cappuccinelli

Hames, B.D., see M. Bownes

Hammarström, S., see P. Wlodawer

Hammarström, S., see J. Å. Lindgren

Han, K.-K., see M. Davril

Hanada, Y., see A. Razzaque

Hancock, I.C., see F.M. Roberts

Handzel, Z., see D. Gurari-Rotman

Hanei, M., see P. Argos

Hansson, L., see S. Ohlson

Hardie, D.G. and P. Cohen, The regulation of fatty acid biosynthesis: simple procedure for the purification of acetyl CoA carboxylase from lactating rabbit mammary gland, and its phosphorylation by endogenous cyclic AMP-dependent and independent protein kinase activities

Hardie, G., see P. Guy

Harding, J.J., see M.J.C. Crabbe

Harding, J.J. and M.J.C. Crabbe, Collagen crosslinking: isolation of a dimeric crosslinked peptide of $\alpha 1-$ CB6 from bovine corneal and scleral collagens

Hare, F. and C. Lussan, Mean viscosities in microscopic systems and membrane bilayers: a semi-empirical general basis applicable to different kinds of extrinsic probes

Harel, S., see E. Yavin

Häring, H.U., W. Kemmler, R. Renner and K.D. Hepp, Initial lag-phase in the action of insulin on glucose transport and CAMP levels in fat cells

Harris, J.I., see M.J. Runswick

Harris, J.I., see M.J. Runswick

Harrison, J.E., B.D. Watson and J. Schultz, Myeloperoxidase and singlet oxygen: a reappraisal

Harrison, P.M., see A. Treffry

Harrison, P.M. see A. Treffry

Harper, W.G., see M.D. Brand

Hartmann, H.-J., see U. Weser

Hartmann, S., J. Neeff, U. Heer and D. Mecke, Arenaemycin (pentalenolactone): a specific inhibitor of glycolysis

95 (1978) 295

97 (1979) 230

94 (1978) 175

94 (1978) 187

97 (1979) 50

94 (1978) 10

93 (1978) 327

96 (1978) 41

98 (1979) 342

91 (1978) 166

95 (1978) 243

96 (1978) 167

94 (1978) 261

96 (1978) 298

92 (1978) 321

96 (1978) 238

99 (1979) 325

91 (1978) 153

96 (1978) 327

97 (1979) 32

98 (1979) 247

98 (1979) 128

93 (1978) 335

97 (1979) 211

94 (1978) 187

93 (1978) 19

93 (1978) 5

91 (1978) 1

94 (1978) 33

97 (1979) 189

100 (1979) 351

94 (1978) 231

97 (1979) 151

95 (1978) 177

92 (1978) 365

94 (1978) 380

92 (1978) 327

95 (1978) 221

100 (1979) 33

95 (1978) 125

97 (1979) 311

93 (1978) 339 
Hase, T., S. Wakabayashi, H. Matsubara, D. Ohmori and K. Suzuki, Pseudomonas ovalis ferredoxin: similarity to Azotobacter and Chromatium ferredoxins

Hase, T., S. Wakabayashi, K. Wada, H. Matsubara, F. Jüttner, K.K. Rao, I. Fry and D.O. Hall, Cyanidium caldarium ferredoxin: a red algal type?

Hasebe, H., S. Yamazaki, Y. Tamaura, H. Hagiwara and Y. Inada, Inhibition of chloroplast adenosine triphosphatase activity by basic proteins and peptides

Haselbacher, G.K., R.E. Humbel and G. Thomas, Insulin-like growth factor: insulin or serum increase phosphorylation of ribosomal protein $\mathbf{S 6}$ during transition of stationary chick embryo fibroblasts into early $G$, phase of the cell cycle

Hasselbach, W, see B. Rauch

Hassinen, I.E., see M.A. Lehtonen

Hatanaka, H., H. Thoenen and U. Otten, Nerve growth factor-mediated selective induction of ornithine decarboxylase in rat pheochromocytoma; a cyclic AMP-independent process

Hatano, H., see A. Yamada

Hatey, F. and P. Gaye, Inhibition of translation in reticulocyte lysate by the mycotoxin patulin

Hauser, H., see G. Frank

Haverkamp, J, see D. Leger

Haverkate, F., see W. Niewenhuizen

Hawke, J.C., see J.W.A. McKee

Hawthorne, J.N., see M.R. Pickard

Hay, C., J.A. Rooke and E.R. Skinner, Fractionation of rat high density lipoprotein by affinity chromatography

Hayashi, D., see K. Kato

Hayman, E., see E. Ruoslahti

Haynes, J.R., V.F. Kalb, jr, P. Rosteck, jr and J.B. Lingrel, The absence of a precursor larger than $16 \mathrm{~S}$ to globin mRNA

Heer, U., see S. Hartmann

Heidmann, T., A. Sobel and J.-P. Changeux, Recovery of allosteric interactions between a fluorescent cholinergic agonist and local anesthetics after removal of the detergent from cholate-solubilized membrane fragments rich in acetylcholine receptor

Heimberg, M., see F. Schroeder

Heidrich, H.-G., S.P.J. Albracht and D. Bäckström, Two iron sulfur centers in mitochondrial outer membranes from beef heart as prepared by free-flow electrophoresis

Heldt, H.W., C.J. Chon and G.H. Lorimer, Phosphate requirement for the light activation of ribulose-1,5-bisphosphate carboxylase in intact spinach chloroplasts

Heldt, H.W., see S. Soboll

Hellingwerf, K.J., J.J. Schuurmans and H.V. Westerhoff, Demonstration of coupling between the protonmotive force across bacteriorhodopsin and the flow through its photochemical cycle

Helwig, J.J., see B. Zalc

Hems, D.A., see P.D. Whitton

Henco, K., see H.L. Sänger

Henke, R.R. and R. Wahnbaeck-Spencer, Variations in $\beta$-aspartate kinase activity during the development of maize endosperm

Henkel, J., see G.F. Wildner

Hennemann, G., see E.P. Krenning

Hennen, G., see G. Maghuin-Rogister

Henning, U., see R. Endermann

Henquin, J.C., see H.P. Meissner

Henry, L.E.A., J.M. Palmer and D.O. Hall, The induction of histochemically-detectable superoxide dismutase ( $\mathrm{Cu} / \mathrm{Zn}$ type) bands on acrylamide gels

Henry, M.F, and P.M. Vignais, Induction by cyanide of cytochrome $d$ in the plasma membrane of Paracoccus denitrificans

Hepp, K.D., J. Rinninger, J. Langley and R. Renner, Inhibition of catecholamine-stimulated adenylate cyclase in fat cells by local anaesthetics

Hepp, K.D., see H.U. Häring

Herczeg, T, see S. Demeter

Herlin, T., see C. Sand Petersen

Herries, D.G., see A.J. Pope

91 (1978) 315

$96(1978) \quad 41$

$95(1978) 295$

$100(1979) 185$

$93(1978) 65$

99 (1979) 162

92 (1978) 313

$93(1978) \quad 16$

95 (1978) 252

96 (1978) 183

$93(1978) 255$

98 (1979) 257

94 (1978) 273

$93(1978) 78$

91 (1978) 30

99 (1979) 172

97 (1979) 221

91 (1978) 173

93 (1978) 339

94 (1978) 397

97 (1979) 233

95 (1978) 314

92 (1978) 234

100 (1979) 125

92 (1978) 181

92 (1978) 92

98 (1979) 85

99 (1979) 117

99 (1979) 113

91 (1978) 99

91 (1978) 113

100 (1979) 121

97 (1979) 339

94 (1978) 87

93 (1978) 327

$100(1979) \quad 41$

91 (1978) 325

95 (1978) 177

100 (1979) 321

99 (1979) 147

93 (1978) 174 
Herrmann, B., see A. Holstege

Herry, P. and V. Keil-Dlouha, Inhibition of Achromobacter collagenase by bromoacetone and by zinc ions

Hesketh, J.E., N. Virmaux and P. Mandel, Evidence for a cyclic nucleotide-dependant phosphorylation of retinal myosin

Hess, B., see R. Korenstein

Hess, B. and D. Kuschmitz, Kinetic interaction between aromatic residues and the retinal chromophore of bacteriorhodopsin during the photocycle

Heumann, H. and W. Zillig, Continuous monitoring of transcription by light scattering

Heumann, W., see P. Westermann

Hew, C.L. and G.L. Fletcher, The role of pituitary in regulating antifreeze protein synthesis in the winter flounder

Hewitt, E.J., see J.M. Maldonado

Hewitt, E.J., see R.J. Fido

Heymann, E. and R. Mentlein, Liver dipeptidyl aminopeptidase IV hydrolyzes substance P

Heyn, M.P., see N.A. Dencher

Hidaka, S., K Shimotohno, K.-I. Miura, Y. Takana and S. Kubo, Nucleotide sequence near the 5'-terminal of cucumber mosaic virus RNA no. 5 segment

Higginbottom, L., see J.F.Y. Hoh

Hildenbrand, K., see A.-C. Roche

Hill, H.A.O, see A. Galdes

Hill, H.A.O., see A.E.G. Cass

Hill, H.A.O, see M.R. Green

Hillen, W., E. Egert, H.J. Lindner and H.G. Gassen, Restriction or amplification of wobble recognition: The structure of 2-thio-5-methylaminomethyluridine and the interaction of odd uridines with the anticodon loop backbone

Hilz, H., see M. Schumacher

Hilz, $H$, see W. Weber

Hind, G., see D. Crowther

Hinz, R., see B. Kaina

Hirabayashi, Y, T. Taki and M. Matsumoto, Tumor ganglioside - natural occurrence of $\mathrm{GM}_{1 b}$

Hirth, K.P., see M. Sarvas

Hiyama, T., H.Y. Tsujimoto and D.I. Arnon, Photoreduction of membrane-bound paramagnetic component

$\mathrm{X}$ by water as electron donor

Hjalmarsson, S.-G., see J. Sjödahl

Hochberg, A.A., see A. Gal

Hodi, J., see B. Rüstow

Hoeltzli, S.D., see L.M. Hall

Hoffman, R.M., L.B. Margolis and L.D. Bergelson, Binding and entrapment of high molecular weight DNA by lecithin liposomes

Hoffmann, W., M. Graca-Miguel, P. Barnard and D. Chapman, Evidence for conformational transitions in bacteriorhodopsin

Hoffmann, M., see K. Kumakura

Hoh, J.F.Y., G.P.S. Yeoh, M.A.W. Thomas and L. Higginbottom, Structural differences in the heavy chains of rat ventricular myosin isoenzymes

Hoh, J.F.Y., Developmental changes in chicken skeletal myosin isoenzymes

Høj Nielsen, A., see K. Poulsen

Hoke, J.E, see L.M. Garrick

Holladay, C.R., see J.L. Morgan

Hollander, V.P., see J. Kallos

Hollander, Z., see F. Kohen

Holm, J., see G. Cederblad

Holmberg, I., see J.I. Pedersen

Holmsen, H., see J.W.N. Akkerman

Holstege, A., B. Herrmann and D.O.R. Keppler, Increased formation of nucleotide derivatives of 5-fluorouridine in hepatoma cells treated with inhibitors of pyrimidine synthesis and D-galactosamine

Holstein, A.F., see M. Schumacher $\begin{array}{rr}95(1978) & 361 \\ 95(1978) & 65 \\ & \\ 94(1978) & 357 \\ 93(1978) & 266 \\ & \\ 100(1979) & 334 \\ 91(1978) & 351 \\ 97(1979) & 101 \\ & \\ 99(1979) & 337 \\ 93(1978) & 169 \\ 99(1979) & 180 \\ 91(1978) & 360 \\ 96(1978) & 322 \\ & \\ 98(1979) & 115 \\ 97(1979) & 330 \\ 93(1978) & 91 \\ 92(1978) & 17 \\ 94(1978) & 311 \\ 100(1979) & 23\end{array}$

94 (1978) 361

91 (1978) 333

99 (1979) 62

98 (1979) 386

96 (1978) 19

100 (1979) 253

95 (1978) 76

98 (1979) 381

92 (1978) 22

94 (1978) 25

95 (1978) 225

95 (1978) 243

93 (1978) 365

95 (1978) 31

93 (1978) 231

97 (1979) 330

98 (1979) 267

98 (1979) 135

93 (1978) 109

93 (1978) 141

98 (1979) 347

100 (1979) 137

98 (1979) 57

98 (1979) 394

100 (1979) 286

95 (1978) 361

91 (1978) 333 
Hölttä, E., P. Pohjanpelto and J. Jänne, Dissociation of the early antiproliferative action of methylglyoxal bis(guanylhydrazone) from polyamine depletion: A comparison of the effects of DL- $\alpha$-difluormethyl ornithine and methylglyoxal bis(guanylhydrazone) on the growth of human fibroblasts

Holwerda, R.A., see J.D. Clemmer

Holỳ, A., see J. Jonák

Honeybourne, C.L., J.T. Jackson and O.T.G. Jones, The interaction of mitochondrial ferrochelatase with a range of porphyrin substrates

Hoppe, I., see R. Paulsen

Hori, H., see K. Nagai

Horst, M.N., G. Baumbach and R.M. Roberts, Two-dimensional electrophoretic analysis of concanavalin-A binding components in the plasma membranes of Chinese hamster fibroblasts

Horvath, G., see S. Demeter

Horvath, 1., K. Tihanyi, S. Szeberényi and S. Otani, Effect of roseoflavin on microsomal drug-metabolizing enzyme system

Howell, R.M., H. Rezvan and P.M. Scopes, Conformational transitions of thromboplastin apoprotein from pig brain

Hsiang, M.W., T.J. White and J.E. Davies, $\mathrm{NH}_{2}$-terminal sequence of the aminoglycoside acetyltransferase (3)-I mediated by plasmid RIP 135

Huang, T.-S. and E.G. Krebs, Effect of proteases on the structure and activity of rabbit skeletal muscle glycogen synthetase

Huber, S.C., Substrates and inorganic phosphate control: the light activation of NADP-glyceraldehyde-3phosphate dehydrogenase and phosphoribulokinase in barley (Hordeum vulgare) chloroplasts

Hudecek, J., P. Anzenbacher and V. Kalous, Interaction of insulin with metal(II) ions

Hudson, L., see D. Snary

Hudson, T.H., see L.M. Hall

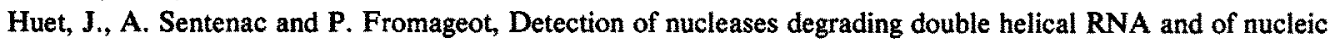
acid-binding proteins following SDS gel electrophoresis

Hughes, M.E., see B. Bloj

Hughes, R.J., see S.R. Ayad

Huisman, T.H.J., The hemoglobin P-Galveston-Hb-C condition in members of a black family from South Carolina

Hülsmann, W.C., see H. Jansen

Hultin, $T$., see P. Westermann

Humbel, R.E., see G.K. Haselbacher

Hunt, T., see R.J. Jackson

Huprikar, S., M. Lang, Y. Friedman and G. Burke, Parallel regulation of cyclic AMP-dependent protein kinase and phosphoprotein phosphatase in rat thyroid

Huq, S. and J.M. Palmer, Oxidation of durohydroquinone via the cyanide-insensitive respiratory pathway in higher plant mitochondria

Huq, S. and J.M. Palmer, Isolation of a cyanide-resistant duroquinol oxidase from Arum maculatum mitochondria

Hurwitz, S., see S. Edelstein

Hutson,N.J. and P.J. Randle, Enhanced activity of pynuate dehydrogenase kinase in rat heart mitochondria in alloxan-diabetes or starvation

Huybrechts-Godin, G. and G. Vaes, Secretion of a latent neutral proteinase that degrades cartilage proteoglycans by skin and synovial fibroblasts in culture

Hynie, S. and J. Smrt, Effects of adenosine 5'-phosphate esters with lipoid hydroxycompounds (adenosine nucleolipids) on the activity of enzymes of cyclic AMP systems

Ichida, S., see K. Sobue

Ichihara, S., see F. Yu

Iida, H., K. Ikehara and Y. Okada, Differential transcription of fd RFI DNA by Caulobacter crescentus and Escherichia coli RNA polymerases

lizuka, T., see H. Shimada

Ikeba, $\mathrm{K}$, see N. Sone

Ikegami, M. and H. Fraenkel-Conrat, The RNA-dependent RNA polymerase of cowpea

Ikehara, K., see H. lida

97 (1979) 9

91 (1978) 346

98 (1979) 329

98 (1979) 207

96 (1978) 55

93 (1978) 275

100 (1979) 385

100 (1979) 321

$98(1979) \quad 49$

97 (1979) 23

92 (1978) 97

$98(1979) \quad 66$

92 (1978) 12

$100(1979) 374$

100 (1979) 166

95 (1978) 243

94 (1978) 28

96 (1978) 87

$95(1978) 165$

94 (1978) 68

98 (1979) 299

97 (1979) 101

100 (1979) 185

93 (1978) 235

$99(1979) 167$

92 (1978) 317

95 (1978) 217

97 (1979) 241

92 (1978) 73

91 (1978) 242

94 (1978) 339

99 (1979) 199

$100(1979) 71$

99 (1979) 346

98 (1979) 290

97 (1979) 61

96 (1978) 197

99 (1979) 346 


\section{FEBS LETTERS}

Ikehara, M., see M. Sugiura

Imahori, K., see Y. Ohno-Iwashita

Imai, F., see K. Satoh

Imedidze, E.A., I.E. Drobinskaya, T.M. Kerimov, E.K. Ruuge and I.A. Kozlov, $\mathrm{Mn}^{2+}$ inside submitochondrial particles as a tool for studying the functional state of the mitochondrial membrane

Inada, Y., see H. Hasebe

Ingledew, W.J., see J.C. Cox

Ingledew, W.J., see M.D. Brand

Inglis, A.S., P.M. Strike, W.C. Osborne and R.W. Burley, Sequenator determination of the amino acid sequence of apovitellenin I from turkey's egg yolk: Use of a stationary reaction cup during peptide bond. cleavage

Ishihara, $\mathbf{H}$. and $\mathbf{K}$. Shimura, Thiazoline ring formation in bacitracin biosynthesis

Ishikawa, C., S. Nakamura, K. Watanabe and K. Takahashi, The amino acid sequence of adzuki bean proteinase inhibitor I

Ishimura, Y., see H. Shimade

Ishimura, $Y$, see E. Tachikawa

Ishmuratov, B.Kh., see A.I. Biryukov

Isono, K., see S. Fehr

Itkes, A.V., see B.O. Glotov

Ito, E., see S. Kawagishi

Itoh, N., T. Sei, K. Nose and H. Okamoto, Glucose stimulation of the proinsulin synthesis in isolated pancreatic islets without increasing amount of proinsulin mRNA

Itoh, T. and B. Wittmann-Liebold, The primary structure of Bacillus subtilis acidic ribosomal protein B-L9 and its comparison with Escherichia coli proteins $\mathrm{L} 7 / \mathrm{L} 12$

Itoh, T. and B. Wittmann-Liebold, The primary structure of protein 44 from the large subunit of yeast ribosomes Ivell, R., see G. Sander

Ivey, D.E., see P.E.B. Reilly

Izumi, F., see E. Tachikawa

Izumiya, N., see $A$. Yasutake

Izzo, G., F. Guerrieri and S. Papa, On the mechanism of inhibition of the respiratory chain by 2-heptyl-4hydroxyquinoline- $N$-oxide

Jackson, J.B., see K.M. Petty

Jackson, J.T., see C.L. Honeybourne

Jackson, R.J. and T. Hunt, The use of hexose phosphates to support protein synthesis and generate $\left[\gamma^{32}\right.$ P]ATP in reticulocyte lysates

Jackson, R.L., J. Westerman and K.W.A. Wirtz, Complete exchange of phospholipids between microsomes and plasma lipoproteins mediated by liver phospholipid-exchange proteins

Jacquemin, C., see S. Champion

Jacquot, J.-P., J. Vidal, P. Gadal and P. Schürmann, Evidence for the existence of several enzyme-specific thioredoxins in plants

Jaffé, W.G., see D.S. Seidl

Jain, S.K., M.G. Pluskal and S. Sarkar, Thermal chromatography of eukaryotic messenger ribonucleoprotein particlus on oligo-(dT)-cellulose: Evidence for common mRNA-associated proteins in various cell types

Jakubowski, H., Valyl-tRNA synthetase from yellow lupin seeds. Instability of enzyme-bound noncognate adenylates versus cognate adenylate

Jänne, J., see E. Hölttä

Jansen, H., C. Kalkman, A.J. Zonneveld and W.C. Hülsmann, Secretion of triacylglycerol hydrolase activity by isolated parenchymal rat liver cells

Janson, J.-C., see M. Belew

Jantschak, J., see C. Schroeder

Jayle, M.-F., see P. Urios

Jeanloz, R.W., see J.F. Codington

Jebeleanu, G., see L.D. Ngoc

Jeffery, S. and N. Spencer, Changes in carbonic anhydrase isoenzyme content accompanying differentiation in rabbit erythroid cells

$\begin{array}{rrr}97(1979) & 73 \\ 100(1979) & 249 \\ 95(1978) & 239 \\ & & \\ 96(1978) & 115 \\ 95(1978) & 295 \\ 93(1978) & 261 \\ 95(1978) & 125\end{array}$

97 (1979) 179

99 (1979) 109

99 (1979) 97

98 (1979) 290

100 (1979) 331

91 (1978) 249

97 (1979) 91

91 (1978) 149

97 (1979) 20

93 (1978) 343

96 (1978) 392

96 (1978) 399

98 (1979) 111

97 (1979) 141

100 (1979) 331

100 (1979) 241

93 (1978) 320

97 (1979) 367

98 (1979) 207

93 (1978) 235

94 (1978) 38

92 (1978) 156

96 (1978) 243

92 (1978) 245

97 (1979) 84

95 (1978) 235

97 (1979) 9

98 (1979) 299

91 (1978) 302

93 (1978) 33

94 (1978) 54

99 (1979) 70

97 (1979) 65

95 (1978) 323 
Joachimiak, A., J. Barciszewski, T. Twardowski, M. Barciszewska and M. Wiewiórowski, Purification and properties of methionyl-tRNA synthetase from yellow lupine seeds

$93(1978) 51$

Job, D., C. Cochet, F. Pirollet and E.M. Chambaz, A new specific endogenous inhibitor of a cyclic nucleotide-independent (G-type) protein kinase

Johannson, B.G., see P.M. Johnson

Johns, E.W., see J.M. Walker

Johnson, A.W., see O.C. Wallis

Johnson, M.E., A temperature-induced variation in the intrinsic hyperfine separation of a tightly bound nitroxide spin label

Johnson, M.H., see W.F. Moó-Penn

Johnson, P.M., P.M. Scopes, B.G. Solheim and B.G. Johannson, Comparative circular dichroism studies on human $\beta_{2}$-microglobulin

Jollès, J., see F. Boulay

Jollès, P., see J.-P. Périn

Jollès, P., see F. Boulay

Jonák, J., I. Rychlik, J. Smrt and A. Holý, The binding site for the 3'-terminus of aminoacyl-tRNA in the molecule of elongation factor $\mathrm{T}_{\mathbf{u}}$ from Escherichia coli

Jones, E.A., see C.J. Steer

Jones, O.T.G., see C.L. Honeybourne

Jones, O.T.G., see R.J. Fido

Jönsson, B., see E. Clementi

Jørgensen, O.S. and K. Mikoshiba, The brain-specific proteins D1, D2 and D3 in the cerebellum of staggerer, reeler and weaver mutant mice

Jortner, J. and J. Ulstrup, Molecular tunnelling in carbon monoxide binding to hemoglobin

Joshi, S., R.R. Murfitt and D.R. Sanadi, Further observations on coupling factor A

Jue, D.L., see W.F. Moo-Penn

Jungmann, R.A., see G. Kranias

Jutisz, M., see R. Counis

Jüttner, F., see T. Hase

Kafina, M., see J. Schmidt

Kaftory, A., P. Weisman-Shomer and M. Fry, Nuclear protein from cultured hepatoma cells preferentially inhibits copying of denatured DNA by isolated chromatin

Kagamiyama, H., see T. Yagi

Kagawa, Y., see N. Sone

Kägi, J.H.R., see A. Galdes

Kahane, I., see A. Muhlrad

Kaina, B., R. Hinz and I. Schubert, Organization of 5 S RNA genes in Vicia faba

Kajiwara, T., see K. Fujii

Kakimoto, T, see T. Shibatani

Kakiuchi, S., see K. Sobue

Kalasauskaite, E. and L. Grinius, The role of energy-yielding ATPase and respiratory chain at early stages of bacteriophage $\mathrm{T} 4$ infection

Kalb, V.F., jr, see J.R. Haynes

Kalb (Gilboa), A.J., see M. Shoham

Kalkman, C., see H. Jansen

Kallos, J., T.M. Fasy, V.P. Hollander and M.D. Bick, Estrogen receptor can distinguish among various halodeoxyuridine-substituted DNAs

Kalous, V., see J. Hudecek

Kamensky, Yu. A., see A.M. Arutjunjan

Kaminir, L.B., see G.A. Aphanasenko

Kamsteeg, J., J. van Brederode and G. van Nigtevecht, The formation of UDP-L-rhamnose from UDP-Dglucose by an enzyme preparation of Red Campion (Silene dioica (L.) Clairv)

Kaneko, H., see A. Yamada

Kanematsu, S. and K. Asada, Crystalline ferric superoxide dismutase from an anaerobic green sulfur bacterium, Chlorobium thiosulfatophilum

Kanner, B.I. and I. Sharon, Solubilization and reconstitution of the L-glutamic acid transporter from rat brain

98 (1979) 303

100 (1979) 141

100 (1979) 394

97 (1979) 196

97 (1979) 363

92 (1978) 53

100 (1979) 141

98 (1979) 161

94 (1978) 257

98 (1979) 161

98 (1979) 329

91 (1978) 202

98 (1979) 207

99 (1979) 180

100 (1979) 313

93 (1978) 185

99 (1979) 1

98 (1979) 13

92 (1978) 53

92 (1978) 357

96 (1978) 69

96 (1978) 41

96 (1978) 263

99 (1979) 265

100 (1979) 81

97 (1979) 61

92 (1978) 17

92 (1978) 85

96 (1978) 19

97 (1979) 193

96 (1978) 389

99 (1979) 199

99 (1979) 287

91 (1978) 173

95 (1978) 54

98 (1979) 299

98 (1979) 347

100 (1979) 374

95 (1978) 40

97 (1979) 77

91 (1978) 281

93 (1978) 16

91 (1978) 94

94 (1978) 245 
Kanner, B.I., see R. Maron

98 (1979) 237

Kanner, B.I., H. Fishkes, R. Maron, I. Sharon and S. Schuldiner, Reserpine as a competitive and reversible inhibitor of the catecholamine transporter of bovine chromaftin granules

Kapitza, E.L., E.A. Stukacheva and M.F. Shemyakin, Effect of Escherichia coli $\rho$ factor and RNase III on the formation of $\phi \mathrm{X} 174 \mathrm{RNA}$ in vitro

Karlsson, B., see K.-E. Falk

Karlsson, K.-A., I. Pascher, B.E. Samuelsson, J. Finne, T. Krusius and H. Rauvala, Mass spectrometric sequence study of the oligosaccharide of human transferrin

Karpeisky, M.Ya., see A.G. Pavlovsky

Kaschnitz, R., see J.H. Postlethwait

Katayama, K. and K. Titani, Cleavage of $\gamma$-carboxyglutamyl peptide bonds by cyanogen bromide and by $\mathrm{N}$-bromosuccinimide

Kather, H. and B. Simon, Adenylate cyclase of human fat cell ghosts: Effects of the vasoactive intestinal polypeptide (VIP) on the enzyme system of preadolescent and adult fat cells

Kato, K., Y. Umeda, F. Suzuki, D. Hayashi and A. Kosaka, Use of gelatin to remove interference by serum with the solid phase enzyme-linked sandwich immunoassay of insulin

Kato, T., see A. Yasutake

Katsumata, T., see S.-i. Ejiri

Katsumata, T., see K. Murakami

Katsumata, T., see S.-i. Ejiri

Katsumata, Y., O. Suzuki and M. Oya, Changes in the mean distance between tryptophan and fluorescense probe in the labeled sarcoplasmic reticulum membranes induced by detergents

Katz, A.M., see C.F. Louis

Kaufmann, K.J., see J.M. Fenton

Kawagishi, S., Y. Araki and E. Ito, A novel glycosidase, an endo-glucosaminidase active on the cell wall peptidoglycan with $N$-unsubstituted glucosamine residues

Kawamoto, S., M. Ueda, C. Nozaki, M. Yamamura, A. Tanaka and S. Fukui, Localization of carnitine acetyltransferase in peroxisomes and in mitochondria of $n$-alkane-grown Candida tropicalis

Kawamoto, S., T. Yamada, A. Tanaka and S. Fukui, Distinct subcellular localization of NAD-linked and FAD-linked glycerol-3-phosphate dehydrogenases in $\mathrm{N}$-alkane-grown $\mathrm{Candida}$ tropicalis

Kay, J.E., C.R. Benzie, P. Dicker and K. Lindahl-Kiessling, Inhibition of initiation of protein synthesis in rabbit reticulocyte lysates by a factor present in lymphocyte cytoplasm

Kay, J.E., see C.A. Phillips

Kaye, A.M., see M.D. Walker

Kaye, A.M., see M.D. Walker

Kazatchkov, Yu.A., see V.G. Budker

Kazazian, jr, H.H., see J.A. Phillips, iii

$\mathrm{Ke}$, B., see V.A. Shuvalov

Keil-Dlouha, V., see P. Herry

Kellogg, J, see Y. Oron

Kemmler, W., see H.U. Häring

Kenney, W.C., D.E. Edmondson, T.P. Singer, M. Nishikimi, E. Noguchi and K. Yagi, Identification of the covalently-bound flavin of $\mathrm{L}$-galactonolactone oxidase from yeast

Kenyon, W.H., R. Kringstad and C.C. Black, Diurnal changes in the malic acid content of vacuoles isolated from leaves of the Crassulacean acid metabolism plant, Sedum telephium

Keppler, D.O.R., see A. Holstege

Kerber, N.L., N.L. Pucheu and A.F. Garcia, PMS photo-inhibition in Rhodospirillum rubrum membranes in the presence of permeant entities affecting either the $\Delta \psi$ or the $\Delta \mathrm{pH}$ components of the protonmotive force

Kerckaert, J.-P., see B. Laine

Kerimov, T.M., see E.A. Imedidze

Kerr, M.A., see J.D. Londsdale-Eccles

Kervabon, A., J. Parello and J. Mery, Chemical studies in histone acetylation using a synthetic peptide fragment of histone $\mathrm{H} 4$

Keyhani, E., see J. Keyhani

Keyhani, J. and E. Keyhani, Mevalonic acid as a precursor of the alkyl sidechain of heme $a$ of cytochrome $c$ oxidase in yeast Saccharomyces cerevisiae

$100(1979) 175$

98 (1979) 123

98 (1979) 25

94 (1978) 413

92 (1978) 258

95 (1978) 247

95 (1978) 157

100 (1979) 145

99 (1979) 172

100 (1979) 241

92 (1978) 251

92 (1978) 255

95 (1978) 277

93 (1978) 58

93 (1978) 61

100 (1979) 1

97 (1979) 20

96 (1978) 37

97 (1979) 253

91 (1978) 40

94 (1978) 115

92 (1978) 25

98 (1979) 187

95 (1978) 143

97 (1979) 327

100 (1979) 5

95 (1978) 65

94 (1978) 331

95 (1978) 177

97 (1979) 40

94 (1978) 287

95 (1978) 361

94 (1978) 265

96 (1978) 291

96 (1978) 115

100 (1979) 157

98 (1979) 152

93 (1978) 271

93 (1978) 271 
Kharitonenkov, I.G., M.S. Siniakov, V.B. Grigoriev, I,M. Arefiev, A.P. Eskov and A.V Klimontovich, The length of the influenza virus spikes measured by photon correlation spectroscopy

Khechinashvili, N.N., see A.T. Gudkov

Khechinashvili, N.N., V.E. Koteliansky, Z.V. Gogia, J. Littlechild and J. Dijk, A heat denaturation study of several ribosomal proteins from Escherichia coli by scanning microcalorimetry

Khodyreva, S.N., see V.V. Vlassov

Khomutov, R.M., see A.I. Biryukov

Khomutov, R.M., see A.I. Biryukov

Kieda, C.M.T., D.J. Bowles, A. Ravid and N. Sharon, Lectins in lymphocyte membranes

Kieda, C.M.T., A.-C. Roche, F. Delmotte and M. Monsigny, Lymphocyte membrane lectins. Direct visualization by the use of fluoresceinyl-glycosylated cytochemical markers

Kikuchi, G., see M. Noguchi

Kindahl, H., see J.A. Lindgren

Kinglsey, P.B. and G.W. Feigenson, ${ }^{1}$ H NMR observation of small molecules in perdeuterated phosphatidylcholine vesicles

Kinnunen, P.K.J., see P. Somerharju

Kinnunen, P.K.J., see T. Kuusi

Kirk, K.L., see J.L. Costa

Kiselev, A.V., see Yu.A. Ovchinnikov

Kiss, $Z$, Inhibition of the glucagon stimulated adenylate cyclase activity by insulin

Kisselev, L.L., see G.K. Kovaleva

Kitagawa, S., F. Takaku and S. Sakamoto, Possible involvement of proteases in superoxide production by human polymorphonuclear leukocytes

Kitamura, K., A. Suzuki, M. Suzuki and K. Uyemura. Amino acid sequence of the glycopeptide derived from a major glycoprotein in bovine peripheral nerve myelin

Kleiner, D., Inhibition of the respiratory system in Azotobacter vinelandii

Kleinkauf, H., see M. Altmann

Klevanik, A.V., see V.A. Shuvalov

Klimontovich, A.V., see I.G. Kharitonenkov

Klinman, J., see A.R. Battersby

Klip, A., S. Grinstein and G. Semanza, Transmembrane disposition of the phlorizin binding protein of intestinal brush borders

Kloog, Y., D.M. Michaelson and M. Sokolovsky, Identification of muscarinic receptors in the Torpedo electric organ: evidence for their presynaptic localization

Kloog, Y., Y. Egozi and M. Sokolovsky, Regional heterogeneity of muscarinic receptors of mouse brain

Klotz, U., see T. Ferenci

Klyashchitskii, B.A., see L.N. Viktorova

Knaff, D.B., see J.D. Clemmer

Knaff, D.B., J.M. Olson and R.C. Price, The light reaction of the green photosynthetic bacterium Chlorobium f. thiosulfatophilum at cryogenic temperatures

Knaff, D.B., R. Whetstone and J.W. Carr, The role of the membrane potential in active transport by the photosynthetic bacterium Chromatium vinosum

Knappe, J, see H.P. Blaschkowski

Knippers, R., see A. Richter

Knoell, H.E., Ubiquinone synthesis in vitro starting from 2-octaprenyl phenol

Knott-Hunziker, V., S.G. Waley, B.S. Orlek and P.G. Sammes, Penicillinase active sites: Labelling of serine- 44 in $\beta$-lactamase $I$ by $6 \beta$-bromopenicillanic acid

Kobayashi, Y., S. Okahata, T. Sakano, K. Tanabe and T. Usui, Superoxide dismutase activity of T lymphocytes and non-T lymphocytes

Koch, S. and J. Niessing, Mode of inhibition of nuclear poly(A) polymerase by $2^{\prime}$-dATP and 3 '-dATP

Kodicek, M., Dependence of the spectral features of phenols on solvent: Spectrophotometric titration curve of tyrosine residue

Kohen, F., Z. Hollander, J.F. Burd and R.C. Boguslaski, A steroid immunoassay based on antibodyenhanced hydrolysis of a steroid-umbelliferone conjugate

Kohl, K.D., see W. Sperling

Koischwitz, H. see M. Altmann

Kolarov, J, see S. Kużela

96 (1978) 120

$93(1978) 215$

95 (1978) 270

$96(1978) \quad 95$

91 (1978) 246

91 (1978) 249

94 (1978) 391

99 (1979) 329

98 (1979) 281

98 (1979) 247

97 (1979) 175

96 (1978) 170

98 (1979) 314

$99(1979) 141$

100 (1979) 219

92 (1978) 29

95 (1978) 81

99 (1979) 275

$100(1979) \quad 67$

96 (1978) 364

93 (1978) 247

91 (1978) 135

96 (1978) 120

99 (1979) 297

99 (1979) 91

95 (1978) 331

97 (1979) 265

94 (1978) 213

91 (1978) 194

91 (1978) 346

98 (1979) 285

99 (1979) 283

98 (1979) 81

91 (1978) 293

97 (1979) 155

$99(1979) \quad 59$

98 (1979) 391

96 (1978) 354

$98(1979) 295$

$100(1979) 137$

97 (1979) 129

93 (1978) 247

91 (1978) 222 
Kolarov, J., S. Kużela, V. Krempaský, J. Lakota and V. Ujhảzy, ADP, ATP translocator protein of rat heart, liver and hepatome mitochondria exhibits immunological crossreactivity

96 (1978) 373

Kolb, H.J., see G. von Jagow

Koller, M.-E., Studies on the uptake of porphyrin by isolated rat liver mitochondria with particular emphasis on the effect of hemin

Kondo, M., see J. Simons

Konigsberg, W., see B. Frangione

Konishi, T. and L. Packer, The role of tyrosine in the proton pump of bacteriorhodopsin

Konopka, K., Differential effects of metal-binding agents on the uptake of iron from transferrin by isolated rat liver mitochondria

Konrad, M., see K. Akasaka

Konstantinov, A.A., see A.M. Arutjunjan

Kopitar, M., J. Brzin, T. Zvonar, P. Ločnikar, I. Kregar and V. Turk, Inhibition studies of an intracellular inhibitor on thiol proteinases

Kopperschläger, G., see P. Plietz

Korenstein, R., B. Hess and D. Kuschmitz, Branching reactions in the photocycle of bacteriorhodopsin

Korner, M., see M. Laburthe

Korsuize, J., see A. de Waard

Kosaka, A., see K. Kato

Koteliansky, V.E., see N.N. Khechinashvili

Koteliansky, V.E., see V.D. Vasiliev

Kovaleva, G.K., S.G. Moroz, O.O. Favorova and L.L. Kisselev, Tryptophanyl-tRNA synthetase: evidence

for an anhydrous bond involved in the tryptophanyl enzyme formation

Koyama, J., see K. Nagai

Koyasu, S., see A. Fukuda

Kozdrowski, I., see E.G. Berger

Kozlov, 1.A., see I.E. Drobinskaya

Kozlov, I.A., see E.A. Imedidze

Kraayenhof, R., see J.J. Schuurmans

Krab, K., see M. Wikström

Krajcarski, D.T., see A.G. Szabo

Kranias, E., see G. Kranias

Kranias, G., E. Kranias, G.J. Dobbie, B.K. Edwards, U. Eppenberger and R.A. Jungmann, Human platelet protein kinases in diabetic retinopathy

Krebs, E.G., see T.-S. Huang

Kregar, I, see M. Kopitar

Krempaský, V., see S. Kuzela

Krempaský, V., see J. Kolarov

Krenning, E.P., R. Docter, H.F. Bernard, T.J. Visser and G. Hennemann, Active transport of triiodothyronine $\left(\mathrm{T}_{3}\right)$ into isolated rat liver cells

Kreuzaler, F., RJ. Light and K. Hahlbrock, Flavanone synthase catalyzes $\mathrm{CO}_{2}$ exchange and decarboxylation of malonyl-CoA

Krieg, L., see C. Flytzanis

Kringstad, R., see W.H. Kenyon

Krishnamoorthy, R., A.B. Bosisio, D. Labie and P.G. Righetti, Titration curves of liganded hemoglobins by combined isoelectric focusing - electrophoresis

Krishnan, K.S., J.F. Brandts and S.S. Lehrer, Effects on an interchain disulfide bond on tropomyosin structure: differential scanning calorimetry

Krishnan, M. and A. Gnanam, A basic chlorophyll - protein complex

Krog, H.H., see T.C. Bøg-Hansen

Krukov, P.G., see V.A. Shuvalov

Krümpelmann, D., see W. Ribbing

Krusius, T., see K.-A. Karlsson

Kubo, S., see S. Hidaka

Kubota, S., see H. Terada

Kühl, P.W. The receptor of bacteriophage $\lambda$ : evidence for its dimeric nature

Kühlbrandt, W. and R.A. Garrett, A ribonucleoprotein core in the $50 \mathrm{~S}$ ribosomal subunit of Escherichia coli

$91(1978) 121$

$100(1979) \quad 47$

91 (1978) 53

96 (1978) 381

92 (1978) 1

92 (1978) 308

96 (1978) 287

95 (1978) 40

91 (1978) 355

91 (1978) 230

93 (1978) 266

98 (1979) 41

96 (1978) 106

99 (1979) 172

95 (1978) 270

95 (1978) 273

95 (1978) 81

92 (1978) 299

95 (1978) 70

93 (1978) 105

96 (1978) 111

96 (1978) 115

94 (1978) 405

91 (1978) 8

94 (1978) 249

92 (1978) 357

92 (1978) 357

$98(1979) \quad 66$

91 (1978) 355

91 (1978) 222

96 (1978) 373

91 (1978) 113

94 (1978) 175

96 (1978) 201

94 (1978) 281

$94(1978) 319$

91 (1978) 206

97 (1979) 322

93 (1978) 86

91 (1978) 135

92 (1978) 105

94 (1978) 413

98 (1979) 115

$100(1979) \quad 37$

96 (1978) 385

94 (1978) 207 
Kuiper, H.A., A. Finazzi Agrò, E. Antonini and M. Brunori, The replacement of calcium by terbium as an allosteric effector of hemocyanins

99 (1979) 317

Kulkoski, J.A., B.L. Peterson, B. Elcombe, J.L. Winkelhake and J.G. Ghazarian, Ferredoxin of

25 -hydroxyvitamin $D_{3}-1 \alpha$-hydroxylase. Anatomical distribution in the chick as determined by double-antibody radioimmunoassay

Kumakura, K., F. Battaini, M. Hofmann, P.F. Spano and M. Trabucchi, Inhibitory effects of cyclic-AMP dependent protein kinase on guanylate cyclase activity in rat cerebellum

Kunau, W.H. and F. Lauterbach, Inhibition of linoleic acid degradation by hypoglycin A

Kunze, D., see B. Rüstow

Kuroda, K., see T. Maeda

Kurosu, H., see K. Fujii

Kurtskhalia, T.V., see A.S. Girshovich

Kuschmitz, D., see R. Korenstein

Kuschmitz, D., see B. Hess

Kusunose, E., see S. Toriyama

Kusunose, M., see S. Toriyama

Kuthan, H., H. Tsuji, H. Graf, V. Ullrich, J. Werringloer and R.W. Estabrook, Generation of superoxide anion as a source of hydrogen peroxide in a reconstituted monooxygenase system

Kuusi, T., see P. Somerharju

Kuusi, T., P.K.J. Kinnunen, C. Ehnholm and E.A. Nikkilä, A simple purification procedure for rat hepatic lipase

Kužela, Š., J. Kolarov, V. Krempaský, J. Lakota and V. Ujházy, Mitochondrial ATPase of Zajdela

hepatoma. Presence of $F_{1}$-specific antigenic determinants outside mitochondria

Kužela, Š., see J. Kolarov

Kuznetsov, S.A., V.I. Rodinov, V.I. Gelfand and V.A. Rosenblat, Purification of a thermostable high molecular weight factor promoting tubulin polymerization

Kuznetsov, S.A., V.I. Gelfand, V.I. Rodionov, V.A. Rosenblat and J.G. Gulyaeva, Polymerization of purified tubulin by synthetic polycations

Kuznetsova, E.D., see K.G. Gasaryan

Labie, D., see R. Krishnamoorthy

Laburthe, M., G. Rosselin, M. Rousset, A. Zweibaum, M. Korner, Z. Selinger and M. Schramm, Transfer of the hormone receptor for vaso-intestinal peptide to an adenylate cyclase system in another cell.

Laduron, P., see H. Gorissen

Laduron, $\mathbf{P}_{\text {.y }}$ see H. Gorissen

Lagerkvist, U., see P. Elias

Lai, C.Y., F. Cancedda and D. Chang, Primary structure of cholera toxin subunit $A_{1}$ : Isolation, partial sequences and alignment of the $\mathrm{BrCN}$ fragments

Laine, B., J.-P. Kerckaert, P. Sautiere and G. Biserte, Preparation of the DNA-binding protein HU from Escherchia coli by immuno-affinity chromatography

Lakota, J., see S. Kužla

Lakota, J., see J. Kolarov

Lakshrnanan, J., Nerve growth factor induced phosphatidylinositol turnover. Effect of 6-hydroxydopamine treatment

Lakshmanan, J., Involvement of post-synaptic cytoskeleton in nerve growth factor-induced 'PI-effect'

Laland, S.G., see M. Gacek

Lamb, C.J. and R.A. Dixon, Stimulation of de novo synthesis of L-phenylalanine ammonia-lyase during induction of phytoalexin biosynthesis in cell suspension cultures of Phaseolus vulgaris

Lamb, J.F., see J. Singh

Lambert, M., M. Svoboda and J. Christophe, Hormone-stimulated GTPase activity in rat pancreatic plasma membranes

Lamy, F, see M. Davril

Landriscina, C., see G.V. Gnoni

Lang, M., see S. Huprikar

Langley, J., see K.D. Hepp

Lappert, M.F., see O.C. Wallis

Lamer, I, see Y. Oron

99 (1979) 183

93 (1978) 231

94 (1978) 120

95 (1978) 225

98 (1979) 157

97 (1979) 193

92 (1978) 203

93 (1978) 266

100 (1979) 334

95 (1978) 111

95 (1978) 111

91 (1978) 343

96 (1978) 170

98 (1979) 314

91 (1978) 222

96 (1978) 373

95 (1978) 339

95 (1978) 343

94 (1978) 136

94 (1978) 319

98 (1979) 41

96 (1978) 64

100 (1979) 281

98 (1979) 145

$100(1979) \quad 85$

96 (1978) 291

91 (1978) 222

96 (1978) 373

92 (1978) 159

95 (1978) 161

98 (1979) 355

94 (1978) 277

91 (1978) 269

99 (1979) 303

98 (1979) 128

94 (1978) 179

99 (1979) 167

91 (1978) 325

97 (1979) 196

94 (1978) 331 


\section{FEBS LETTERS}

Larriba, G., O-Glycosidically linked fucose in high molecular weight glycoproteins, in normal and virus-transformed rat cells

Larsson, P.-O., see S. Ohlson

Larsson, P.O., see M.-O. Mănsson

Larsson, P.-O. and K. Mosbach, Affinity precipitation of enzymes

Lashkevich, V.A., see Yu.V. Svitkin

Lauber, M., M. Camier and P. Cohen, Immunological and biochemical characterization of distinct high molecular weight forms of neurophysin and somatostatin in mouse hypothalamus extracts

Laughrea, M., J. Dondon and M. Grunberg-Manago, The relationship between the 3' end of 16 S RNA and the binding of initiation factor IF-3 to the 30 S subunit of Escherichia coli

Launder, J.M., see Q.F. Ahkong

Lauquin, G.J.M., see F. Boulay

Laursen, R.A. and L. Duffy, The evolution of elongation factors Tu and $\mathrm{G}$ by gene duplication

Lauterbach, F., see W.H. Kunau

Lauterwein, J. and K. Wüthrich, A possible structural basis for the different modes of action of neurotoxins and cardiotoxins from snake venom

Law, R.E., R.M. Sinibaldi, A.J. Ferro and M.R. Cummings, Effect of 5'-methylthioadenosine on gene action during heat shock in Drosophila melanogaster

Law, S., see P. Guy

Lawford, H.G., see J.C. Cox

Lazdunski, M., see T.B. Rogers

Lazo, P.A. and A. Sols, Specific inactivation of animal hexokinases by xylose in vitro, in situ and in vivo

Lea, P.J., W.R. Mills and B.J. Miflin, The isolation of a lysine-sensitive aspartate kinase from pea leaves and its involvement in homoserine biosynthesis in isolated chloroplasts

Leadlay, P.F., Free $(S, S)$-diaminopimelate is not an obligatory intermediate in lysine biosynthesis in Corynebacterium glutamicum

Lee, A.G., J. Rogers, D.C. Wilton, K.P. Ghiggino and D. Phillips, Spectroscopic resolution of drug binding sites in biological membranes

Lee, C.-Y., see B. Pegoraro

Lee, L., B.D. Sykes and E.R. Bimbaum, A determination of the relative compactness of the $\mathrm{Ca}^{2+}$-binding sites of the $\mathrm{Ca}^{2+}$-binding fragment of troponin-C and parvalbumin using lanthanide-induced ${ }^{1} \mathrm{H}$ NMR shifts

Leenstra, W.R., see R.H. Clarke

Leer, J.C., see C. Tsopanakis

Lefebvre, G., N. Martin and R. Gay, Periodic cyclic AMP uptake by synchronously grown cells of Nocardia restricta and Arthrobacter globiformis

Le Gaillard, F. and M. Dautrevaux, The accessible cysteine residue of human transcortin. Evidence for oxidation of the sulphydryl group

Leger, D., V. Tordera, G. Spik, L. Dorland, J. Haverkamp, and J.F.G. Vliegenthart, Structure determination of the single glycan of rabbit serotransferrin by methylation analysis and $360 \mathrm{MHz}{ }^{1} \mathrm{H}$ NMR spectroscopy

Legoy, M.-D., J.-M. le Moullec and D. Thomas, Chemical grafting of functional NAD in the active site of a dehydrogenase - regeneration in situ

Lehmann, H., see G. Nozari

Lehmann, H., see O. Castillo

Lehmann, H., see M.C. Botha

Lehnert, T., see H.H. Berlet

Lehrer, S.S., see K.S. Krishnan

Lehtonen, M.A., M.J. Savolainen and I.E. Hassinen, Hormonal regulation of hepatic soluble phosphatidate phosphohydrolase. Induction by cortisol in vivo and in isolated perfused rat liver

Leick, V., see P.E. Nielsen

Leigh, J.S., see P.R. Rich

Leloir, L.F., see R.A. Ugalde

Lemley, S. and O.P. Chilson, Antigenic structure of AMP-deaminase: isozyme specificity of antibodies directed against purified erythrocyte enzyme

Le Moullec, J.-M., see M.-D. Legoy

Leng, M., E. Sage, R.P.P. Fuchs and M.P. Daune, Antibodies to DNA modified by the carcinogen $N$-acetoxy- $N$-2-acetyl-aminofluorene

95 (1978) 190

93 (1978) 5

98 (1979) 309

98 (1979) 333

96 (1978) 211

97 (1979) 343

91 (1978) 265

95 (1978) 147

98 (1979) 161

92 (1978) 200

94 (1978) 120

93 (1978) 181

99 (1979) 247

94 (1978) 33

93 (1978) 261

98 (1979) 373

98 (1979) 88

98 (1979) 165

98 (1979) 399

94 (1978) 171

95 (1978) 371

98 (1979) 169

99 (1979) 207

93 (1978) 297

$93(1978) \quad 55$

94 (1978) 63

93 (1978) 255

94 (1978) 335

95 (1978) 88

96 (1978) 12

96 (1978) 331

91 (1978) 45

91 (1978) 206

99 (1979) 162

94 (1978) 287

93 (1978) 323

91 (1978) 209

94 (1978) 51

94 (1978) 335

92 (1978) 207 
Leone, A., A.J. Shatkin and R. Cancedda, Isolation of Sindbis virus 26 S RNA by cDNA-cellulose chromatography

Leoni, S., S. Spagnuolo and A. Panzali, Rat liver adenylate cyclase and phosphodiesterase dependence on $\mathrm{Ca}^{2+}$ and on cytoplasmic factors during liver regeneration

Lepreau-Jose, M.J., see M.J.H. Geelen

Lemer, E.I, see D. Cahen

Leschinskaya, I.B., see G.A. Aphanasenko

Leseney, A.-M., J.-J. Befort, N. Befort, M. Benmiloud and N. Defer, Effects of thyroidectomy on glucocorticoid receptors in rat liver

Levin, S., see D. Gurari-Rotman

Levin, Y. and B.-A. Sela, Studies on amino acid and peptide derivatives of daunorubicine

Lewis, J.G. and C.M. André, A serum DNA-binding protein absent in malignant disease

Lewis, W.G., see G. Côté

Lewis, W.G., see G.P. Côté

Lewis, W., see L.-A. Fransson

Lichtenberg, D., see Y. Barenholz

Lien, E., see D. Sarantakis

Lien, S. and A. San Pietro, On the reactivity of oxygen with photosystem I electron acceptors

Ligeti, E., see A. Fonyó

Ligeti, E, see A. Fonyó

Light, N.D. and A.J. Bailey, Changes in crosslinking during aging in bovine tendon collagen

Light, N.D., see A.J. Bailey

Light, R.J., see F. Kreuzaler

Liljas, A., see L. Pettersson

Lindahl-Kiessling, K., see J.E. Kay

Lindgren, J.Å, H.-E. Claesson, H. Kindahl and S. Hammarström, Effects of adenosine 3':5'-monophosphate and platelet aggregation on thromboxane biosynthesis in human platelets

Lindman, B., see T. Drakenberg

Lindman, B., see A. Cave

Lindman, B., see J. Parello

Lindner, H.J., see W. Hillen

Lindstedt, G., see G. Cederblad

Lindstedt, S., see G. Cederblad

Lingrel, J.B., see V.R. Haynes

Linke, L., see A. Wahlländer

Lintner, $\mathbf{K}$, see J. Vičar

Littauer, U.Z., see I. Gozes

Littlechild, J., see R. Österberg

Littlechild, J., see N,N. Khechinashvili

Litwin, S., see M. Wong

Ljones, T., T. Flatmark, T. Skotland, L. Petersson, D. Bäckström and A. Ehrenberg, Dopamine $\beta$-monooxygenase: electron paramagnetic resonance and oxidation - reduction properties of the enzyme-bound copper

Ljones, T., Nitrogen fixation and bioenergetics: the role of ATP in nitrogenase catalysis

Llama, M.J., J.L. Serra, K.K. Rao and D.O. Hall, Isolation and characterization of the hydrogenase activity from the non-heterocystous cyanobacterium Spirulina maxima

Lobanov, N.A., see Yu.A. Ovchinnikov

Loc̆nikar, P., see M. Kopitar

Loeb, J.E., see R. Counis

Loh, Y.P. and H. Gainer, The role of glycosylation on the biosynthesis, degradation, and secretion of the ACTH- $\beta$-lipoprotein common precursor and its peptide products

London, E. and G.W. Feigenson, Fluorescence quenching of $\mathrm{Ca}^{2+}-\mathrm{ATPase}$ in bilayer vesicles, by a spin-labeled phospholipid

Londsdale-Eccles, J.D., M.A. Kerr, K.A. Walsh and H. Neurath, Catalysis by zymogens: Increased reactivity at high ionic strength

Lorimer, G.H., see H.W. Heldt

Loskutoff, D.J., Preparation of tissue culture serum lacking $\alpha_{2}$-macroglobulin

$100(1979) 103$

92 (1978) 63

95 (1978) 326

91 (1978) 339

97 (1979) 77

99 (1979) 239

94 (1978) 187

98 (1979) 119

92 (1978) 211

91 (1978) 237

94 (1978) 131

97 (1979) 119

99 (1979) 210

92 (1978) 153

99 (1979) 189

93 (1978) 289

96 (1978) 343

97 (1979) 183

99 (1979) 361

94 (1978) 175

98 (1979) 139

91 (1978) 40

98 (1979) 247

92 (1978) 346

$100(1979) 148$

100 (1979) 153

94 (1978) 361

98 (1979) 57

98 (1979) 57

91 (1978) 173

97 (1979) 138

97 (1979) 275

99 (1979) 86

93 (1978) 115

95 (1978) 270

95 (1978) 26

92 (1978) 81

98 (1979) 1

98 (1979) 342

100 (1979) 219

91 (1978) 355

96 (1978) 69

$96(1978) 269$

96 (1978) 51

100 (1979) 157

92 (1978) 234

94 (1978) 73 


\section{FEBS LETTERS}

Lötscher, H.R., K. Schwerzmann and E. Carafoli, The transport of $\mathrm{Ca}^{2+}$ in a purified population of inside-out vesicles from rat liver mitochondria

Louis, C.F., G. Fudyma, P. Nash-Adler, M. Shigekawa and A.M. Katz, Effects of monovalent cation ionophores on calcium uptake by rabbit skeletal muscle sarcoplasmic reticulum vesicles

Louis, Ch., see A. Alonso

Louis, C., see C. Flytzanis

Löw, H., F.L. Crane, C. Grebing, M. Tally and K. Hall, Hormone control of plasma membrane oxidation reduction reactions: effects of insulin

Lowe, D.J., see R.R. Eady

Loyter, A., see D.J. Volsky

Luchinat, C., see I. Bertini

Lucy, J.A., see B. Maggio

Lucy, J.A., see Q.F. Ahkong

Lucy, J.A., see A.M.J. Blow

Ludwig, P., M. Bartels, T. Schewe and S. Rapoport, Selective inactivation of the NADH-ubiquinone segment of the respiratory chain of submitochondrial particles by endogenous free fatty acids during hyperthermia

Lugtenberg, B., R. van Boxtel, C. Verhoef and W. van Alphen, Pore protein e of the outer membrane of Escherichia coli $\mathrm{K} 12$

Lund, T, see K. Poulsen

Lundblad, A., S. Svensson, I. Yamashina and M. Ohta, Increased urinary excretion of a glucose-containing tetrasaccharide in patients with duchenne muscular dystrophy

Lussan, C., see F. Hare

Lustig, F., see P. Elias

Lyapustin, V.N., see Yu.V. Svitkin

Lykkegaard, S., see K. Poulsen

Lyles, J.M., see I. Silman

Lynn, K.R., see A.G. Szabo

Maat, J., see A. de Waard

Machleidt, I., see G. von Jagow

Machleidt, W.,see G. von Jagow

Macnaughton, M.R., The genomes of three coronaviruses

MacNeal, R.K., see D.L. Purich

Maeda, A., T. Ogurusu, Y. Shichida, F. Tokunaga and T. Yoshizawa, Formations of a 7-cis retinal pigment by irradiating cattle rhodopsin at low temperatures

Maeda, T., K. Kuroda, S.-i. Ohnishi, D.J. Anstee and M.J.A. Tanner, Interaction between haemagglutinating virus of Japan and human En(a-) erythrocytes lacking major sialoglycoprotein

Maget-Dana, R., see A.-C. Roche

Maggio, B. and J.A. Lucy, Interactions of water-soluble fusogens with phospholipids in monolayers

Maghuin-Rogister, G. and G. Hennen, Effect of guanyl nucleotides on follitropin-dependent adenylate cyclase in the testis

Magnusson, C.G.M., see C.F.A. Bryce

Maguire, J.J., see R. Cammack

Maia, J.C.C., see S.L. Gomes

Mainka, L., see G. Zimmer

Malagrida, L., see R. Pecquery

Maldonado, J.M., B.A. Notton and E.J. Hewitt, Effects of reduced dehydrogenase electron acceptors on the various nitrate dependent activities of spinach (Spinacea oleracea L.) nitrate reductase

Malinowski, D., see J.D. Stoesz

Malkin, S., see D. Cahen

Malmström, B.G., see J.C. Cox

Malygin, A.G., see M.F. Shemyakin

Mandel, P., see J.E. Hesketh

Mandel, P., see M. Recasens

Mandel, P., see C. Froissart

Mangiarotti, G., see A. Ceccarelli

99 (1979) 194

93 (1978) 61

93 (1978) 351

96 (1978) 201

91 (1978) 166

95 (1978) 211

92 (1978) 190

93 (1978) 251

94 (1978) 301

95 (1978) 147

94 (1978) 305

95 (1978) 181

96 (1978) 99

98 (1979) 135

97 (1979) 249

94 (1978) 231

98 (1979) 145

96 (1978) 211

98 (1979) 135

94 (1978) 166

94 (1978) 249

96 (1978) 106

91 (1978) 121

91 (1978) 121

94 (1978) 191

96 (1978) 83

92 (1978) 77

98 (1979) 157

93 (1978) 91

94 (1978) 301

100 (1979) 121

96 (1978) 257

93 (1978) 278

99 (1979) 39

94 (1978) 223

98 (1979) 241

93 (1978) 169

91 (1978) 320

91 (1978) 339

93 (1978) 157

91 (1978) 253

94 (1978) 357

99 (1979) 51

100 (1979) 276

93 (1978) 348 
Mani, J.-C., see J.-C. Bonnafous

99 (1979) 152

Manley, S.L. and D.J. Chapman, Formation of 3-bromo-4-hydroxybenzaldehyde from L-tyrosine in cell-free homogenates of Odonthalia floccosa (rhodophyceae): a proposed biosynthetic pathway for brominated phenols

Mann, K., M. Giesel, H. Fasold and W. Haase, Isolation of native microtubules from porcine brain and characterization of SH groups essential for polymerization at the GTP binding sites

Mannervik, B., Generalized definition of inhibition pattern for non-Michaelian enzyme steady-state kinetics

Mannervik, B., see I. Carlberg

Mannherz, H.G. and G. Rohr, 5'-Nucleotidase reverses the inhibitory action of actin on pancreatic deoxyribonuclease I

Mannherz, H.G., see G. Rohr

Mansour, T.E., see D.L. Smith

Mansson, M.-O., P.-O. Larsson and K. Mosbach, Recycling by a second enzyme of NAD covalently bound to alcohol dehydrogenase

Mäntsälä, P., see A. Möttönen

Mapleston, R.E. and W.T. Griffiths, Effects of illumination of etiolated leaves on the redox state of NADP in the plastids

Marathe, G.V., see E.M. Grau

Marchesini, A., see L. Avigliano

Margolis, L.B., see R.M. Hoffman

Margotat, A., P.-H. Rolland, B. Charrier and J. Mauchamp, Depressive effect of thyrotropin in the physiological dose range on prostaglanding $\mathrm{E}_{2}$ synthesis and accumulation in cultured hog thyroid cells

Marinari, U.M., see G. Nanni

Markova, L.F., see T.A. Muranova

Marks, V., see M.J. O'Sullivan

Markwell, J.P., C.D. Miles, R.T. Boggs and J.P. Thornber, Solubilization of chloroplast membranes by zwitterionic detergents: Effect on photosystem II activity

Marmocchi, F., G. Venardi, F. Bossa, A. Rigo and G. Rotilio, Dissociation of Cu - Zn superoxide dismutase into monomers by urea. Evidence from gel filtration and molecular hybridization

Maro, B. and M. Bornens, The effect of zinc chloride on the redistribution of surface immunoglobulins in rat $B$ lymphocytes

Maron, R., B.I. Kanner and S. Schuldiner, The role of a transmembrane pH gradient in 5-hydroxy tryptamine uptake by synaptic vesicles from rat brain

Maron, R., see B.I. Kanner

Marsho, T.V., see P.M. Sokolove

Marston, S., Complex kinetics of actin-subfragment-1 ATPase at low temperature

Martin, H.H., see K. Nixdorff

Martin, N., see G. Lefebvre

Martinez-Pardo, M., P.G. Montes, M. Martin-Lomas and A. Sols, Intestinal lactase evaluation in vivo with 3-methyllactose

Martin-Lomas, M., see M. Martinez-Pardo

Martinotti, G., see P. Cappuccinelli

Martonosi, A., see T. Beeler

Mašek, F., see M. Sedliaková

Mason, A.N., see M.E. Tenneson

Massa, E.M., see E.M. de Melián

Massagué, J., see C.J. Ciudad

Massarelli, R., see C. Froissart

Massoulie, J., see S. Carson

Masui, M., see S. Toriyama

Mateeva, Z.E. and A.A. Hadjiolov, Unprotected 5 -segments of poly(A) ${ }^{+}-$mRNA in Saccharomyces cerevisiae polysomes

Matheson, A.T., see G.E. Willick

Matsubara, H., see T. Hase

Matsubara, H., see T. Hase

Matsumoto, M., see Y. Suzuki

Matsumoto, M., see Y. Hirabayashi

93 (1978) 97

92 (1978) 45

93 (1978) 225

98 (1979) 263

95 (1978) 284

99 (1979) 35I

92 (1978) 57

98 (1979) 309

91 (1978) 365

92 (1978) 168

98 (1979) 91

100 (1979) 318

93 (1978) 365

95 (1978) 347

93 (1978) 242

96 (1978) 301

95 (1978) 311

99 (1979) 11

94 (1978) 109

97 (1979) 116

98 (1979) 237

100 (1979) 175

100 (1979) 179

92 (1978) 151

94 (1978) 298

93 (1978) 55

98 (1979) 99

98 (1979) 99

91 (1978) 153

98 (1979) 173

92 (1978) 133

91 (1978) 140

92 (1978) 143

99 (1979) 321

100 (1979) 276

97 (1979) 348

95 (1978) 111

94 (1978) 342

92 (1978) 187

91 (1978) 315

96 (1978) 41

92 (1978) 173

100 (1979) 253 
Matsuzaki, S., see K. Hamana

99 (1979) 325

Matthews, H.R., see K. Mitchelson

Matveetz, Ju. A., see V.A. Shuvalov

Mauchamp, J., see A. Margotat

Mauco, G., H. Chap and L. Douste-Blazy, Characterization and properties of a phosphatidylinositol phosphodiesterase (phospholipase $\mathrm{C}$ ) from platelet cytosol

Maurizot, J.-C., see A.-C. Roche

Mayer, L., see G. Dietze

Mayer, L., see M. Wicklmayr

Mazabraud, A., Deficiency of the peroxy-Y base in oocyte phenylalanine tRNA

Mazur, Y., see M. Sheves

Mazur, Y., see S. Edelstein

McArthur, H.A.I., see F.M. Roberts

McCarty, R.E., AMP is converted to ADP and ATP in the medium before it is bound to coupling factor 1 in illuminated spinach chloroplast thylakoids

McClelland, C.E., see A.E.G. Cass

McFadden, B.A., see A.K. Soluja

McFarland, J.T., see J. Schmidt

McKee, J.W.A. and J.C. Hawke, The incorporation of $\left[{ }^{14} \mathrm{C}\right]$ bicarbonate and ${ }^{14} \mathrm{CO}_{2}$ into the constituent fatty acids of monogalactosyldiacylglycerol by spinach chroroplasts and leaves

McKinley-McKee, J.S., see K.H. Dahl

McKinley-McKee, J.S., see K.H. Dahl

McNamee, M.G., see Weidoff, P.M., jr

McNeil, P.H., see S.P. Robinson

Mecke, D., see S. Hartmann

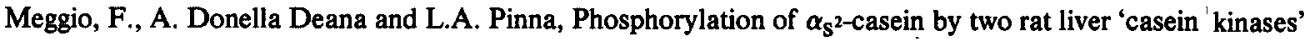

Mehlhorn, R.J., see A.T. Quintanilha

Meissner, H.P., J.C. Henquin and M. Preissler, Potassium dependence of the membrane potential of pancreatic B-cells

Melandri, B.A., A. De Santis, G. Venturoli and A. Baccarini Melandri, The rates of onset of photophosphorylation difference in bacterial chromatophores

Melandri, B.A., see S. de Chadarevjan

Melis, A., Oxidation - reduction potential dependence of the two kinetic components in chloroplast system II primary photochemistry

Mende, L., The primary structure of protein L13 from the large subunit of Escherichia coli ribosomes

Mende, L., B. Timm and A.R. Subramanian, Primary structures of two homologous ribosome-associated DNA-binding proteins of Escherichia coli

Mendel-Hartvig, I. and B.D. Nelson, Labeling of complex III peptides in beef heart mitochondria and submitochondrial particles by diazonium benzene $\left[{ }^{35} \mathrm{~S}\right]$ sulfonate

Menestrina, G., see R. Antolini

Mennucci, L., see S.L. Gomes

Mentlein, R., see E. Heymann

Merlevede, W., see J. Goris

Mery, J., see A. Kervabon

Meshulam, T., see A.W. Segal

Mestechkina, N.M., see B.Yu. Zaslavsky

Mian, N., see A.J. Pope

Miassod, R. and J.P. Cecchini, Hormone effect on the half-life of the 42 S pre-rRNA of cultured sycamore cells

Michaelson, D.M., see Y. Kloog

Michel, G., see C. Garbay-Jaureguiberry

Michel, G., The changes in cell size and phospholipid composition during growth of a chain-forming envC mutant of Escherichia coli

Michel-Beyerle, M.E., H. Scheer, H. Seidlitz, D. Tempus and R. Haberkorn, Time-resolved magnetic field effect on triplet formation in photosynthetic reaction centers of Rhodopseudomonas sphaeroides, R-26

Michelson, A.M., see M. Wauters

Middelhoff, G.W., see W.F. Riesen

92 (1978) 339

91 (1978) 135

95 (1978) 347

100 (1979) 367

91 (1978) 233

92 (1978) 294

98 (1979) 61

100 (1979) 235

96 (1978) 75

97 (1979) 241

97 (1979) 211

95 (1978) 299

94 (1978) 311

96 (1978) 361

96 (1978) 263

94 (1978) 273

99 (1979) 308

99 (1979) 313

100 (1979) 389

97 (1979) 296

93 (1978) 339

91 (1978) 216

91 (1978) 104

94 (1978) 87

95 (1978) 130

97 (1979) 293

95 (1978) 202

96 (1978) 313

96 (1978) 395

92 (1978) 36

100 (1979) 377

99 (1979) 39

91 (1978) 360

99 (1979) 279

98 (1979) 152

100 (1979) 27

94 (1978) 77

93 (1978) 174

96 (1978) 273

95 (1978) 331

93 (1978) 151

100 (1979) 258

100 (1979) 9

91 (1978) 276

91 (1978) 35 
Miflin, B.J., see P.J. Lea

98 (1979) 165

Miheeva, L.M., see B.Yu. Zaslavsky

94 (1978) 77

Mikoshiba, K., see O.S. Jørgensen

93 (1978) 185

Miles, C.D., see J.P. Markwell

Milgröm, E., see A.M. Arutjunjan

99 (1979) 11

95 (1978) 40

Mills, J.D., see D. Crowther

Mills, W.R. and K.G. Wilson, Amino acid biosynthesis in isolated pea chloroplasts: metabolism of labeled aspartate and sulfate

Mills, W.R., see P.J. Lea

Miravet, L., see J. Redel

Mirelman, D., see A. Zaritsky

Mishal, Z., see M. Castagna

Mitchelson, K., T. Chambers, E.M. Bradbury and H.R. Matthews, Activation of histone kinase in G2 phase of the cell cycle in Physarum polycephalum

Mitra, S.K., Yeast tRNA Lys (anticodon CUU) translates AAA codon

Mitzner, B.I., see Yu.A. Ovchinnikov

Miura, K.-I., see S. Hidaka

Miyachi, S., see Y. Shiraiwa

Miyata, E., see Y. Sato

Miyatake, T., T. Yamada, M. Suzuki, B. Pallmann, K. Sandhoff, T. Ariga and T. Atsumi, Sialidase deficiency in adult-type neuronal storage disease

Miyazaki, K., see A. Yasutake

Mizuno, D., see Y. Nakanishi

Mizuno, D., see Y. Nagamine

Mizushima, S., see F. Yu

Mohr, P., see R. Renneberg

Molinier-Jumel, C., see M. Capri

Möller, W., see K. Roobol

Mondovi, B., see M.T. Costa

Mondovi, B., see A. Desideri

Mondovi, B., see L. Avigliano

Monet, J.-D., C.A. Bader, E. d'Herbigny and J.-L. Funck-Brentano, In vitro relative biological activities of (1-34) N-terminal synthetic fragments of human parathyroid hormone in the human renal cortical adenylate cyclase assay

Mongongu, S., see R. Counis

Monsigny, M., see A.-C. Maurizot

Monsigny, M., see A.-C. Roche

Monsigny, M., see C. Kieda

Montes, P.G., see M. Martinez-Pardo

Moo-Penn, W.F., J.A. Wolff, G. Simon, M. Vacek, D.L. Jue and M.H. Johnson, Hemoglobin presbyterian: $\beta 108$ (G10) asparagine $\rightarrow$ lysine. A hemoglobin variant with low oxygen affinity

Moore, A.L. and H. Rupp, The interaction of ubisemiquinones with the iron - sulphur centre S-3 of succinate dehydrogenase in plant mitochondria

Moore, T.A., see M.E. Edgerton

Mordasini, R.C., see W.F. Riesen

Morero, R.D., see E.M. de Melián

Morgan, J.L., C.R. Holladay and B.S. Spooner, Tubulin antibody inhibits in vitro polymerization independently of microtubule-associated proteins

Morinaga, T., G. Funatsu, M. Funatsu, B. Wittman-Liebold and H.G. Wittman, Primary structure of protein L14 isolated from Escherichia coli ribosomes

Morita, K., see E. Tachikawa

Morkin, E., see I.L. Flink

Moroz, S.G., see G.K. Kovaleva

Morpurgo, L., see A. Desideri

Morris, D., see M.J. O'Sullivan

Morris, J.G., see D.J. Clarke

Mosbach, K., see S. Ohlson

92 (1978) 129

98 (1979) 165

96 (1978) 216

98 (1979) 29

$100(1979) \quad 62$

92 (1978) 339

91 (1978) 78

97 (1979) 15

98 (1979) 115

95 (1978) 207

98 (1979) 271

97 (1979) 257

100 (1979) 241

93 (1978) 357

99 (1979) 29

100 (1979) 71

96 (1978) 349

91 (1978) 329

96 (1978) 377

94 (1978) 112

98 (1979) 339

100 (1979) 318

96 (1978) 79

96 (1978) 69

91 (1978) 233

93 (1978) 91

99 (1979) 329

98 (1979) 99

92 (1978) 53

93 (1978) 73

95 (1978) 35

91 (1978) 35

92 (1978) 143

93 (1978) 141

91 (1978) 74

100 (1979) 331

94 (1978) 125

95 (1978) 81

98 (1979) 339

95 (1978) 311

100 (1979) 52

93 (1978) 5 
Mosbach, K., see M.-O. Mânsson

Mosbach, K., see P.-O. Larsson

Motosugi, K., see T. Yagi

Mouttet, M.-E., D. Guétard and J.-M. Béchet, Random cleavage of intranuclear herpes simplex virus DNA by micrococcal nuclease

Möttönen, A. and P. Mäntsälä, Immunological study of glutamate synthase and its subunits

Moudgil, V.K. and G.A. Weekes, Inhibition of hen oviduct estradiol receptor by aurintricarboxylic acid

Moult, J., see M. Shoham

Mozzi, R. and G. Porcellati, Conversion of phosphatidyl-ethanolamine to phosphatidylcholine in rat brain by the methylation pathway

Muhlrad, A., A. Eldor and I. Kahane, Distribution of myosin, actin and actin-binding protein in membrane and soluble fraction of human blood platelets

Mukai, J.-I., see A. Razzaque

Mukohata, Y., see Y. Sugiyama

Mulder, E., J.A. Foekens, M.J. Peters and H.J. van der Molen, A comparison of heparin agarose and DNA cellulose for the characterization and partial purification of androgen receptors from rat prostate

Müller, J.J., see P. Plietz

Müller, M., see A. Wahlländer

Müller, M., see S. Soboll

Müller, W.E.G., R.K. Zahn and J. Arendes, Differential mode of inhibition of terminal deoxynucleotidyl transferase by 3 '-dATP, ATP, $\beta$ araATP and $\alpha$ araATP

Mulquet, M., see R. Schyns

Murao, S., see A. Razzaque

Murakami, K., see S.-i. Ejiri

Murakami, K., S.-i. Ejiri and T. Katsumata, Elongation factor 1 from the silk gland of silkworm. Effect of EF-Ib on EF-1 a- and ribosome-dependent GTPase activity

Murakami, K., see S.-i. Ejiri

Muranov, A.V., see T.A. Muranova

Muranova, T.A., A.V. Muranov, L.F. Markova and Yu.A Ovchinnikov, The primary structure of ribosomal protein L3 from Escherichia coli $70 \mathrm{~S}$ ribosomes

Murfitt, R.R., see S. Joshi

Muñoz-Clares, R., J.P. Garcia-Ruiz, A. Vargas and F. Sanchez-Medina, Effect of short-term exercise on the content of gluconeogenic metabolites in rat liver and kidney

Mvé Akamba, L.M. and P.-A. Siegenthaler, Effect of linolenate on photosynthesis by intact spinach chloroplasts. Conditions for the inhibition of orthophosphate uptake

Naccache, P.H., see R.J. Petroski

Nagai, K., T. Nakamura and J. Koyama, Characterization of macrophage proteases involved in the ingestion of antigen - antibody complexes by the use of protease inhibitors

Nagai, K. and H. Hori, The influence of quaternary structure on the EPR spectra of ferric haemoglobin

Nagamine, Y., D. Mizuno and S. Natori, Selective inhibition by zinc of RNA synthesis initiation in the RNA polymerase I reaction

Nagaraj, R. and P. Balaram, A stereochemically-constrained enkephalin analog. $\alpha$-Aminoisobutyryl ${ }^{2}$ methionine ${ }^{s}$ enkephalinamide

Nagaraj, R., see Ch. Pulla Rao

Nagashima, M., sce K. Edwards

Nagy, K., see Zs. Dancsházy

Nairn, A.C., see P. Cohen

Nakamura, S., see C. Ishikawa

Nakamura, T., see $K$. Nagai

Nakanishi, Y., K. Sekimizu, D. Mizuno and S. Natori, Apparent difference in the way of RNA synthesis stimulation by two stimulatory factors of RNA polymerase II

Nakashima, Y., see B. Frangione

Nalbandyan, R.M., see V.S. Gasparov

Nanni, G., M.A. Pronzato, M.M. Averame, G.R. Gambella, D. Cottalasso and U.M. Marinari, Influence of acute ethanol intoxication on rat liver golgi apparatus glycosylation activities

Naoki, Y., see S.-i. Ejiri
98 (1979) 309

98 (1979) 333

$100(1979) \quad 81$

$100(1979) 107$

91 (1978) 365

94 (1978) 324

95 (1978) 54

$100(1979) 363$

92 (1978) 85

93 (1978) 335

98 (1979) 276

97 (1979) 260

91 (1978) 230

97 (1979) 138

$100(1979) 125$

94 (1978) 47

93 (1978) 47

93 (1978) 335

92 (1978) 251

92 (1978) 255

95 (1978) 277

96 (1978) 301

96 (1978) 301

98 (1979) 13

99 (1979) 340

99 (1979) 6

100 (1979) 161

92 (1978) 299

93 (1978) 275

99 (1979) 29

$96(1978) 277$

100 (1979) 244

100 (1979) 269

96 (1978) 59

92 (1978) 287

99 (1979) 97

92 (1978) 299

93 (1978) 357

96 (1978) 381

97 (1979) 37

93 (1978) 242

95 (1978) 277 
Narayanan, R. and P. Balaram, Homologous cholinergic fluorescent probes. Synthesis and fluorescence properties

Nascimento, O.R., see E. Wajnberg

Nash-Adler, P., see C.F. Louis

Nasrulhaq-Boyce, A., see R.J. Fido

Nath. J. and M. Flavin, A structural difference between cytoplasmic and membrane-bound tubulin of brain

Natori, S, see Y. Nakanishi

Natori, S., see Y. Nagamine

Naumova, L.P., see V.G. Budker

Neal, W., see M.E. Wilson

Neat, C.E., see H. Osmundsen

Neeff, J., see S. Hartmann

Neeleman, L. and L. van Vloten-Doting, Excess of micrococcal nuclease may harm the exogenous mRNA in the mRNA-dependent rabbit reticulocyte cell-free system

Negreanu, V., see M.D. Walker

Nelson, B.D., see I. Mendel-Hartvig

Nelson, B.D., see A. Wielburski

Nelson, N., see D. Ralt

Neurath, H., see J.D. Londsdale-Eccles

Neurwirt, J., see P. Ponka

Nezlin, R.S., see L. Cser

Ngoc, L.D., G. Jebeleanu and O. Bârzu, Interaction of sulfur-containing ATP analogs with rabbit muscle phosphofructokinase

Nicholls, D.G., see M.D. Brand

Nicholls, P., see J.M. Wrigglesworth

Nicolau, C., see A.-C. Roche

Nielsen, O.F., see C. Tsopanakis

Nielsen, P.E., V. Leick and O. Buchardt, On photoaffinity labeling of Escherichia coli ribosomes using an azidochloramphenicol analogue

Niessing, J., see S. Koch

Nieuwenhuizen, W., see I.A.M. van Ruijven-Vermeer

Nieuwenhuizen, W., A. Vermond, W.J. Nooijen and F. Haverkate, Calcium-binding properties of human fibrin(ogen) and degradation products

Nieuwenhuysen, P. and H. Slegers, Preparative centrifugation of Artemia salina ribosomes in high density sucrose gradients

Nikaido, H., see H. Sanderman, jr

Nikawa, J.-I., S. Numa, T. Shiba, C.J. Stewart and T. Wieland, Carboxylation of acetonyldethio-coenzyme A by acetyl coenzyme $A$ carboxylase

Nikkilä, E.A., see T. Kussi

Nikolaev, L.G., see B.O. Glotov

Nishikawa, S., see M. Sugiura

Nishikimi, M., see W.C. Kenney

Nishino, T., see A. Razzaque

Nishioka, Y., U. Nudel, F. Ramirez and S. Silverstein, Differential stability of $\alpha$ - and $\beta$-globin mRNAs after infection with herpes simplex virus

Niveleau, A. and G.A. Quash, The effect of anti-spermine antibodies on a wheat germ cell-free proteinsynthesizing system

Nixdorff, K., H.H. Martin, S. Rottem and S. Razin, EPR studies on model membranes of phospholipid and outer membrane proteins of Proteus mirabilis

Nobili, O., see J. Arnaud

Noff, D., see M. Sheves

Noguchi, E., see W.C. Kenney

Noguchi, M., T. Yoshida and G. Kikuchi, Specific requirement of NADPH-cytochrome $c$ reductase for the microsomal heme oxygenase reaction yielding biliverdin IXa

Noller, H.F., see D.G. Bear

Nooijen, W.J., see I.A.M. van Ruijven-Vermeer

Nooijen, W.J., see W. Nieuwenhuizen

93 (1978) 38

91 (1978) 257

93 (1978) 61

99 (1979) 180

95 (1978) 335

93 (1978) 357

99 (1979) 29

95 (1978) 143

94 (1978) 387

99 (1979) 292

93 (1978) 339

95 (1978) 103

98 (1979) 187

92 (1978) 36

93 (1978) 69

91 (1978) 85

100 (1979) 157

97 (1979) 317

93 (1978) 312

97 (1979) 65

95 (1978) 125

91 (1978) 190

93 (1978) 91

93 (1978) 297

94 (1978) 287

96 (1978) 354

93 (1978) 177

98 (1979) 257

93 (1978) 200

95 (1978) 107

91 (1978) 144

98 (1979) 314

91 (1978) 149

97 (1979) 73

97 (1979) 40

93 (1978) 335

92 (1978) 283

99 (1979) 20

94 (1978) 298

99 (1979) 43

96 (1978) 75

97 (1979) 40

98 (1979) 281

100 (1979) 99

93 (1978) 177

98 (1979) 257 


\section{FEBS LETTERS}

Noordam, A., see K.H. Dahl

99 (1979) 308

Noordam, A., see K.H. Dahl

Nordén, B., Rearrangement of a platinum(II) complex in DNA from intercalation outer-sphere position to non-intercalation coordination

Nordenberg. J., see R. Beitner

Nordin, I., see G. Cederblad

Norne, J.-E., E. Chiancone, S. Forsen, E. Antonini and J. Wyman, ${ }^{35} \mathrm{Cl}$ NMR study of the release of chloride on oxygen binding to human hemoglobin

Norris, J.R, see M.C. Thurnauer

Norseth, J., E.N. Christiansen and B.O. Christophersen, Increased chain shortening of erucic acid in perfused heart from rats fed rapeseed oil

Norum, K.R., see H. Osmundsen

Nose, K., see N. Itoh

Notton, B.A., see J.M. Maldonado

Notton, B.A., see R.J. Fido

Novotný, J., see L. Cser

Nozaki, C., see S. Kawamoto

Nozaki, M., see T. Yagi

Nozari, G., S. Rahbar and H. Lehmann, Haemoglobin Coventry ( $\beta 141$ deleted) in Iran

Nudel. U., see Y. Nishioka

Numa, S., see J.-I. Nikawa

Nygard, O., see P. Westermann

Nylén, A., see Efendić

Oberley, L.W. and G.R. Buettner, The production of hydroxyl radical by bleomycin and iron (II)

Oberley, L.W., see G.R. Buettner

Obrenovitch, A., see A.-C. Roche

Öchsner, I., see D. Brauer

Oda, T., see Y. Sato

Oftebro, R., see M. Gacek

Ogurusu, T., see A. Maeda

Ohashi, K., see H. Tsuge

Ohlenschläger, G., see G. Zimmer

Ohlson, S., L. Hansson, P.-O. Larsson and K. Mosbach, High performance liquid affinity chromatography

(HPLAC) and its application to the separation of enzymes and antigens

Ohmori, D., see T. Hase

Ohnishi, S.-i., see T. Maeda

Ohno-Iwashita, Y. and K. Imahori, Comparative studies on the structures of colicins E2 and E3

Ohta, M., see A. Lundblad

Ohtsuka, E., see M. Sugiura

Ohuchi, T., see E. Tachikawa

Oka, M., see E. Tachikawa

Okada, Y., see K. Fujiki

Okada, Y., see A. Fukuda

Okada, Y., see H. Iida

Okahata, S., see Y. Kobayashi

Okamoto, H., see N. Itoh

Okolow-Zubkowska, M.J., see M.R. Green

Okonek, M., see G. Sander

Oliver, I.T., see P.N. Di Marco

Olorunsogo, O.O., E.A. Bababunmi and O. Bassir, Uncoupling of corn shoot mitochcndria by

$N$-(phosphonomethyl)glycine

Olson, J.M., see D.B. Knaff

Oppenheimer, N.J., The stereospecifity of pig brain NAD-glycohydrolase-catalyzed methanolysis of NAD ${ }^{+}$

Orlek, B.S., see V. Knott-Hunziker

Ormos, P., see Zs. Dancsházy

Oron, Y., J. Kellogg and J. Larner, Stable cholinergic-muscarinic inhibition of rat parotid adenylate cyclase

99 (1979) 313

94 (1978) 204

98 (1979) 199

98 (1979) 57

94 (1978) 410

100 (1979) 309

97 (1979) 163

99 (1979) 292

93 (1978) 343

93 (1978) 169

99 (1979) 180

93 (1978) 312

96 (1978) 37

100 (1979) 81

95 (1978) 88

92 (1978) 283

91 (1978) 144

97 (1979) 101

92 (1978) 33

97 (1979) 47

98 (1979) 18

93 (1978) 91

96 (1978) 317

98 (1979) 271

98 (1979) 355

92 (1978) 77

93 (1978) 331

94 (1978) 223

93 (1978) 5

91 (1978) 315

98 (1979) 157

100 (1979) 249

97 (1979) 249

97 (1979) 73

100 (1979) 331

100 (1979) 331

91 (1978) 81

95 (1978) 70

99 (1979) 346

98 (1979) 391

93 (1978) 343

100 (1979) 23

98 (1979) 111

94 (1978) 183

97 (1979) 279

98 (1979) 285

94 (1978) 368

99 (1979) 59

96 (1978) 59

94 (1978) 331 
Orre, K., see W.W. Fish

Osborne, W.C., see A.S. Inglis

Osmundsen, H., C.E. Neat and K.R. Norum, Peroxisomal oxidation of long chain fatty acids

Osipova, T.I., see A.I. Biryukov

Osmond, B.C., see L.M. Hall

Ostanevich, Yu.M., see L. Cser

Österberg, R., B. Sjöberg and J. Littlechild, Small-angle X-ray scattering study of the proteins S1, S8, S15, S16, S20 from Escherichia coli ribosomes

O'Sullivan, M.J., E. Gnemmi, D. Morris, G. Chieregatti, M. Simmons, A.D. Simmonds, J.W. Bridges and V. Marks, A simple method for the preparation of enzyme - antibody conjugates

Otani, S., see I. Horvath

Otten, U., see H. Hatanaka

Otto, B., see A. Richter

Ovchinnikov, L.P., see S.P. Domogatsky

Ovchinnikov, Yu.A., see T.A. Muranova

Ovchinnikov, Yu.A., A.M. Shkrob, A.V. Rodionov and B.I. Mitzner, An effective competitive inhibitor of bacterioopsin-retinal recombination

Ovchinnikov, Yu.A., N.G. Abdulaev, M.Yu. Feigina, A.V. Kiselev and N.A. Lobanov, The structural basis of the functioning of bacteriorhodopsin: An overview

Ovchinnikov, Yu.A., V.A. Efimov and O.G. Chakhmakhcheva, Synthesis of a polynucleotide corresponding to the promoter region of bacteriophage fd DNA

Oya, M., see Y. Katsumata

Packer, L., see T. Konishi

Packer, L., see R. Cammack.

Packer, L., see L.Y.L. Cheng

Packman, L.C. and D.J.H. Smith, A simplified route to $\left[{ }^{14} \mathrm{C}\right]$ dimethylsuberimidate for polypeptide crosslinking studies; synthesis of $\left[{ }^{14} \mathrm{C}\right]$ suberonitrile by phase transfer catalysis using 18 -crown-6 ether

Padan, E., see S. Belkin

Paehtz, W., see P. Plietz

Paetzke-Brunner, I., H. Schön and O.H. Wieland, Insulin activates pyruvate dehydrogenase by lowering the mitochondrial acetyl-CoA/CoA ratio as evidenced by digitonin fractionation of isolated fat cells

Pajula, R.-L. and A. Raina, Methylthioadenosine, a potent inhibitor of spermine synthase from bovine brain

Palacios, J. and R. Serrano, Proton permeability induced by polyene antibiotics. A plausible mechanism for their inhibition of maltose fermentation in yeast

Pallmann, B., see T. Miyatake

Palmer, J.M., see S. Huq

Palmer, J.M., see L.E.A. Henry

Palmer, J.M., see S. Huq

Paltauf, F., see P. Somerharju

Palukaitis, P. and R.H. Symons, Synthesis and characterization of a complementary DNA probe for chrysanthemum stunt viroid

Palva, E.T. and P. Westermann, Arrangement of the maltose-inducible major outer membrane proteins, the bacteriophage $\lambda$ receptor in Escherichia coli and the $44 \mathrm{~K}$ protein in Salmonella typhimurium

Panzali, A., see S. Leoni

Papa, S., see G. Izzo

Parello, J., see T. Drakenberg

Parello, J., see A. Kervabon

Parello, J., see A. Cave

Parello, J., P. Reimarsson, E. Thulin and B. Lindman, $\mathrm{Na}^{+}$binding to parvalbumins studied by ${ }^{23} \mathrm{Na} \mathrm{NMR}$

Parish, C.R, see R.W. Parish

Parish, R.W., S. Schmidlin and C.R. Parish, Detection of developmentally controlled plasma membrane antigens of Dictyostelium discoideum cells in SDS - polyacrylamide gels

Parish, R.W.. S. Schmidlin and M. Weibel, Effect of cyclic AMP pulses on the synthesis of plasma membrane proteins in aggregateless mutants of Dictyostellium discoideum

Parish, R.W. and S. Schmidlin, Synthesis of plasma membrane protein during development of Dictyostelium discoideum

98 (1979) 103

97 (1979) 179

99 (1979) 292

91 (1978) 246

95 (1978) 243

93 (1978) 312

$93(1978) 115$

95 (1978) 311

$98(1979) \quad 49$

92 (1978) 313

91 (1978) 293

96 (1978) 207

$96(1978) 301$

97 (1979) 15

$100(1979) 219$

100 (1979) 341

$93(1978) \quad 58$

92 (1978) 1

93 (1978) 278

97 (1979) 124

91 (1978) 178

94 (1978) 291

91 (1978) 227

93 (1978) 307

99 (1979) 343

91 (1978) 198

97 (1979) 257

92 (1978) 317

93 (1978) 327

95 (1978) 217

96 (1978) 170

$92(1978) 268$

99 (1979) 77

92 (1978) 63

93 (1978) 320

92 (1978) 346

98 (1979) 152

100 (1979) 148

100 (1979) 153

95 (1978) 366

95 (1978) 366

$96(1978) 283$

98 (1979) 251 


\section{FEBS LETTERS}

Parish, R.W. and S. Schmidlin, Resynthesis of developmentally regulated plasma membrane proteins following disaggregation of Dictyostelium pseudoplasmodia

Park, B.K. and A.D. Whittaker, An immunochemical study of the hapten formed from ethynyloestradiol and guinea pig liver microsomes

Parker, P.J. and P.J. Randle, Inactivation of rat heart branched-chain 2-oxoacid dehydrogenase complex by adenosine triphosphate

Parmeggiani, A., see G. Sander

Pascher, I., see K.-A. Karlsson

Pastan, I., see S.-y. Cheng

Pato, M.D., see G.P. Côté

Patrushev, L.I., see M.F. Shemyakin

Paulsen, R. and I. Hoppe, Light-activated phosphorylation of cephalopod rhodopsin

Pavlovsky, A.G., S.N. Borisova, V.V. Borisov, I.V. Antonov and M.Ya. Karpeisky, The structure of the complex of ribonuclease $S$ with fluoride analogue of $U p A$ at $2.5 \AA$ resolution

Pearson, A.G.M. and A.J. Turner, The formation of $\beta$-carboline alkaloids mediated by serine hydroxymethyltransferase

Pecht, I., see O. Farver

Pecquery, R., L. Malagrida and Y. Giudicelli, Direct biochemical evidence for the existence of $\alpha$-adrenergic receptors in hamster white adipocyte membranes

Pedersen, J.I., I. Holmberg and I. Björkhem, Reconstitution of vitamin $D_{3}$ 25-hydroxylase activity with a cytochrome $P-450$ preparation from rat liver mitochondria

Pegoraro, B., A.A. Ansari, C.-Y. Lee and R.P. Erickson, Immunological relatedness of two isozymes of 3-phosphoglycerate kinase from the mouse

Pelham, H.R.B., Transiation of fragmented viral RNA in vitro: initiation at multiple sites

Pellin, M.J., see J.M. Fenton

Perahia, D., see A. Goldblum

Perez Bercoff, R. and M. Gander, In vitro translation of mengovirus RNA deprived of the terminally-linked (capping?) protein

Périn, J.-P., F. Bonnet and P. Jollés, The action of trypsin on purified link proteins from bovine nasal cartilage proteoglycan complex

Perlo, C., see A. Ceccarelli

Perry, S.V., see R.J.A. Grand

Peterlik, M., see R. Fuchs

Peters, M.J., see E. Mulder

Peters, W.H.M., see F.A.M. Asselbergs

Petersen, L.Chr., Cytochrome $c$ - cytochrome $a a_{3}$ complex formation at low ionic strength studied by aqueous two-phase partition

Peterson, B.L., see J.A. Kulkoski

Petersson, L., see T. Ljones

Petroski, R.J., P.H. Naccache, E.L. Becker and R.I. Sha'afi, Effect of the chemotactic factor formyl methionyl-leucyl-phenylalanine and cytochalasin $\mathrm{B}$ on the cellular levels of calcium in rabbit neutrophils

Pettersson, I. and A. Liljas, The stoichiometry and reconstruction of a stable protein complex from Escherichia coli ribosomes

Pettersson, L.G., see L.G. Fägerstam

Petty, K.M. and J.B. Jackson, Two protons transferred per ATP synthesised after flash activation of chromatophores from photosynthetic bacteria

Peypoux, F., see C. Garbay-Jaureguiberry

Pflugfelder, G. and J. Sonnenbichler, A rapid purification method for DNA-dependent RNA-polymerase $B$ from rat liver

Phethean, J., see J.C. Pinder

Philippe, M., see M.K. Agarwal

Phillips, C.A., E.Z. Girit and J.E. Kay, Changes in intracellular prostaglandin content during activation of lymphocytes by phytohaemagglutinin

Phillips, D., see A.G. Lee

Phillips, J.A., iii, D.M. Sedlak, T.-c. Cheng and H.H. Kazazian, jr, Ratios of $\alpha$ - to $\beta$-globin RNA sequences in the erythropoietic mouse spleen

Pickard, M.R. and J.N. Hawthome, Does myo-inositol specifically interact with brain microtubules?

99 (1979) 270

91 (1978) 273

95 (1978) 153

98 (1979) 111

94 (1978) 413

100 (1979) 113

94 (1978) 131

91 (1978) 253

96 (1978) 55

92 (1978) 258

98 (1979) 96

94 (1978) 383

98 (1979) 241

98 (1979) 394

95 (1978) 371

100 (1979) 195

100 (1979) 1

91 (1978) 213

96 (1978) 306

94 (1978) 257

93 (1978) 348

92 (1978) 137

100 (1979) 357

97 (1979) 260

94 (1978) 195

94 (1978) 105

99 (1979) 183

92 (1978) 81

100 (1979) 161

98 (1979) 139

98 (1979) 363

97 (1979) 367

93 (1978) 151

93 (1978) 361

92 (1978) 278

93 (1978) 129

94 (1978) 115

94 (1978) 171

97 (1979) 327

93 (1978) 78 
Pierre, M., see R. Counis

Pietruszko, R. and R.C. Vallari, Aldehyde dehydrogenase in human blood

Pinder, J.C., J. Phethean and W.B. Gratzer, Spectrin in primitive erythrocytes

Pinna, L.A., see F. Meggio

Pirinu, F., see J. Vičar

Pirker, R., see J. Spona

Pirollet, F., see D. Job

Pirrwitz, J., see R. Renneberg

Plietz, P., H. Damaschun, D. Zirwer, K. Gast, K.D. Schwenke, W. Paehtz and G. Damaschun, Small-angle $\mathrm{X}$-ray and quasi-elastic light scattering studies on $11 \mathrm{~S}$ globulin from sunflower seed

Plietz, P., G. Damaschun, G. Kopperschläger and J.J. Müller, Small-angle X-ray scattering studies on the quatemary structure of phosphofructokinase from baker's yeast

Plowman, D., see M.C. Botha

Pluskal, M.G., see S.K. Jain

Podder, S.K., see P.D. Thomas

Podenphant, J., see M. Treiman

Podo, F., see R. Strom

Pogorelov, V.M., see B.Yu. Zaslavsky

Pohjanpelto, P., see E. Hölttă

Pohka, P., J. Borová, J. Neuwirt and O. Fuchs, Mobilization of iron from reticulocytes. Identification of pyridoxal isonicotinoyl hydrazone as a new iron chelating agent

Pope, A.J., N. Mian and D.G. Herries, Kinetic evidence for two types of active site in the $N$-acetyl- $\beta$-D hexosaminidase of bovine kidney

Porat, N., G. Ben-Hayyim and I. Friedberg, The site of ferricyanide photoreduction in pea chloroplasts pretreated by silicomolybdic acid

Porcellati, G., see R. Mozzi

Porta, R., see V. Zappia

Pösö, A.R. and H. Pösö, Relationship between the phosphorylation state and the rate of ethanol elimination in regenerating rat liver

Pösô, H., see A.R. Pösö

Pospelov, V.A., S.B. Svetlikova and V.I. Vorob'ev, Nucleosome - nucleosome interaction in chromatin

Possani, L.D., G.A. Ramirez, P.L. Fletcher, jr and M.A.H. Gurrola, Isolation of two mammalian toxins from the venom of the Mexican scorpion Centruroides elegans (Thorell)

Postlethwait, J.H. and R. Kaschnitz, The synthesis of Drosophila melanogaster vitellogenins in vivo, in culture, and in a cell-free translation system

Poulsen, F.M., see J.L. Costa

Poulsen, K., J. Vuust, S. Lykkegaard, A. Høj Nielsen and T. Lund, Renin is synthesized as a 50000 dalton single-chain polypeptide in cell-free translation systems

Pregnolato, L., see G.F. Azzone

Pregnolato, L., see G.F. Azzone

Preissler, M., see H.P. Meissner

Price, R.C., see D.B. Knaff

Prihar, H.S. and D.S. Feingold, Loss of C-5 hydrogen during oxidation of UDP-D-glucose by UDP-D-glucose dehydrogenase

Prince, R.C., see P.L. Dutton

Prince, R.C., see C.L. Bashford

Privalov, P.L., see E.I. Tiktopulo

Pronzato, M.A., see G. Nanni

Ptitsyn, O.B., Inter-domain mobility in proteins and its probable functional role

Pucheu, N.L., see N.L. Kerber

Puente, J., M.A. Varas, G. Beckhaus and M. Sapag Hagar, $\gamma$-glutamyltranspeptidase activity and cyclic AMP levels in rat liver and mammary gland during the lactogenic cycle and in the oestradiol - progesterone pseudo-induced pregnancy

Puijk, W.C., see A.J. Slotboom

Pulla Rao, Ch., R. Nagaraj, C.N.R. Rao and P. Balaram, Infrared spectroscopy as a probe for the development of secondary structure in the amino-terminal segment of alamethicin

Pullman, A., see A. Goldblum

96 (1978) 69

92 (1978) 89

92 (1978) 278

91 (1978) 216

97 (1979) 275

97 (1979) 269

98 (1979) 303

96 (1978) 349

91 (1978) 227

91 (1978) 230

96 (1978) 331

97 (1979) 84

96 (1978) 90

97 (1979) 147

96 (1978) 45

94 (1978) 77

97 (1979) 9

97 (1979) 317

93 (1978) 174

92 (1978) 9

100 (1979) 363

94 (1978) 161

100 (1979) 273

100 (1979) 273

$99(1979) 123$

91 (1978) 261

95 (1978) 247

99 (1979) 141

98 (1979) 135

96 (1978) 135

96 (1978) 141

94 (1978) 87

98 (1979) 285

99 (1979) 106

91 (1978) 15

97 (1979) 55

91 (1978) 57

93 (1978) 242

93 (1978) 1

94 (1978) 265

99 (1979) 215

92 (1978) 361

100 (1979) 244

91 (1978) 213 


\section{FEBS LETTERS}

Purich, D.L. and R.K. MacNeal, Properties of tubulin treated with alkaline phosphatase to remove guanine nucleotides from the exchangeable binding site

Pusyriov, A.T., see V.V. Vlassov

96 (1978) 83

$94(1978) 157$

Quagliariello, E., see G.V. Gnoni

94 (1978) 179

Quash, G.A., see A. Niveleau

Quesada Allue, L.A., Phosphorylation of dolichol by insect enzymes: The incorporation of phosphate from ATP into dolichyl phosphate mannose

Quintanilha, A.T. and R.J. Mehlhorn, pH gradients across thylakoid membranes measured with a spin-labeled amine

Quirk, S.J., see Q.F. Ahkong

Rabin, B.R., see J.A. Craft

Rader, J.H., see I.L. Flink

Rafferty, C.N., see W. Sperling

Rahamimoff, $\mathrm{H}$. and E. Abramovitz, Ca transport and ATPase activity of synaptosomal vesicles from rat brain

Rahbar, S., see G. Nozari

Raina, A., see R.-L. Pajula

Ralt, D., N. Nelson and D. Gutnick, Specific immunoprecipitation of ATPase from Escherichia coli

Ramensky, E.V., see L.N. Viktorova

Ramirez, F., see Y. Nishioka

Ramirez, G.A., see L.D. Possani

Ramm, K., see H.L. Sänger

Randle, P.J., see N.J. Hutson

Randle, P.J., see P.J. Parker

Rao, C.N.R., see Ch. Pulla Rao

Rao, K.K., see T. Hase

Rao, K.K., see M.J. Llama

Rapaka, R.S., see R.S. Bhatnagar

Rapoport, S., see P. Ludwig

Rathnam, C.K.M., Studies with isolated bundle sheath mitochondria: evidence for NAD-malic enzyme-catalyzed decarboxylation of $\mathrm{C}_{4}$ acids in species representing the tree $\mathrm{C}_{4}$ metabolic subtypes

Rauch, B., D. v. Chak and W. Hasselbach, An estimate of the kinetics of calcium binding and dissociation of the sarcoplasmic reticulum transport ATPase

Rauschenbach, P., see H. Sedlmaier

Rauvala, H., see K.-A. Karlsson

Rauvala, H. and J. Finne, Structural similarity of the terminal carbohydrate sequences of glycoproteins and glycolipids

Ravel, J.M., see D. Dottavio-Martin

Ravid, A., see C.M.T. Kieda

Ray, T.K., Gastric $\mathrm{K}^{\dagger}$-stimulated adenosine triphosphatase. Demonstration of an endogenous activator

Rayner, D.M., see A.G. Szabo

Razin, S., see K. Nixdorff

Razzaque, A., Y. Hanada, J.-I. Mukai, S. Murao and T. Nishino, NAD- and FAD-3'-pyrophosphates enzymic synthesis and inertness

Reboud, J.P., see A. Genot

Reboul, A., see R.B. Sim

Recasens, M., R. Benezra, M.M. Gabellec, J.P. Delaunoy and P. Mandel, Purification and some properties of cysteine sulfinate transaminase

Reddington, M.A. and W.P. Tate, A polypeptide chain release factor from the undeveloped cyst of the brine shrimp, Artemia salina

Redel, J., N. Bazely, Y. Tanaka and H.F. DeLuca, The absolute configuration of the natural 25,26-dihydroxycholecalciferol

Redel, J., L. Miravet, Y. Calando and M. Carre, The biological activity of 26-hydroxy-derivatives of cholecalciferol in vitamin D-deficient rats

Redfield, A.G., see J.D. Ștoesz

Rees, J.S., see M.C. Botha

99 (1979) 20

97 (1979) 225

91 (1978) 104

95 (1978) 147

98 (1979) 403

94 (1978) 125

97 (1979) 129

92 (1978) 163

95 (1978) 88

99 (1979) 343

91 (1978) 85

91 (1978) 194

92 (1978) 283

91 (1978) 261

99 (1979) 117

92 (1978) 73

95 (1978) 153

100 (1979) 244

$96(1978) \quad 41$

98 (1979) 342

95 (1978) 61

95 (1978) 181

96 (1978) 367

93 (1978) 65

100 (1979) 129

94 (1978) 413

97 (1979) 1

97 (1979) 105

94 (1978) 391

92 (1978) 49

94 (1978) 249

94 (1978) 298

93 (1978) 335

99 (1979) 261

97 (1979) 111

99 (1979) 51

97 (1979) 335

94 (1978) 228

96 (1978) 216

91 (1978) 320

96 (1978) 331 
Reeve, J.N., see A.R. Subramanian

Reeves, R. and E.P.M. Candido, Turnover of histone acetyl groups in cultured cells is inhibited by sodium butyrate

Regts, J, see J.C. Wilschut

Reichmann, G., see B. Rüstow

Reilly, P.E.B. and D.E. Ivey, Inhibition by chloramphenicol of the microsomal monooxygenase complex of rat liver

Reimarsson, P., see J. Parello

Reinbolt, J., D. Tritsch and B. Wittmann-Liebold, The primary structure of ribosomal protein $\mathrm{S} 7$ from $E$. colt strains $\mathrm{K}$ and $\mathrm{B}$

Remington, J.A., Attenuation as a general mechanism for the regulation of differential gene transcription in eukaryotes

Renneberg, R., F. Scheller, K. Ruckpaul, J. Pirrwitz and P. Mohr, NADPH and $\mathrm{H}_{2} \mathrm{O}_{2}$-dependent reactions of cytochrome $P-450_{L M}$ compared with peroxidase catalysis

Renner, R., see K.D. Hepp

Renner, R., see H.U. Häring

Rennie, R.J., A. Funnell and B.E. Smith, Immunochemistry of nitrogenase as a probe for the enzyme mechanism. Evidence for multiple enzyme forms and an $\mathrm{MgATP}^{2+}$-binding site on the MoFe protein

Reshef, L., D. Faliks, V. Bentor-Getter and G. Glaser, Effect of glucose feeding to fasted rats on the translational efficiency of liver cytosol phosphoenolpyruvate carboxykinase mRNA

Restall, C., see J.C. Gómez-Fernández

Rether, B., A. Belarbi and G. Beck, Translation of tyrosine aminotransferase mRNA from hepatoma cells in a wheat germ cell-free system

Reuben, J., Chemically-selective nucleotide - amino acid interactions in aqueous solution. A PMR study

Revel, M., see D. Gurari-Rotman

Revel, M., see A. Schmidt

Rezvan, H., see R.M. Howell

Ribbing, W., D. Krümpelmann and H. Rüterjans, Isomeric incorporation of the haem group into two monomeric haemoglobins of Chironomus thummi thummi. A nuclear magnetic study

Ribeiro, P.C., see E. Wajnberg

Rice-Evans, C., K.R. Bruckdorfer and G. Dootson, Studies on the altered membrane characteristics of sickle cells

Rich, P.R., J.C. Salerno, J.S. Leigh and W.D. Bonner, jr, A spin $3 / 2$ ferrous - nitric oxide derivative of an iron-containing moiety associated with Neurospora crassa and higher plant mitochondria

Rich, P.R., Quinol oxidation in Arum maculatum mitochondria and its application to the assay, solubilisation and partial purification of the alternative oxidase

Richter, A., R. Knippers and B. Otto, Interaction of a mammalian single strand specific DNA binding protein with DNA polymerase a

Richter, D. and M. Geis, Isolation of a pyrophosphorylase from Bacillus sutbilis and Bacillus stearothermophilus that specifically degrades guanosine 3'-diphosphate 5 '-diphosphate

Richter, D., see S. Fehr

Richter, W., see P. Schwandt

Richter-Landsberg, C., see I. Gozes

Ricquier, D., J.L. Gaillard and J.M. Turc, Microcalorimetry of isolated mitochondria from brown adipose tissue. Effect of guanosine-di-phosphate

Rieder, R. and H.R. Bosshard, Cytochrome $b c_{1}$ and cytochrome oxidase can bind to the same surface domain of the cytochrome $c$ molecule

Riemen, M.W., see A.J. Fischman

Riesen, W.F., R.C. Mordasini and G.W. Middelhoff, Quantitation of the two major apoproteins of human high density lipoproteins by solid phase radioimmunoassay

Riesner, D., see H.L. Sänger

Righetti, P.G., see R. Krishnamoorthy

Rigo, A., see F. Marmocchi

Rinninger, J., see K.D. Hepp

Robberrecht, P., see M. Svoboda

Robbins, J., see S.-y. Cheng

91 (1978) 117

98 (1979) 181

95 (1978) 225

97 (1979) 141

100 (1979) 153

91 (1978) 297

$100(1979) 225$

96 (1978) 349

91 (1978) 325

95 (1978) 177

$91(1978) 158$

97 (1979) 96

98 (1979) 224

93 (1978) 194

94 (1978) 20

94 (1978) 187

95 (1978) 257

97 (1979) 23

92 (1978) 105

91 (1978) 257

94 (1978) 81

93 (1978) 323

96 (1978) 252

91 (1978) 293

96 (1978) 247

97 (1979) 91

100 (1979) 360

95 (1978) 169

99 (1979) 203

92 (1978) 223

94 (1978) 236

91 (1978) 35

99 (1979) 117

94 (1978) 319

94 (1978) 109

91 (1978) 325

92 (1978) 351

100 (1979) 113 
Roberts, F.M., H.A.I. McArthur, I.C. Hancock and J. Baddiley, Biosynthesis of the linkage unit joining peptidoglycan to poly( $N$-acetylglucosamine 1-phosphate) in walls of Micrococcus varians ATTC 29750

Roberts, G.C.K., see J. Degelaen

Roberts, R.M., see M.N. Horst

Robinson, S.P., P.H. McNeil and D.A. Walker, Ribulose bisphosphate carboxylase - lack of dark inactivation of the enzyme in experiments with protoplasts

Roche, A.-C., J.-C. Maurizot and M. Monsigny, Circular dichroism of limulin: Limulus polyphemus lectin

Roche, A.-C., R. Maget-Dana, A. Obrenovitch, K. Hildenbrand, C. Nicolau and M. Monsigny, Interaction between vesicles containing gangliosides and limulin (Limulus polyphemus lectin). Fluorescence polarization of 1,6-diphenyl-1,3,5-hexatriene

Roche, A.C., see C. Kieda

Rochette-Egly, C., see M. Castagna

Rocquet, G., see P. Bernard

Roda, L.G., see M. Tomasi

Rodionov, A.V., see Yu.A. Ovchinnikov

Rodionov, V.I., see S.A. Kuznetsov

Rodionov, V.I., see S.A. Kuznetsov

Rodkey, L.S., see J.K. Wright

Rodrigues, L.M., see P.D. Whitton

Rogers, J., see A.G. Lee

Rogers, T.B. and M. Lazdunski, Photoaffinity labelling of a small protein component of a purified $\left(\mathrm{Na}^{\prime}-\mathrm{K}^{\prime}\right)$ ATPase

Rogozhin, S.V., see B.Yu. Zaslavsky

Röhm, K.-H., see J. Frey

Rohr, G., see H.G. Mannherz

Rohr, G. and H.G. Mannherz, The activation of actin: DNase I complex with rat liver plasma membranes; the possible role of $5^{\prime}$-nucleotidase

Rolland, P.-H., see A. Margotat

Romano, S., see E. Clementi

Ronald, R., see K.-S. Boos

Ronin, C., S. Bouchilloux, C. Granier and J. van Rietschoten, Enzymatic $N$-glycosylation of synthetic Asn - X - Thr containing peptides

Roobol, K. and W. Möller, Transient interaction between elongation factor 1 from Artemia salina and the $80 \mathrm{~S}$ ribosome

Rooke, J.A., see C. Hay

Roos, I., M. Crompton and E. Carafoli, The effect of phosphoenolpyruvate on the retention of calcium by liver mitochondria

Roovete, A., see S. Efendic

Roques, B.P., see C. Garbay-Jaureguiberry

Rosenblat, V.A., see S.A. Kuznetsov

Rosenblat, V.A., see S.A. Kuznetsov

Rosenfeld, C., see M. Castagna

Rosenheck, K., see J. Granot

Rosenheck, K., see K. Tsuji

Rosselin, G., see M. Laburthe

Rossi, G.L., see E. Bignetti

Rosteck, P., jr, see V.R. Haynes

Rotilio, G., see F. Marmocchi

Rotilio, G., see A. Desideri

Rottem, S., see K. Nixdorff

Rottem, S., The effect of lipid A on the fluidity and permeability properties of phospholipid dispersions

Rottenberg, H., Phase transitions and coupling in energy transducing membranes

Rousseaux, J., H. Bazin and G. Biserte, Differences in sensitivity of rat immunoglobulin IgG subclasses

Rousselet, A. and P.F. Devaux, Interaction between spin-labeled phospholids in the retinal outer segment disc membranes

Rousset, M., see M. Laburthe

Ruckpaul, K., see R. Renneberg

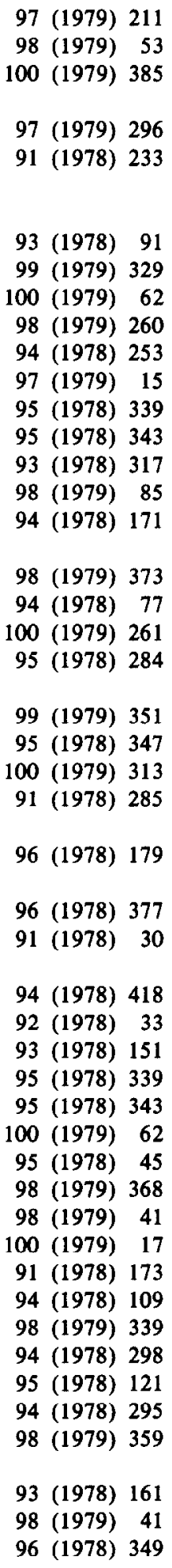


Ruis, H., see M. Barlas

92 (1978) 195

Ruis, H., see G. Ammerer

Runswick, M.J. and J.I. Harris, Purification of alcohol dehydrogenase from Bacillus stearothermophilus by affinity chromatography

Runswick, M.J. and J.I. Harris, A rapid procedure for the isolation of endonucleases from two thermophilic bacteria

Ruoslahti, E. and E. Hayman, Two active sites with different characteristics in fibronectin

Rupp, H., see A.L. Moore

Rüstow, B., J. Hodi, D. Kunze, G. Reichmann and E. Egger, Specific binding of saturated and unsaturated fatty acids on the ' $Z$ '-protein of rat liver cytosol

Ruterjans, $\mathbf{H}$, see W. Ribbing

Rüterjans, H., see F. Buck

Rutherford, A.W. and M.C.W. Evans, A high potential semiquinone - iron type electron paramagnetic resonance signal in $R$ hodopseudomonas viridis

Ruuge, E.K., see E.A. Imedidze

Rychik, I., see J. Jonák

Rylatt, D.B. and P. Cohen, Amino acid sequence at the site on rabbit skeletal muscle glycogen synthase phosphorylated by the endogenous glycogen synthase kinase- 2 activity

Rylatt, D.B., N. Embi and P. Cohen, Glycogen synthase kinase- 2 from rabbit skeletal muscle is activated by the calcium-dependent regulator protein

Sabatini, S., see M.T. Costa

Sack, D.H., see R.E. Fine

Sadler, P.J., A. Bakka and P.J. Beynon, ${ }^{113} \mathrm{Cd}$ nuclear magnetic resonance of metallothionein: non-equivalent CdS sites

Sabø, J. and P.M. Ueland, An adenosine $3^{\prime}: 5^{\prime}$-monophosphate adenosine-binding protein from mouse liver.

Association with $S$-adenosylhomocysteinase activity

Særmark, T., see M. Treiman

Sage, E., see M. Leng

Saggerson, E.D., see S.R. Sooranna

Saggerson, E.D., see C.H.K. Cheng

Saggerson, E.D., see S.R. Sooranna

Saggerson, E.D., see S.R. Sooranna

Saheki, K., see S. Saheki

Saheki, S., K. Saheki and T. Tanaka, Peptide mapping by limited proteolysis of four pyruvate kinase isozymes Saitô, H., see Y. Sato

Sakai, T.T. and J.L. Dallas, Synthesis and properties of a fluorine-containing sulfhydryl reagent for ${ }^{19}$ F NMR studies

Sakamoto, S., see S. Kitagawa

Sakano, T., see Y. Kobayashi

Salemo, J.C., see P.R. Rich

Salnikow, J., see M. Altmann

Sammes, P.G., see V. Knott-Hunziker

Samuelsson, B.E., see K.-A. Karisson

Sanadi, D.R., see S. Joshi

Sánchez, R.A., see A. Boveris

Sánchez-Medina, F., see R. Muñoz-Clares

Sander, G., Colicin E3 treatment renders ribosomes more resistant to streptomycin and reduces miscoding

Sander, G., M. Okonek, J.-B. Crechet, R. Ivell, V. Bocchini and A. Parmeggiani, Hydrolysis of GTP by the elongation factor $\mathrm{Tu} \cdot$ kirromycin complex: Specific action of monovalent cations

Sandermann, H., jr, P. Bavoil and H. Nikaido, Phage lambda receptor protein from Escherichia colt: solubilization and purification in an aprotic solvent

Sandhoff, K., see T. Miyatake

Sand Petersen, C., T. Herlin and V. Esmann, Effects of cytochalasin B on glycogen metabolism in phagocytizing human polymorphonuclear leukocytes

Sänger, H.L., K. Ramm, H. Domdey, H.J. Gross, K. Henco and D. Riesner, Conversion of circular viroid molecules to linear strands

99 (1979) 242

$92(1978) 365$

94 (1978) 380

97 (1979) 221

93 (1978) 73

95 (1978) 225

$92(1978) 105$

96 (1978) 335

100 (1979) 305

96 (1978) 115

98 (1979) 329

$98(1979) \quad 71$

$98(1979) \quad 76$

94 (1978) 112

94 (1978) 59

94 (1978) 315

$96(1978) 125$

97 (1979) 147

92 (1978) 207

92 (1978) 241

93 (1978) 120

95 (1978) 85

99 (1979) 67

93 (1978) 25

93 (1978) 25

98 (1979) 271

93 (1978) 43

99 (1979) 275

98 (1979) 391

93 (1978) 323

93 (1978) 247

99 (1979) 59

94 (1978) 413

98 (1979) 13

92 (1978) 333

99 (1979) 340

97 (1979) 217

98 (1979) 111

95 (1978) 107

97 (1979) 257

99 (1979) 147

$99(1979) 117$ 
San Pietro, A., see S. Lien

99 (1979) 189

Sapag-Hagar, M., see J. Puente

Sarantakis, D., J. Teichman, R. Fenichel and E. Lien, Ides-Ala ${ }^{4}$, Gly $^{2}$ J-His ${ }^{4}{ }^{4}$ D-Trp ${ }^{8}$-somatostatin: a glucagon-specific and long-acting somatostatin analog

Sari, H., S. Granon and M. Semeriva, Role of tyrosine residues in the binding of colipase to taurodeoxycholate micelles

Sarkar, S., see S.K. Jain

Sarlieve, L., see B. Zalc

Sarvas, M., K.P. Hirth, E. Fuchs and K. Simons, A precursor form of the penicillinase from Bacillus licheniformis

Satoh, K., F. Imai and K. Sato, A new glycogen phosphorylase present in the rat tissues containing the brain type isozyme - the active monomer of brain type isozyme

Sato, K., see K. Satoh

Sato, Y., T. Oda, E. Miyata and H. Saito, A ${ }^{3}$ H NMR study on biosynthesis: Evidence of hydrogen exchange at the chain-starter methyl group of griseofulvin manifested by ${ }^{2} \mathbf{H}$ incorporation from deuterium oxide in medium and from sodium acetates

Sautiere, P., see B. Laine

Savolainen, M.J., see M.A. Lehtonen

Scarpa, A., see F.J. Brinley, jr

Schaafsma, T.J., see J.L. de Wit

Schaar, P.L., see, L.D. Burtnick

Schäfer, G., see M. Schumacher

Schäfer, R. and R.M. Franklin, Structure and synthesis of a lipid-containing bacteriophage: In vitro protein synthesis directed by bacteriophage PM2

Schägger, H., see G. von Jagow

Schalch, W., see J.K. Wright

Schapendonk, A.H.C.M., see W.J. Vredenberg

Schapendonk, A.H.C.M. W.J. Vredenberg an W.J.M. Tonk, Studies on the kinetics of the 515 nm absorbance changes in chloroplasts. Evidence for the induction of a fast and a slow P515 response upon saturating light flashes

Scheer, H., see M.E. Michel-Beyerle

Scheller, F., see R. Renneberg

Scherer, E., see A.P. Steward

Scherphof, G., see J.C. Wilschut

Scherstén, T, see G. Cederblad

Schewe, T., see P. Ludwig

Schleich, T., see D.G. Bear

Schmid, B., T. Anke and H. Wolf, Action of pulvomycin and kirromycin on eukaryotic cells

Schmidlin, S., see R.W. Parish

Schmidlin, S., see R.W. Parish

Schmidlin, S., see R.W. Parish

Schmidlin, S., see R.W. Parish

Schmidt, A., A. Zilberstein, L. Shulman, P. Federman, H. Berrissi and M. Revel, Interferon action: isolation of nuclease $F$, a translation inhibitor activated by interferon-induced $\left(2^{\prime} \rightarrow 5^{\prime}\right)$ oligo-isoadenylate

Schmidt, J., M. Benecky, M. Kafina, K.L. Watters and J.T. McFarland, Resonance Raman investigation of $\beta$-(2-furyl)-acryloyl-glyceraldehyde-3-phosphate dehydrogenase

Schön, H., see I. Paetzke-Brunner

Schöpp, W., see M. Grunow

Schramm, M., see M. Laburthe

Schreiber, G., A. Gopher and M. Gutman, Evaluation of partial rate constants of competitive inhibition by analysis of nonlinear kinetics

Schreiber, G., see K. Edwards

Schroeder, C. and J. Jantschak, DNA polymerase of phage T4 antimutator mutant CB121 - a defective zinc metalloenzyme?

Schroeder, F, E.H. Goh and M. Heimberg, Investigation of the surface structure of the very low density lipoprotein using fluorescence probes

Schubert, I., see B. Kaina

99 (1979) 215

92 (1978) 153

95 (1978) 229

97 (1979) 84

92 (1978) 92

95 (1978) 76

95 (1978) 239

95 (1978) 239

98 (1979) 271

96 (1978) 291

99 (1979) 162

91 (1978) 25

92 (1978) 273

97 (1979) 166

91 (1978) 333

94 (1978) 353

91 (1978) 121

93 (1978) 317

91 (1978) 90

100 (1979) 325

100 (1979) 9

96 (1978) 349

100 (1979) 191

$98(1979) 181$

$98(1979) \quad 57$

95 (1978) 181

100 (1979) 99

96 (1978) 189

95 (1978) 366

96 (1978) 283

98 (1979) 251

99 (1979) 270

95 (1978) 257

96 (1978) 263

93 (1978) 307

94 (1978) 375

98 (1979) 41

96 (1978) 357

100 (1979) 269

$93(1978) \quad 33$

97 (1979) 233

96 (1978) 19 
Schuerch, A.R., see F. Bieri-Bonniot

96 (1978) 192

Schuldiner, S., see R. Maron

Schuldiner, S., see B.I. Kanner

Schultz, J., see J.E. Harrison

Schumacher, M., G. Schäfer, A.F. Holstein and H. Hilz, Rapid isolation of mouse Leydig cells by centrifugation in Percoll density gradients with complete retention of morphological and biochemical integrity

Schürmann, P., see J.-P. Jacquot

Schuurmans, J.J., see K.J. Hellingwerf

Schuurmans, J.J., R.P. Casey and R. Kraayenhof, Transmembrane electrical potential formation in spinach chloroplasts - investigation using a rapidly-responding extrinsic probe

Schwandt, P., W. Richter and J. Wilkening, In vitro lipolytic activity of porcine $\beta$-endorphin not mediated by an opiate receptor

Schwartz, K., P. Bouveret, J. Bercovici and B. Swynghedauw, An immunochemical difference between myosins from normal and hypertrophied rat hearts

Schwarz, L.R., R. Götz, Th. Wolff and F.J. Wiebel, Monooxygenase and glucuronyltransferase activities in short term cultures of isolated rat hepatocytes

Schwarz, Z., see U. Wienand

Schweiger, H.-G., see E. Caims

Schwenke, K.D., see P. Plietz

Schwerzmann, K., see P. Caroni

Schwerzmann, K., see H.R. Lötscher

Schyns, R. M. Mulquet and W.G. Verly, Action of rat liver AP endodeoxyribonculease on DNA treated with hydrazine or bleomycin

Scopes, P.M., see P.M. Johnson

Scozzafava, A, see 1. Bertini

Sculley, M.J., J.T. Duniec and S.W. Thorne, Reconciliation of theory and experiment on $90^{\circ}$ selective scattering spectra as a measure of intact or broken granal or agranal chloroplasts

Searle, G.F.W., see J. Barber

Sebald, W., see T. Graf

Sedliaková, M., J. Brozmanová and F. Masek, The later fate of dimers tolerated at replication in Escherchia coli B/r Hcr thy ${ }^{-}$trp $^{-}$

Sedlak, D.M., see J.A. Phillips, iii

Sedlmaier, H., W. Tischer, P. Rauschenbach and H. Simon, On the mechanism of 2-enoate reductase. Elimination of halogen hydracids from 3-halogeno-2-enoates during reduction with NADH

Seelig, J. and J.L. Browning, General features of phospholipid conformation in membranes

Segal, A.W., see M.R. Green

Scgal, A.W. and T. Meshulam, Production of superoxide by neutrophils: A reappraisal

Segal, S., see D. Gurari-Rotman

Sei, T., see N. Itoh

Seidl, D.S., H. Abreu and W.G. Jaffe, Purification of a subtilisin inhibitor from black bean seeds

Seidlitz, H., see M.E. Michel-Beyerle

Sekeris, C.E., see A. Alonso

Sekeris, C.E., see C. Flytzanis

Sekimizu, K., see Y. Nakanishi

Sela, B.-A., see Y. Levin

Selinger, Z., see M. Laburthe

Selivanova, O.M., see V.D. Vasiliev

Selman, B.R. and S. Selman-Reimer, Tentoxin-induced adenine nucleotide exchange with soluble and thylakoid membrane-bound chloroplast coupling factor 1

Selman-Reimer, S., see B.R. Selman

Selwyn, M.J., D.V. Fulton and A.P. Dawson, Inhibition of mitochondrial anion permeability by local anaesthetics

Semanza, G., see A. Klip

Semenza, G., see G. Frank

Sémériva, M., see H. Sari

Sendecki, W., see G.E. Willick

98 (1979) 237

100 (1979) 175

92 (1978) 327

91 (1978) 333

96 (1978) 243

92 (1978) 181

94 (1978) 405

100 (1979) 360

93 (1978) 137

98 (1979) 203

98 (1979) 319

96 (1978) 295

91 (1978) 227

96 (1978) 339

99 (1979) 194

93 (1978) 47

100 (1979) 141

93 (1978) 251

98 (1979) 377

92 (1978) 5

94 (1978) 218

92 (1978) 133

97 (1979) 327

100 (1979) 129

92 (1978) 41

$100(1979) \quad 23$

$100(1979) \quad 27$

94 (1978) 187

93 (1978) 343

92 (1978) 245

100 (1979) 9

93 (1978) 351

96 (1978) 201

93 (1978) 357

98 (1979) 119

98 (1979) 41

95 (1978) 273

97 (1979) 301

97 (1979) 301

96 (1978) 148

99 (1979) 91

96 (1978) 183

95 (1978) 229

$92 \quad 1978) \quad 187$ 
Sen-Maru, K., see H. Tsuge

Sentenac, A., see J. Huet

Serdyuk, I.N., G. Zaccai and A.S. Spirin, Globular conformation of some ribosomal proteins in solution

Serra, J.L., see M.J. Llama

Serrano, R., see J. Palacios

Seryakova, T.A., see S.P. Domogatsky

Severin, E.S., see B.O. Glotov

Severin, E.S., see G.A. Aphanasenko

Sha'afi, R.I., K. Williams, M.C. Wacholtz and E.L. Becker, Binding of the chemotactic synthetic peptide

$\left[{ }^{3}\right.$ H]Formyl - Nor - Leu - Leu - Phe to plasma membrane of rabbit neutrophils

Sha'afi, R.I., see R.J. Petroski

Shall, S., see C. Tsopanakis

Shapiro, R.A. and N.P. Curthoys, Characterization of the apparent rates of glutamine transport in rat renal mitochondria

Sharkov, A.V., see V.A. Shuvalov

Sharon, I., see B.I. Kanner

Sharon, I., see B.I. Kanner

Sharon, N., see C.M.T. Kieda

Sharonov, Yu.A., see A.M. Arutjunjan

Shatkin, A.J., see A. Leone

Shemyakin, M.F., A.G. Malygin and L.I. Patrushev, A study of the conditions of the first phosphodiester bond formation by $E$. coli RNA polymerase

Shemyakin, M.F., see E.L. Kapitza

Sheves, M., Y. Mazur, D. Noff and S. Edelstein, Biological deactivation of the active analogue of cholecalciferol Sheves, M., see S. Edelstein

Shiba, T., see J.-I. Nikawa

Shibatani, T., T. Kakimoto and I. Chibata, Subunit and amino acid composition of L-arginine deiminase of Pseudomonas putida

Shichida, Y., see A. Maeda

Shigekawa, M., see C.F. Louis

Shimada, H., T. Iizuka, R. Ueno and Y. Ishimura, Correlation between the quantum yields of photodissociation and $\mathrm{C}-\mathrm{O}$ stretching frequencies of carbon monoxide hemoproteins

Shimotohno, K., see S. Hidaka

Shimura, K., see H. Ishihara

Shiraiwa, Y. and S. Miyachi, Form of inorganic carbon utilized for photosynthesis across the chloroplast membrane

Shkrob, A.M., see Yu.A. Ovchinnikov

Shoham, M., J.L. Sussman, A. Yonath, J. Moult, W. Traub and A.J. Kalb (Gilboa), The effect of binding of metal ions on the three-dimensional structure of demetallized concanavalin A

Shulman, L., see A. Schmidt

Shuvalov, V.A., A.V. Klevanik, A.V. Sharkov, Ju.A. Matveetz and P.G. Krukov, Picosecond detection of BChl-800 as an intermediate electron carrier between selectivelyexcited $P_{\mathbf{8 7 0}}$ and bacteriopheophytin in Rhodospirillum rubrum reaction centers

Shuvalov, V.A., B. Ke and E. Dolan, Kinetic and spectral properties of the intermediary electron acceptor $A_{1}$ in photosystem $I$ : Subnanosecond spectroscopy

Siegenthaler, P.-A., see L.Mvé Akamba

Sies, H., see A. Wahlländer

Siess, E.A. and O.H. Wieland, Glucagon-induced stimulation of 2-oxoglutarate metabolism in mitochondria from rat liver

Siezen, R.J., Crosslinking of $\alpha$-crystallin with bisimidoesters. Evidence for polyamidine formation at pH 8 from an increase in positive charges on the polypeptide chains

Sigrist, $\mathbf{H}$. and P. Zahler, Characterization of phenylisothiocyanate as a hydrophobic membrane label

Sigrist, H., see K. Sigrist-Nelson

Sigrist-Nelson, K., H. Sigrist, H. Ariano and A. Azzi, Stoichiometric labeling and inhibition of cytochrome $c$ oxidase by phenylisothiocyanate

Silengo, L., see A. Ceccarelli

Silman, I., J.M. Lyles and E.A. Barnard, Intrinsic forms of acetylcholinesterase in skeletal muscle
93 (1978) 331

94 (1978) 28

94 (1978) 349

98 (1979) 342

91 (1978) 198

96 (1978) 207

91 (1978) 149

97 (1979) 77

91 (1978) 305

100 (1979) 161

93 (1978) 297

91 (1978) 49

91 (1978) 135

94 (1978) 245

100 (1979) 175

94 (1978) 391

95 (1978) 40

100 (1979) 103

91 (1978) 253

98 (1979) 123

96 (1978) 75

97 (1979) 241

91 (1978) 144

96 (1978) 389

92 (1978) 77

93 (1978) 61

98 (1979) 290

98 (1979) 115

99 (1979) 109

95 (1978) 207

97 (1979) 15

95 (1978) 54

95 (1978) 257

91 (1978) 135

100 (1979) 5

99 (1979) 6

97 (1979) 138

93 (1978) 301

100 (1979) 75

95 (1978) 116

95 (1978) 140

95 (1978) 140

93 (1978) 348

94 (1978) 166 
Silverstein, S., see Y. Nishioka

Sim, R.B., A. Reboul, G.J. Arlaud, C.L. Villiers and M.G. Colomb, Interaction of ${ }^{12 s}$ I-labelled complement subcomponents $\mathrm{Clr}$ and $\mathrm{Cls}$ with protease inhibitors in plasma

Simmonds, A.D., see M.J. O'Sullivan

Simmons, M., see M.J. O'Sullivan

Simon, B., see H. Kather

Simon, G., see W.F. Moo-Penn

Simon, H., see H. Sedlmaier

Simons, J., E. de Herdt, M. Kondo and H. Slegers, Membrane associated poly(A)-containing ribonucleoproteins in Artemia salina gastrula embryos

Simons, K., see M. Sarvas

Sims, T.J., see A.J. Bailey

Singer, T.P., see W.C. Kenney

Singh, A.P. and P.D. Bragg, ATP synthesis driven by a pH gradient imposed across the cell membranes of lipoic acid and unsaturated fatty acid auxotrophs of Escherichia coll

Singh, J., F.W. Flitney and J.F. Lamb, Effects of isoprenaline on contractile force and intracellular cyclic $3^{\prime}, 5^{\prime}$-nucleotide levels in the hypodynamic frog ventricle

Siniakov, M.S., see I.G. Kharitonenkov

Sinibaldi, R.M., see R.E. Law

Sinnott, M.L., Ions, ion-pairs and catalysis by the lac $Z \beta$-galactosidase of Escherichia coli

Sjöberg, B., see R. Österberg

Sjödahl, J. and S.-G. Hjalmarsson, An approach to the study of protein - drug interactions by using capillary isotachophoresis

Skinner, E.R., see C. Hay

Skotland, T., see T. Ljones

Skulachev, V.P., see Zs. Dancsházy

Skulachev, V.P., see I.E. Drobinskaya

Skutelsky, E., see D. Atlas

Sledziewski, A., see M. Barlas

Slegers, H., see J. Simons

Slegers, H., see P. Nieuwenhuysen

Slotboom, A.J., H.M. Verheij, W.C. Puijk, A.G.R. Dedieu and G.H. de Haas, High enzymatic activity of specifically iodinated bovine phospholipase $A_{2}$

Smillie, L.B., see G. Côté

Smillie, L.B., see G.P. Côté

Smith, B.E., see R.J. Rennie

Smith, D.J.H., see L.C. Packman

Smith, D.L. and T.E. Mansour, An adenosine-3', $5^{\prime}$-monophosphate activated adenylate cyclase in the slime mold Physarum polycephalum

Smith, I.C.P., see R. Walter

Smith, I.C.P., K.W. Butler, A.P. Tulloch, J.H. Davis and M. Bloom, The properties of gel state lipid in membranes of Acholeplasma laidlawii as observed by ${ }^{2} \mathbf{H}$ NMR

Smith, R.L. and F.L. Bygrave, Enrichment of Ruthenium Red-sensitive $\mathrm{Ca}^{2+}$ transport in a population of heavy mitochondria isolated from flight-muscle of Lucilia cuprina: Further evidence for its heterogeneous distribution in the inner mitochondrial membrane

Smrt, J, see S. Hynie

Smrt, J., see J. Jonák

Snary, D. and L. Hudson, Trypanosoma cruzi cell proteins: identification of one major glycoprotein

Sobel, A., see T. Heidmann

Soboll, S., see A. Wahlländer

Soboll, S., K. Werdan, M. Bozsik, M. Müller, E. Erdmann and H.W. Heldt, Distribution of metabolites between mitochondria and cytosol of cultured fibroblastoid rat heart cells

Sobue, K., S. Ichida, H. Yoshida, R. Yamazaki and S. Kakiuchi, Occurrence of $\mathrm{Ca}^{2+}$ - and modulator protein-activatable ATPase in the synaptic plasma membranes of brain

Soda, K., see T. Yagi

Sokolove, P.M. and T.V. Marsho, The effect of valinomycin on electron transport in intact spinach chloroplasts

Sokolovsky, M., see Y. Kloog

92 (1978) 283

97 (1979) 11

95 (1978) 311

95 (1978) 311

100 (1979) 145

92 (1978) 53

100 (1979) 129

91 (1978) 53

95 (1978) 76

99 (1979) 361

97 (1979) 40

98 (1979) 21

91 (1978) 269

96 (1978) 120

99 (1979) 247

94 (1978) 1

$93(1978) 115$

92 (1978) 22

91 (1978) 30

92 (1978) 81

96 (1978) 59

96 (1978) 111

95 (1978) 173

92 (1978) 195

91 (1978) 53

93 (1978) 200

92 (1978) 361

91 (1978) 237

94 (1978) 131

91 (1978) 158

$91 \quad 1978) 178$

92 (1978) 57

95 (1978) 357

$100(1979) \quad 57$

95 (1978) 303

94 (1978) 339

98 (1979) 329

100 (1979) 166

94 (1978) 397

97 (1979) 138

100 (1979) 125

99 (1979) 199

$100(1979) 81$

$100(1979) 179$

95 (1978) 331 
Sokolovsky, M., see Y. Kloog

Solheim, B.G., see P.M. Johnson

Sols, A., see P.A. Lazo

Sols, A., see M. Martinez-Pardo

Soltysiak-Pawluczuk, D. and S. Bitny-Szlachto, Activation of spleen adenylate cyclase by agents forming mixed disulfides

Soluja, A.K. and B.A. McFadden, Inhibition of ribulose bisphosphate carboxylase/oxygenase by sedoheptulose-1,7-bisphosphate

Somerharju, P., T. Kuusi, F. Paltauf and P.K.J. Kinnunen, Stereospecificity of lipoprotein lipase is an intrinsic property of the active site of the enzyme protein

Somkuti, G.A., see W.A. Bradley

Sone, N., K. Ikeba and Y. Kagawa, Inhibition of proton conduction by chemical modification of the membrane moiety of proton translocating ATPase

Sonnenbichler, J., see G. Pflugfelder

Sooranna, S.R. and E.D. Saggerson, A stable decrease in long chain fatty acyl CoA synthetase activity after treatment of rat adipocytes with adrenaline

Sooranna, S.R. and E.D. Saggerson, A decrease in diacylglycerol acyltransferase after treatment of rat adipocytes with adrenaline

Sooranna, S.R. and E.D. Saggerson, Effects of starvation and adrenaline on glycerophosphate acyltransferase and dihydroxyacetone phosphate acyltransferase activities in rat adipocytes

Sowerby, J.M., see A. Treffry

Sowerby, J.M., see A. Treffry

Spagnuolo, S., see S. Leoni

Spano, P.F., see K. Kumakura

Speakman, P.T., see B. Ahmadi

Spencer, E.M., Synthesis of cultured hepatocytes of somatomedin and its binding protein

Spencer, N., see S. Jeffery

Sperling, W., C.N. Rafferty, K.-D. Kohl and N.A. Dencher, Isomeric composition of bacteriorhodopsin under different environmental light conditions

Spiess, E., The influence of concentrating methods on electron microscopical imaging of negatively-stained $50 \mathrm{~S}$ ribosomal subunits of Escherichia coli

Spik, G., see D. Leger

Spirin, A.S., see I.N. Serdyuk

Spirin, A.S., see S.P. Domogatsky

Spona, J., Ch. Bieglmayer and R. Pirker, Progesterone receptor in the rat anterior pituitary: Transformation and nuclear translocation

Spooner, B.S., see J.L. Morgan

Staneloni, R.J., see R.A. Ugalde

Staneloni, R.J., see N.I. de Iannino

Stannard, B.S., see B.D. Weintraub

Stathopoulou, R., see M.C. Botha

Staunton, J., see A.R. Battersby

Steer, C.J., F.S. Furbish, J.A. Barranger, R.O. Brady and E.A. Jones, The uptake of agalactoglucocerebrosidase by rat hepatocytes and Kupffer cells

Stefanini, S., A. Finazzi Agrò, E. Chiancone and E. Antonini, Binding of hydrophobic compounds to apoferritin subunits. Effects on the polymerization state

Stein, O., see G. Friedman

Stein, Y., see G. Friedman

Stepanov, A.S., see S.M. Elizarov

Stermann, R. and K. Decker, Differential response of ATP and orthophosphate in cytosol and mitochondria of rat hepatocytes to treatment with $P_{i}$ and D-galactosamine

Stevens, T.H., D.F. Bocian and S.I. Chan, EPR studies of ${ }^{15} \mathrm{NO}$ ferrocy tochrome $a_{3}$ in cy tochrome $c$ oxidase

Steward, A.P., E. Scherer and P. Emmelot, Formation of relatively persistent $O^{2}$-ethylthymidine by diethylnitrosamine in rat liver DNA

Stewart, C.J., see J.-I. Nikawa

Stier, A., S.A.E. Finch and B. Bösterling, Non-lamellar structure in rabbit liver microsomal membranes:

97 (1979) 265

100 (1979) 141

98 (1979) 88

98 (1979) 99

96 (1978) 173

96 (1978) 361

96 (1978) 170

97 (1979) 81

97 (1979) 61

93 (1978) 361

92 (1978) 241

95 (1978) 85

99 (1979) 67

95 (1978) 221

100 (1979) 33

92 (1978) 63

93 (1978) 231

94 (1978) 365

99 (1979) 157

95 (1978) 323

97 (1979) 129

91 (1978) 289

93 (1978) 255

94 (1978) 349

96 (1978) 207

97 (1979) 269

93 (1978) 141

91 (1978) 209

99 (1979) 73

92 (1978) 303

96 (1978) 331

99 (1979) 297

91 (1978) 202

100 (1979) 296

100 (1979) 371

100 (1979) 371

93 (1978) 219

95 (1978) 214

97 (1979) 314

100 (1979) 191

91 (1978) 144

91 (1978) 109 
Stockley, P.G. and J.O. Thomas, A nucleosome-like particle containing an octamer of the arginine-rich histones $\mathrm{H} 3$ and $\mathrm{H} 4$

Stoesz, J.D., A.G. Redfield and D. Malinowski, Cross relaxation and spin diffusion effects on the proton NMR of biopolymers in $\mathrm{H}_{2} \mathrm{O}$ : solvent satuation and chemical exchange in superoxide dismutase

Stöffler, G., see A.R. Subramanian

Storm, C.B., see A.E.G. Cass

Strickland, M.S., see C. von Holt

Strickland, W.G., see P.F. Blackmore

Strickland, W.N., see C. von Holt

Strike, P.M., see A.S. Inglis

Strobel, G.A., see J.P. Beltran

Strom, R., C. Crifo, V. Viti, L. Guidoni and F. Podo, Variations in circular dichroism and proton NMR relaxation properties of melittin upon interaction with phospholipids

Stukacheva, E.A., see E.L. Kapitza

Subramanian, A.R. and J.N. Reeve, Synthesis of ribosomal proteins in $\lambda$ rif ${ }_{18}$ infected minicells of Escherichia coli and selective incorporation into ribosomes

Subramanian, A.R, see L. Mende

Subramanian, A.R., B. Wittmann-Liebold, A.W. Geissler, G. Stöffler and M. Giesen, Comparison of ribosomal protein $\mathrm{S} 1$ and the A-protein from Escherichia coli: Lack of structural or functional homology

Sugiura, M., M. Suzuki, E. Ohtsuka, S. Nishikawa,H. Uemura and M. Ikehara, Purification of T4 RNA ligase by $2^{\prime}, 5^{\prime}$-ADP Sepharose chromatography

Sugiyama, Y. and Y. Mukohata, Modification of one lysine by pyridoxal phosphate completely inactivates chloroplast coupling factor 1 ATPase

Summers, M.C., see A.R. Battersby

Surkov, S., see A.M. Arutjunjan

Sussman, J.L., see M. Shoham

Suttle, D.P., see D. Dottavio-Martin

Suzuki, A., see K. Kitamura

Suzuki, F., see K. Kato

Suzuki, $K$, see T. Hase

Suzuki, M., see M. Sugiura

Suzuki, M., see T. Miyatake

Suzuki, M., see K. Kitamura

Suzuki, O., see Y. Katsumata

Suzuki, Y. and M. Matsumoto, Phospholipid-dependent acid phospholipase $A_{1}$ found in cy tosol of mammalian cells

Svensson, S., see A. Lundblad

Svetlikova, S.B., see V.A. Pospelov

Svitkin, Yu.V., V.N. Lyapustin, V.A. Lashkevich and V.I. Agol, A comparative study on translation of

flavivirus and picornavirus RNAs in vitro: apparently different modes of protein synthesis

Svoboda, M., P. Robberecht and J. Christophe, Deactivation of persistently activated pancreatic adenylate cyclase. Evidence of uncoupling of hormone receptors and enzyme effector in the persistently activated state, and of the presence of two guanyl nucleotide regulatory sites

Svoboda, M,., see M. Lambert

Swift, A.D. and D.B. Crighton, The effects of certain steroid hormones on the activity of ovine hypothalamic luteinizing hormone-relcasing hormone (LH-RH)-degrading enzymes

Swynghedauw, B., see K. Schwartz

Sykes, B.D., see L. Lee

Symons, R.H., see P. Palukaitis

Szabados, Gy., see J.L. Coote

Szabo, A.G., K.R. Lynn, D.T. Krajcarski and D.M. Rayner, Tyrosinate fluorescence maxima at $345 \mathrm{~nm}$ in proteins lacking tryptophan at $\mathrm{pH} 7$

Szabolcsi, G., see E. Cseke

Szeberényi, S., see I. Horváth

91 (1978) 320

99 (1979) 357

94 (1978) 311

100 (1979) 201

100 (1979) 117

$100(1979) 201$

97 (1979) 179

$96(1978) \quad 34$

$96(1978) \quad 45$

98 (1979) 123

$95(1978) 265$

$96(1978) 395$

$99(1979) 357$

97 (1979) 73

98 (1979) 276

99 (1979) 297

95 (1978) 40

95 (1978) 54

97 (1979) 105

100 (1979) 67

99 (1979) 172

91 (1978) 315

97 (1979) 73

97 (1979) 257

$100(1979) 67$

93 (1978) 58

92 (1978) 173

97 (1979) 249

99 (1979) 123

96 (1978) 211

92 (1978) 351

99 (1979) 303

100 (1979) 110

93 (1978) 137

98 (1979) 169

92 (1978) 268

99 (1979) 255

94 (1978) 249

96 (1978) 15

98 (1979) 49

Tachikawa, E., T. Ohuchi, K. Morita, Y. Ishimura, M. Oka and F. Izumi, Activation of bovine adrenal dopamine $\beta$-hydroxylase by ADP and other nucleotides
$100(1979) 331$ 
Takahashi, K., see C. Ishikawa

Takaku, F., see S. Kitagawa

Takanami, Y., see S. Hidaka

Taki, T., see Y. Hirabayashi

Tally, M., see H. Löw

Tamaura, Y., see H. Hasebe

Tanabe, K., see Y. Kobayashi

Tanaka, A., see S. Kawamoto

Tanaka, A, see S. Kawamoto

Tanaka, C.T., see M.J.M. Alves

Tanaka, T., see S. Saheki

Tanaka, Y., see J. Redel

Tanner, M.J.A., see T. Maeda

Tao, $T_{\text {, }}$ Nanosecond fuorescence depolarization studies on actin labeled with 1,5-IAEDANS and dansyl chloride. Evidence for label flexibility

Tarantul, V.Z, see K.G. Gasaryan

Tartakovsky, B., see D. Gurari-Rotman

Tate, S.S., see E.M. Grau

Tate, W.P., see M.A. Reddington

Taylor, K.W., see I.D. Caterson

Teichman, J, see D. Sarantakis

Tempus, D., see M.E. Michel-Beyerle

Tenneson, M.E., R.F. Bilton and A.N. Mason, The degradation of lithocholic acid by Psetudononcs sp. NCIB 10590

Tenu, J.-P., see D. Vergé

Terada, H. and S. Kubota, Does hydrophobic isothiocyanate really uncouple oxidative phosphorylation in mitochondria? Uncoupling activity of a product of isothiocyanate in dimethylsulfoxide solution

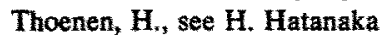

Thomas, D., see J.-L. Boitieux

Thomas, D., see M.-D. Legoy

Thomas, G., see G.K. Haselbacher

Thomas, J.O., see P.G. Stockley

Thomas, M.A.W., see J.F.Y. Hoh

Thomas, P.D. and S.K. Podder, Specificity in protein - nucleic acid interaction: solubility study on amino acid - nucleoside interaction

Thorens, S., $\mathrm{Ca}^{2+}$-ATPase and $\mathrm{Ca}$ uptake without requirement for $\mathrm{Mg}^{2+}$ in membrane fractions of vascular smooth muscle

Thornber, J.P., see R.S. Alberte

Thornber, J.P., see J.P. Markwell

Thorne, S.W., see J.M. Anderson

Thorne, S.W., see M.J. Sculley

Thomeley, R.N.F, see R.R. Eady

Thorpe, R, see D.H. Anderton

Thulin, E., see A. Cave

Thulin, E., see J. Parello

Thurnauer, M.C., M.K. Bowman and J.R. Norris, Time-resolved electron spin echo spectroscopy applied to the study of photosynthesis

Tiffer, $T$, see F.J. Brinley, jr

Thanyi, K, see 1. Horváth

Tiktopulo, E.I. and P.L. Privalov, Papain denaturation is not a two-state transition

Tilcock, C.P.S., see A.M.J. Blow

Timm, B., see L. Mende

Tischer, W., see H. Sedimaier

Titani, K., see K. Katayama

Tokunaga, $F$, see A. Maeda

Tolbert, N.E., see N.P. Hall

Toma, F., see J. Vicar $\begin{array}{rrr}99(1979) & 97 \\ 99(1979) & 275 \\ 98(1979) & 115 \\ 100(1979) & 253 \\ 91(1978) & 166 \\ 95(1978) & 295 \\ 98(1979) & 391 \\ 96(1978) & 37 \\ 97(1979) & 253 \\ 99(1979) & 81 \\ 93(1978) & 25 \\ 94(1978) & 228 \\ 98(1979) & 157 \\ & & \\ 93(1978) & 146 \\ 94(1978) & 136 \\ 94(1978) & 187 \\ 98(1979) & 91 \\ 97(1979) & 335 \\ 98(1979) & 351 \\ 92(1978) & 153 \\ 100(1979) & 9\end{array}$

91 (1978) 140

100 (1979) 265

$100(1979) \quad 37$

92 (1978) 313

93 (1978) 133

94 (1978) 335

100 (1979) 185

99 (1979) 129

97 (1979) 330

$96(1978) \quad 90$

98 (1979) 177

91 (1978) 126

99 (1979) 11

92 (1978) 227

98 (1979) 377

95 (1978) 211

$96(1978) 159$

$100(1979) 148$

100 (1979) 153

100 (1979) 309

91 (1978) 25

$98(1979) \quad 49$

91 (1978) 57

94 (1978) 305

96 (1978) 395

$100(1979) 129$

95 (1978) 157

92 (1978) 77

96 (1978) 167

97 (1979) 275 
Tomasi, M., A. Battistini, C. Ausiello, L.G. Roda and G. D'Agnolo, The role of environmental parameters on the stability of cholera toxin functional regions

Tonk, W.J.M., see A.H.C.M. Schapendonk

Tordera, V., see D. Leger

Toriyama, S., I. Yano, M. Masui, M. Kusunose and E. Kusunose, Separation of $\mathrm{C}_{50-{ }_{00}}$ and $\mathrm{C}_{70}-8 ;$ mycolic acid molecular species and their changes by growth temperatures in Mycobacterium phlei

Torres, M., C. Auclair and J. Hakim, NADH oxidation and oxygen reductions by the granule-rich fraction isolated from human polymorphonuclear blood cells

Trabucchi, M., see K. Kumakura

Tranum-Jensen, J., see S. Bhakdi

Trapman, J., A systematic study of interferon production by mouse L-929 cells induced with poly (I) poly (C) and DEAE-dextran

Trasch, H. and E. Bäuerlein, The action of lipophilic alkylamines on beef heart mitochondria: Evidence for the inhibition of proton translocation linked to electron transport

Traub, W., Molecular assembly in collagen

Traub, W., see M. Shoham

Travers, A.A., ppApp alters transcriptional selectivity of Escherichia coli RNA polymerase

Treffry, A., J.M. Sowerby and P.M. Harrison, Variable stoichiometry of Fe(II)-oxidation in ferritin

Treffry, A., J.M. Sowerby and P.M. Harrison, Oxidant specificity in ferritin formation

Treiman, M., J. Pødenphant, T. Særmark and E. Bock, Inhibition by $\mathrm{Ca}^{2+}$ of the adenosine $3^{\prime}: 5^{\prime}$-cyclic monophosphate-stimulated phosphorylation of proteins in membranes from ox neurohypophyseal secretosomes

Treimer, J.F. and M.H. Zenk, Strictosidine synthase from cell cultures of Apocynaceae plants

Tritsch, D., see J. Reinbolt

Trumpower, B.L. and C.A. Edwards, Identification of oxidation factor as a reconstitutively active form of the iron - sulfur protein of the cytochrome $b-c_{1}$ segment of the respiratory chain

Trush, M.A., see M.E. Wilson

Tsopanakis, C., J.C. Leer, O.F. Nielsen, E. Gocke, S. Shall and O. Westergaard, Poly(ADP-ribose) metabolizing enzymes in nuclei and nucleoli of Tetrahymena pyriformis

Tsuge, H., K. Sen-Maru and K. Ohashi, Immobilization of yeast pyridoxamine (pyridoxine) 5 '-phosphate oxidase by organomercurial agarose

Tsuji, H., see H. Kuthan

Tsuji, K. and K. Rosenheck, The low pH species of bacteriorhodopsin: Structure and proton pump activity

Tsujimoto, H.Y., see T. Hiyama

Tulloch, A.P., see I.C.P. Smith

Tumanova, L.G., see A.T. Gudkov

Turc, J.M., see D. Ricquier

Turco, E., see A. Ceccarelli

Turini, P., see M.T. Costa

Turk, V., see M. Kopitar

Turner, A.J., see A.G.M. Pearson

Twardowski, T., see A. Joachimiak

Ueda, M., see S. Kawamoto

Ueland, P.M., see J. Sæbø

Uemura, H., see M. Sugiura

Ueno, R, see H. Shimada

Ugalde, R.A., R.J. Staneloni and L.F. Leloir, Action of glycosidases on the saccharide moiety of the glucosecontaining dolichyl diphosphate oligosaccharide



Ujházy, V., see J. Kolarov

Ullich, V., see H. Kuthan

Uistrup, J., see J. Jortner

Umeda, Y., see K. Kato

Umyarov, A.M., A.G. Voloshin, T.N. Bolshakova and V.N. Gershanovitch, Effect of ptsI and pts $H$ genes dosage on manifestation of glucose catabolite repression of $\beta$-galactosidase synthesis in Escherichia coli $\mathrm{K} 12$

Underwood, C., see J.M. Gould

94 (1978) 253

100 (1979) 325

93 (1978) 255

95 (1978) 111

97 (1979) 50

93 (1978) 231

99 (1979) 15

98 (1979) 107

97 (1979) 133

92 (1978) 114

95 (1978) 54

94 (1978) 345

95 (1978) 221

100 (1979) 33

97 (1979) 147

97 (1979) 159

$91(1978) 297$

100 (1979) 13

94 (1978) 387

$93(1978) 297$

93 (1978) 331

91 (1978) 343

98 (1979) 368

98 (1979) 381

100 (1979) 57

93 (1978) 215

99 (1979) 203

93 (1978) 348

94 (1978) 112

91 (1978) 355

98 (1979) 96

93 (1978) 51

96 (1978) 37

96 (1978) 125

97 (1979) 73

98 (1979) 290

91 (1978) 209

91 (1978) 222

96 (1978) 373

91 (1978) 343

99 (1979) 1

99 (1979) 172

96 (1978) 31

95 (1978) 197 
Undheim, K., see M. Gacek

Unger, R.H., see J.M. Conlon

Urbanelli, S., see L. Avigliano

Urios, P., N. Cittanova and M.-F. Jayle, Immunoassay of the human chorionic gonadotrophin using fluorescence polarization

Urry, D.W., see R.S. Bhatnagar

Usui, T., see Y. Kobayashi

Utermann, G. and U. Beisiegel, Charge-shift electrophoresis of apolipoproteins from normal humans and patients with Tangier disease

Uvnäs-Wallensten, K., see S. Efendić

Uyemura, K., see K. Kitamura

Vaček, M., see W.F. Moo-Penn

Vaes, G., see G. Huybrechts-Godin

Vale, W., see J.M. Conlon

Valeri, C.R., see J.L. Costa

Vallari, R.C., see R. Pietruszko

Van Alphen, W., see B. Lugtenberg

Vanaman, T.C., see P. Cohen

Van Beeumen, J., J. van Damme and J. de Ley, PTH-amino acid analysis by micro high-performance liquid chromatography (MHPLC)

Van Beveren, C.P., see A. de Waard

Van Boxtel, R., see B. Lugtenberg

Van Brederode, J., see J. Kamsteeg

Van Damme, J., see J. van Beeumen

Vandenbunder, B., see M. Dreyfus

Van den Eijnden, D.H., see J.F. Codington

Van der Laken, K., H. Bakker-Steeneveld and P. van Knippenberg, Polyuridylic acid-dependent binding of formylmethionyl-tRNA to Escherichia coli ribosomes and incorporation of formylmethionine into polyphenylalanine

Van der Molen, H.J., see E. Mulder

Van der Ploeg, K.R., see H.J. Grande

Van Dyke, K., see M.E. Wilson

Van Ginkel, G. and J.S. Brown, Endogenous catalase and superoxide dismutase activities in photosynthetic membranes

Van Hinsbergh, V.W.M., J.H. Veerkamp and J.G.E.M. Zuurveld, Role of carnitine in leucine oxidation by mitochondria of rat muscle

Van Knippenberg, P., see K. van der Laken

Van Nigtevecht, G., see J. Kamsteeg

Van Rietschoten, J., see C. Ronin

Van Ruijven-Vermeer, I.A.M., W. Nieuwenhuizen and W.J. Nooijen, Ca binding of rat fibrinogen and fibrin(ogen) degradation products

Van Venrooij, W.J., see F.A.M. Asselbergs

Van Vloten-Doting, L., see L. Neeleman

Varas, M.A., see J. Puente

Váradi, A., see E. Cseke

Vargas, A., see R. Muñoz-Clares

Vasak, M., see A. Galdes

Vasiliev, V.D., O.M. Selivanova and V.E. Koteliansky, Specific selfpacking of the ribosomal 16 S RNA

Vazquez, D., see C. Bernabeu

Vecchione, J.J., see J.L. Costa

Veerkamp, J.H., see V.W.M. van Hinsberg

Venardi, G., see F. Marmocchi

Venturoli, G., see B.A. Melandri

Venyaminov, S.Yu., see A.T. Gudkov

Veres-Molnár, Z., see J. Adamkiewicz

Vergé, D., J.-P. Tcnu and M.Arrio-Dupont, Inorganic phosphate binding to apoaspartate aminotransferase
98 (1979) 355

94 (1978) 327

$100(1979) 318$

94 (1978) 54

95 (1978) 61

98 (1979) 391

97 (1979) 245

92 (1978) 33

100 (1979) 67

92 (1978) 53

91 (1978) 242

94 (1978) 327

99 (1979) 141

92 (1978) 89

96 (1978) 99

92 (1978) 287

93 (1978) 373

96 (1978) 106

96 (1978) 99

91 (1978) 281

93 (1978) 373

95 (1978) 185

99 (1979) 70

100 (1979) 230

97 (1979) 260

95 (1978) 352

94 (1978) 387

94 (1978) 284

92 (1978) 100

100 (1979) 230

91 (1978) 281

96 (1978) 179

93 (1978) 177

94 (1978) 195

95 (1978) 103

99 (1979) 215

96 (1978) 15

99 (1979) 340

92 (1978) 17

95 (1978) 273

99 (1979) 251

99 (1979) 141

92 (1978) 100

94 (1978) 109

95 (1978) 130

93 (1978) 215

94 (1978) 199

100 (1979) 265 
Verheij, H.M., see A.J. Slotboom

Verhoef, C., see B. Lugtenberg

Verly, W.G., see R. Schyns

Vermond, A., see W. Nieuwenhuizen

Versée, V. and A.O. Barel, Binding specificity of estrogens and norandrogens to rat $\alpha$-fetoprotein (AFP)

Vičar, J., E. Abillon, F. Toma, F. Piriou, K. Lintner, K. Bláha, P. Fromageot and S. Fermandjian, The two conformations of TRH in solution

Vidal, J., see J.-P. Jacquot

Vignais, P.M., see M.F. Henry

Vignais, P.V., see F. Boulay

Vigny, M., see S. Carson

Viktorova, L.N., B.A. Klyashchitskii and E.V. Ramensky, Biospecific affinity chromatography of smooth muscle glycogen phosphorylase $b$ on glycogen-Sepharose

Villiers, C.L., see R.B. Sim

Vinkler, C., M. Avron and P.D. Boyer, Initial formation of ATP in photophosphorylation does not require a proton gradient

Virmaux, N., see J.E. Hesketh

Viti, V., see R. Strom

Vlasik, T.N., see S.P. Domogatsky

Vlassov, V.V., A.T. Pusyriov and H.J. Gross, Evidence from chemical modification for an unusual tertiary structure of the $T \psi C$ loop in rabbit liver tRNA Val

Vlassov, V.V. and S.N. Khodyreva, Equilibrium screening-dialysis investigation of the nucleotide sequences in the tRNA ${ }^{\text {Phe }}$ recognized by phenylalanyl-tRNA synthetase (Escherichia coli)

Vliegenthart, J.F.G., see D. Leger

Vogel, C.W., see W. Weber

Vogel, Z. and M. Altstein, The effect of puromycin on the biological activity of Leu-enkephalin

Voloshin, A.G., see A.M. Umyarov

Volsky, D.J. and A. Loyter, An efficient method for reassembly of fusogenic Sendai virus envelopes after solubilization of intact virions with Triton X-100

Von Borstel, R.W., see L.M. Hall

Von der Haar, F., The ligand-induced solubility shift in salting out chromatography; a new affinity technique, demonstrated with phenylalanyl-and isoleucyl-tRNA synthetase from baker's yeast

Von der Mark, H. and K. von der Mark, Isolation and characterization of collagen A and B chains from chick embryos

Von der Mark, K., see H. von der Mark

Vonderschmitt, D.J., see E. Bisse

Von Holt, C., W.N. Strickland, W.F. Brandt and M.S. Strickland, More histone structures

Von Jagow, G., H. Schägger, W.D. Engel, W. Machleidt, I. Machleidt and H.J. Kolb, Beef heart complex III: isolation and characterization of cytochrome $b$

Von Mickwitz, C.-U., G. Burckhardt, H. Fenske and Ch. Zimmer, DNP double fibers induced by DNA - H1 histone interaction

Vorob'ev, V.I., see V.A. Pospelov

Vredenberg, W.J. and A.H.C.M. Schapendonk, Evidence for a light-induced blue band shift of part of the P515 pigment pool in intact chloroplasts

Vredenberg, W.J., see A.H.C.M. Schapendonk

Vuust, J., see K. Poulsen

Wacholtz, M.C., see R.I. Sha'afi

Wacker, H., see G. Frank

Wada, K., see T. Hase

Waelti, E., see J. Hagmann

Wahlländer, A., S. Soboll, H. Sies, I. Linke and M. Müller, Hepatic mitochondrial and cytosolic glutathione content and the subcellular distribution of $\mathrm{GSH} / \mathrm{S}$-transferases

Wahnbaeck-Spencer, R., see R.R. Henke

Wajnberg, E., P.C. Ribeiro, O.R. Nascimento and G. Bemski, Conformational change in spin-labelled myoglobin; electron paramagnetic resonance in solution and powdered samples

Wakabayashi, S., see T. Hase
92 (1978) 361

$96(1978) 99$

93 (1978) 47

98 (1979) 257

96 (1978) 155

97 (1979) 275

96 (1978) 243

100 (1979) 41

98 (1979) 161

97 (1979) 348

91 (1978) 194

97 (1979) 111

96 (1978) 129

94 (1978) 357

966 (1978) 45

96 (1978) 207

94 (1978) 157

96 (1978) 95

93 (1978) 255

99 (1979) 62

98 (1979) 44

96 (1978) 31

92 (1978) 190

95 (1978) 243

94 (1978) 371

99 (1979) 101

99 (1979) 101

93 (1978) 102

100 (1979) 201

91 (1978) 121

98 (1979) 324

99 (1979) 123

91 (1978) 90

100 (1979) 325

98 (1979) 135

91 (1978) 305

96 (1978) 183

96 (1978) 41

97 (1979) 230

97 (1979) 138

99 (1979) 113

91 (1978) 257

91 (1978) 315 
Wakabayashi, S., see T. Hase

96 (1978) 41

Waldron, J.C., see J.M. Anderson

Waldvogel, M., see J. Zapf

Waley, S.G., see V. Knott-Hunziker

Walker, D.A., see S.P. Robinson

Walker, J.M., G.H. Goodwin and E.W. Johns, The primary structure of the nucleosome-associated chromosomal protein HMG 14

Walker, K.B. and B.W. Wilson, Regulation of acetylcholinesterase in cultured chick embryo spinal cord neurons

Walker, M.D., A.M. Kaye and B.R. Fridlender, Age-dependent stimulation by estradiol 17- $\beta$ of DNA polymerase $\alpha$ in immature rat uterus

Walker, M.D., V. Negreanu, I. Gozes and A.M. Kaye, Identification of the 'estrogen-induced protein' in uterus and brain of untreated immature rats

Wallis, O.C., A.W. Johnson and M.F. Lappert, Studies on the subunit structure of the adenosylcobalamindependent enzyme ethanolamine ammonia-lyase

Walsh, K.A., see J.D. Londsdale-Eccles

Walters, R., R. Deslauriers and I.C.P. Smith, Aggregation of Pro - Leu - Gly - $\mathrm{NH}_{2}$ in aqueous solution

Watanabe, $\mathrm{K}$, see C. Ishikawa

Watson, B.D., see J.E. Harrison

Watters, K.L., see J. Schmidt

Watts, C. and K.P. Wheeler, Partial separation of a sodium-dependent transport system for amino acids in avian erythrocyte membranes

Wauters, M., A.M. Michelson and R.R. Crichton, Studies on the mechanism of ferritin formation: superoxide dismutase, rapid kinetics and $\mathrm{Cr}^{3+}$ inhibition

Weber, W., C.W. Vogel and H. Hilz, A new cAMP affinity matrix for the rapid purification of protein kinase regulatory subunits

Weekes, G.A., see V.K. Moudgil

Weibel, M., see R.W. Parish

Weidoff, P.M., jr, M.G. McNamee and B.W. Wilson, Modulation of cholinergic proteins and RNA by ouabain in chick muscle cultures

Weigele, J.B. and R.L. Barchi, Analysis of saxitoxin binding in isolated rat synaptosomes using a rapid filtration assay

Weigele, J.B. and R.L. Barchi, Saxitoxin binding to the mammalian sodium channel: competition by monovalent and divalent cations

Weiler, I., see J. Hagmann

Weintraub, B.D. and B.S. Stannard, Precursor - product relationships in the biosynthesis and secretion of thyrotropin and its subunits by mouse thyrotropic tumor cells

Weisman-Shomer, P., see A. Kaftory

Werdan, K., see S. Soboll

Werringloer, J, see H. Kuthan

Weser, U., M. Younes, H.-J. Hartmann and S. Zienau, X-ray photoelectron spectrometric aspects of the copper chromophore in plastocyanin

Westergaard, O., see C. Tsopanakis

Westerhoff, H.V., see K.J. Hellingwerf

Westerman, J., see R.L. Jackson

Westermann, P., W. Heumann, U.-A. Bommer, H. Bielka, O. Nygard and T. Hultin, Crosslinking of initiation factor eIF-2 to proteins of the small subunit of rat liver ribosomes

Westermann, P., see E.T. Palva

Wheeler, K.P., see C. Watts

Whetstone, R., see D.B. Knaff

White, T.J., see M.W. Hsiang

Whittaker, A.D., see B.K. Park

Whitton, P.D., L.M. Rodrigues and D.A. Hems, Stimulation by acetate of gluconeogenesis in hepatocyte suspensions

Wicklmayr, M., see G. Dietze

Wicklmayr, M., G. Dietze, L. Mayer, I. Böttger and J. Grunst, Evidence for an involvement of kinin liberation in the priming action of insulin on glucose uptake into skeletal muscle

92 (1978) 227

94 (1978) 43

99 (1979) 59

97 (1979) 296

$100(1979) 394$

$93(1978) \quad 81$

$92(1978) 25$

98 (1979) 187

97 (1979) 196

100 (1979) 157

95 (1978) 357

99 (1979) 97

92 (1978) 329

96 (1978) 263

94 (1978) 241

91 (1978) 276

99 (1979) 62

94 (1978) 324

96 (1978) 283

100 (1979) 389

91 (1978) 310

95 (1978) 49

97 (1979) 230

92 (1978) 303

99 (1979) 265

100 (1979) 125

91 (1978) 343

97 (1979) 311

93 (1978) 297

92 (1978) 181

94 (1978) 38

97 (1979) 101

99 (1979) 77

94 (1978) 241

99 (1979) 283

92 (1978) 97

91 (1978) 273

98 (1979) 85

92 (1978) 294

98 (1979) 61 
Wiebel, F.J., see L.R. Schwarz

Wieczorek, L. and K. Altendorf, Potassium transport in Escherichia coli: Evidence for a $\mathbf{K}^{+}$-transport adenosine-5'-triphosphatase

Wieland, F. and H. Engeser, A rapid and highly resolving method for protein subunit separation

Wieland, O.H., see E.A. Siess

Wieland, O.H., see I. Paetzke-Brunner

Wieland, O.H., see R. Dolhofer

Wieland, Th., see J.-I. Nikawa

Wieland, Th., see H.P. Blaschkowski

Wielburski, A. and B.D. Nelson, Effects of $\mathrm{K}^{+}$diffusion potentials on duroquinol-cytochrome $c$ reductase activity catalyzed by complex III incorporated into liposomes

Wienand, U., Z. Schwarz and G. Feix, Electrophoretic elution of nucleic acids from gels adapted for subsequent biological tests: Application for analysis of mRNAs from maize endosperm

Wieser, W., The initial stage of anaerobic metabolism in the snail, Helix pomatia

Wiewiórowski, M., see A. Joachimiak

Wikström, M.K.F. and K. Krab, Cytochrome $c$ oxidase is a proton pump

Wikström, M.K.F., see K.E.O. Åkerman

Wildner, G.F. and J. Henkel, Differential reactivation of ribulose 1,5-bisphosphate oxygenase with low carboxylase activity by $\mathrm{Mn}^{2+}$

Wilkening, J., see P. Schwandt

Williams, A.J. and C.H. Fry, Calcium - proton exchange in cardiac and liver mitochondria

Williams, K., see R.I. Sha'afi

Williams, R.E., see G.E. Willick

Willick, G.E., R.E. Williams, A.T. Matheson and W. Sendecki, Salt stabilization of a S RNA protein complex from an extreme halophile, Halobacterium cutirubrum

Wilschut, J.C., J. Regts and G. Scherphof, Action of phospholipase A2 on phospholipid vesicles: Preservation of the membrane permeability barrier during asymmetric bilayer degradation

Wilson, B.W, see K.B. Walker

Wilson, B.W., see Weidoff, P.M., jr

Wilson, D.B., see B. Bloj

Wilson, K.G., see W.R. Mills

Wilson, M.E., M.A. Trush, K. van Dyke and W. Neal, Induction of chemiluminescence in human polymorphonuclear leukocytes by the calcium ionophore A23187

Wilton, D.C., see A.G. Lee

Winchester, B.G., see L.J. Burditt

Winkelhake, J.L., see J.A. Kulkoski

Winkelmann, G., Evidence for stereospecific uptake of iron chelates in fungi

Winterbourne, C.C., J.K. French and R.F.C. Claridge, Superoxide dismutase as an inhibitor of reactions of semiquinone radicals

Wirtz, K.W.A., see R.L. Jackson

Wisdom, G.B., see M.I. Halliday

Wiseman, R.L., see B. Frangione

Wisner, J.R., jr, see S.I. Fox

Wittmann, H.G., see T. Morinaga

Wittmann-Liebold, B., see T. Morinaga

Wittmann-Liebold, B., see J. Reinbolt

Wittmann-Liebold, B., see J.Y. Chang

Wittmann-Liebold, B. and B. Greuer, The primary structure of protein S5 from the small subunit of the Escherichia coli ribosome

Wittmann-Liebold, B., see T. Itoh

Wittmann-Liebold, B., see T. Itoh

Wittmann-Liebold, B., see A.R. Subramanian

Wlodawer, P. and S. Hammarström, Some properties of prostacyclin synthase from pig aorta

Wojtczak, L., see K. Bogucka

Woldringh, C.L., see A. Zaritsky

Wolf, D.H. and C. Ehmann, Carboxypeptidase S from yeast: regulation of its activity during vegetative growth and differentiation

$98(1979) 203$

98 (1979) 233

$100(1979) \quad 90$

93 (1978) 301

93 (1978) 307

$100(1979) 133$

91 (1978) 144

98 (1979) 81

$93(1978) 69$

98 (1979) 319

95 (1978) 375

93 (1978) 51

91 (1978) 8

97 (1979) 283

$91(1978) 99$

100 (1979) 360

97 (1979) 288

91 (1978) 305

92 (1978) 187

92 (1978) 187

98 (1979) 181

93 (1978) 81

$100(1979) 389$

96 (1978) 87

92 (1978) 129

94 (1978) 387

94 (1978) 171

91 (1978) 186

99 (1979) 183

97 (1979) 43

94 (1978) 269

94 (1978) 38

96 (1978) 298

96 (1978) 381

98 (1979) 192

91 (1978) 74

91 (1978) 74

91 (1978) 297

93 (1978) 205

95 (1978) 91

96 (1978) 392

96 (1978) 399

99 (1979) 357

97 (1979) 32

100 (1979) 301

98 (1979) 29

91 (1978) 59 
Wolf, D.H. and C. Ehmann, Isolation of yeast mutants lacking proteinase B activity

Wolf, H. see B. Schmid

Wolff, C.H.J., see K.E.O. Akerman

Wolff, J.A., see W.F. Moo-penn

Wolff, Th., see L.R. Schwarz

Wong, D. and Govindjee, Antagonistic effects of mono- and divalent cations on polarization of chlorophyll fluorescence in thylakoids and changes in excitation energy transfer

Wong, M., M.E. Baycr and S. Litwin, Virus - cell interaction: prediction of the time course of obscrvable effects from virus interaction at cell injection sites, and mechanisms leading to attachment

Wood, P.M., Periplasmic location of the terminal reductase in nitrite respiration

Wood, P.M., A chemiosmotic model for sulphate respiration

Work, T.S., see J.L. Coote

Wraight, C.A., Iron - quinone interactions in the electron acceptor region of bacterial photosynthetic reaction centers

Wreschner, D.H., The role of ribosomal RNA in protein synthesis. Inhibition of translation by reticulocyte 5 S ribosomal RNA

Wreschner, D.H., Reticulocyte $5 \mathrm{~S}$ ribosomal RNA inhibition of cell-free synthesis. Novel response in ribosomal behaviour

Wrigglesworth, J.M. and P. Nicholls, Steady state spectra of cytochrome $c$ oxidase in reconstituted vesicles

Wright, J.K., W. Schalch, L.S. Rodkey and D.G. Braun, High affinity anti-carbohydrate antibodies identified in anti-A-variant streptococcal antisera

$\mathrm{Wu}$, N.-C. and R.M. Zucker, Mouse fetal hemoglobin synthesis in murine erythroleukemic cells

Wüthrich, K., see J. Lauterwein

Wykes, A., see K. Edwards

Wyler, T., see U. Gubler

Wyman, J., see J.-E. Norne

Yaffe, D., see D. Atlas

Yagi, K., see W.C. Kenney

Yagi,T., T. Kagamiyama, K. Motosugi, M. Nozaki and K. Soda, Crystallization and properties of aspartate aminotransferase from Escherichia coli $\mathrm{B}$

Yamada, A., H. Kaneko, K. Akasaka and H. Hatono, Detecting conformational heterogeneity in the DNA backbone by "${ }^{31} \mathrm{P}$ NMR

Yamada, T., see S. Kawamoto

Yamada, T., see T. Miyatake

Yamamura, M., see S. Kawamoto

Yamashina, I., see A. Lundblad

Yamashita, K., see M.-L. Aitio

Yamazaki, R., see K. Sobue

Yamazaki, S., see H. Hasebe

Yamazaki, T., see J.F. Codington

Yano, I., see S. Toriyama

Yasutake, A., K. Miyazaki, H. Aoyagi, T. Kato and N. Izumiya, Hydrolysis of cyclic depsidipeptides by trypsin or chymotrypsin

Yavin, E. and S. Harel, Muscarinic binding sites in the developing rabbit brain: Regional distribution and ontogenesis in the prenatal and early neonatal ccrebcllum

Yeoh, G.P.S., see J.F.Y. Hoh

Yonath, A., see M. Shoham

Younes, M., see U. Weser

Yoshida, H., see K. Sobue

Yoshida, T., see M. Noguchi

Yoshizawa, T., see A. Maeda

Yount, R.G., see K.-S. Boos

Yu, F., S. Ichihara and S. Mizushima, A major outer membrane protein (O-8) of Escherichia coli $\mathrm{K}-12$ exists as a trimer in sodium dodecyl sulfate solution

92 (1978) 121

96 (1978) 189

100 (1979) 291

92 (1978) 53

98 (1979) 203

97 (1979) 373

95 (1978) 26

92 (1978) 214

95 (1978) 12

99 (1979) 255

93 (1978) 283

94 (1978) 139

94 (1978) 145

91 (1978) 190

93 (1978) 317

99 (1979) 299

93 (1978) 181

100 (1979) 269

100 (1979) 347

94 (1978) 410

95 (1978) 173

97 (1979) 40

100 (1979) 81

93 (1978) 16

97 (1979) 253

97 (1979) 257

96 (1978) 37

97 (1979) 249

93 (1978) 29

99 (1979) 199

95 (1978) 295

99 (1979) 70

95 (1978) 111

100 (1979) 241

97 (1979) 151

97 (1979) 330

95 (1978) 54

97 (1979) 311

99 (1979) 199

98 (1979) 281

92 (1978) 77

91 (1978) 285

100 (1979) 71

94 (1978) 349

Zaccai, G., see I.N. Serdyuk 
Zahler, P., see H. Sigrist

Zahn, R.K., see W.E.G. Müller

Zalc, B., J.J. Helwig, M.S. Ghandour and L. Sarlieve, Sulfatide in the kidney: how is this lipid involved in sodium chloride tranport?

Zanotti, A., see G.F. Azzone

Zanotti, A., see G.F. Azzone

Zapf, J., M. Waldvogel, P. Zumstein and E.R. Froesch, Increased sensitivity to epinephrine of the cyclic AMP protein kinase system in adipose tissue of diabetic rats

Zappia, V., R. Porta, M. Carteni-Farina, M. De Rosa and A. Gambacorta, Polyamine distribution in eukaryotes: occurrence of sym-nor-spermidine and sym-nor-spermine in arthropods

Zaritsky, A., C.L. Woldringh and D. Mirelman, Constant peptidoglycan density in the sacculus of Escherichia coli $\mathrm{B} / \mathrm{r}$ growing at different rates

Zaslavsky, B.Yu., L.M. Miheeva, N.M. Mestechkina, V.M. Pogorelov and S.V. Rogozhin, General rule of partition behaviour of cells and soluble substances in aqueous two-phase polymeric systems

Zenk, M.H., see J.F. Treimer

Zeppezauer, E., see E. Bignetti

Zickler, A., see P. Gräber

Zienau, S., see U. Weser

Zilberstein, A., see A. Schmidt

Zillig, W., see H. Heumann

Zilversmit, D.B., see B. Bloj

Zimmer, Ch., see C.-U. von Mickwitz

Zimmer, G., L. Mainka and G. Ohlenschläger, Oligomycin-sensitive ATPase from beef heart mitochondria:

Reaction with 2-mercaptopropionylglycine

Zirwer, D., see P. Plietz

Zonneveld, A.J., see H. Jansen

Zuber, H., see G. Frank

Zucker, R.M., see N.-C. Wu

Zumstein, P., see J. Zapf

Zuurveld, J.G.E.M., see V.W.M. van Hinsbergh

Zvonar, T., see M. Kopitar

Zweibaum, A., see M. Laburthe

Zyznar, E., see J.M. Conlon

95 (1978) 116

94 (1978) 47

92 (1978) 92

96 (1978) 135

96 (1978) 141

94 (1978) 43

94 (1978) 161

$98(1979) \quad 29$

94 (1978) 77

97 (1979) 159

100 (1979) 17

96 (1978) 233

97 (1979) 311

95 (1978) 257

91 (1978) 351

96 (1978) 87

98 (1979) 324

94 (1978) 233

91 (1978) 227

98 (1979) 299

96 (1978) 183

99 (1979) 299

94 (1978) 43

92 (1978) 100

91 (1978) 355

98 (1979) 41

94 (1978) 327 